Florida International University FIU Digital Commons

6-14-2016

\title{
The Association of Real Earnings Management with: Enterprise Resource Planning Systems, Audit Effort, and Future Financial Performance
}

Angel Arturo Pacheco Paredes

Florida International University, apach010@fiu.edu

DOI: 10.25148 /etd.FIDC000701

Follow this and additional works at: https://digitalcommons.fiu.edu/etd

Part of the Accounting Commons

\section{Recommended Citation}

Pacheco Paredes, Angel Arturo, "The Association of Real Earnings Management with: Enterprise Resource Planning Systems, Audit Effort, and Future Financial Performance" (2016). FIU Electronic Theses and Dissertations. 2624.

https://digitalcommons.fiu.edu/etd/2624 


\title{
FLORIDA INTERNATIONAL UNIVERSITY \\ Miami, Florida
}

\section{THE ASSOCIATION OF REAL EARNINGS MANAGEMENT WITH: ENTERPRISE RESOURCE PLANNING SYSTEMS, AUDIT EFFORT, AND FUTURE FINANCIAL PERFORMANCE}

\author{
A dissertation submitted in partial fulfillment of \\ the requirements for the degree of \\ DOCTOR OF PHILOSOPHY \\ in \\ BUSINESS ADMINISTRATION \\ by \\ Angel Arturo Pacheco Paredes
}

2016 
To: Acting Dean Jose M. Aldrich

College of Business

This dissertation, written by Angel Arturo Pacheco Paredes, and entitled The Association of Real Earnings Management with: Enterprise Resource Planning Systems, Audit Effort, and Future Financial Performance, having been approved in respect to style and intellectual content, is referred to you for judgment.

We have read this dissertation and recommend that it be approved.

Kannan Raghunandan

Dasaratha Rama

Suchismita Mishra

Clark Wheatley, Major Professor

Date of Defense: June 14, 2016

The dissertation of Angel Arturo Pacheco Paredes is approved.

Acting Dean Jose M. Aldrich
College of Business

Andrés G. Gil

Vice President for Research and Economic Development and Dean of the University Graduate School

Florida International University, 2016 


\section{DEDICATION}

I would like to dedicate this dissertation, an exploration into real earnings management, to those wonderful people who gave me support while I was investigating this phenomenon. Foremost amongst those are my parents, Jose Guillermo Pacheco and Maria Teresa Paredes, my siblings G. Memo and Yadira Pacheco Paredes, and all friends made at Florida International University. If not for their support I genuinely believe this labor would have been harder. With their support, it was a labor of love and easily the time of my life. I also desire to dedicate this dissertation to the one person I trusted to guide me through the process. My mentor \& trusted friend, my alma gemela, he helped me adapt to South Florida, to life as a $\mathrm{PhD}$ student, and also to life as a professor. Without his daily help and guidance my experience would have palled, but he furnished support, astute advice and guidance. I am yet sure, I will miss most, my time together with Clark Wheatley. 


\section{ACKNOWLEDGMENTS}

I would like to gratefully acknowledge the members of my committee for their helpful comments and suggestions: Dr. Kannan Raghunandan, Dr. Dasaratha Rama and Dr. Suchismita Mishra. Finally, I would like to thank my major professor Dr. Clark Wheatley for his unwaivering support. 


\begin{abstract}
OF THE DISSERTATION
THE ASSOCIATION OF REAL EARNINGS MANAGEMENT WITH: ENTERPRISE RESOURCE PLANNING SYSTEMS, AUDIT EFFORT, AND FUTURE FINANCIAL PERFORMANCE
\end{abstract}

by

Angel Arturo Pacheco Paredes

Florida International University, 2016

Miami, Florida

Professor Clark Wheatley, Major Professor

Emerging research on real earnings management [REM] has expressed the concern that firms deviating from normal business practices may endure a negative impact on future cash flows and performance. This dissertation (in three essays) investigates the phenomenon of real earnings management in its association with: 1) enterprise resource planning systems [ERPs]; 2) audit report lags [ARLs]; and 3) future firm performance. In the first investigation I hypothesize that the increased monitoring associated with the implementation of an ERP will result in a decline in REM. In the second investigation I hypothesize that higher levels of REM will evoke greater auditor scrutiny and be associated with longer ARLs. In the third investigation I hypothesize that managerial actions that would ordinarily be classified as REM: reductions in discretionary expenditures or overproduction, are not REM but indicative of enhanced efficiencies when found in concert with prior period restructurings or expected future sales growth respectively. In each of the three investigations, my hypotheses are confirmed. 


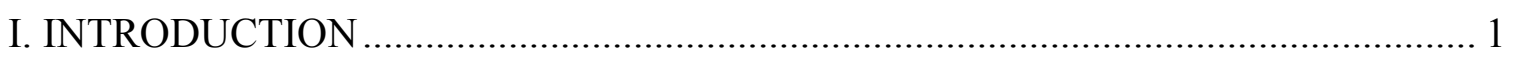

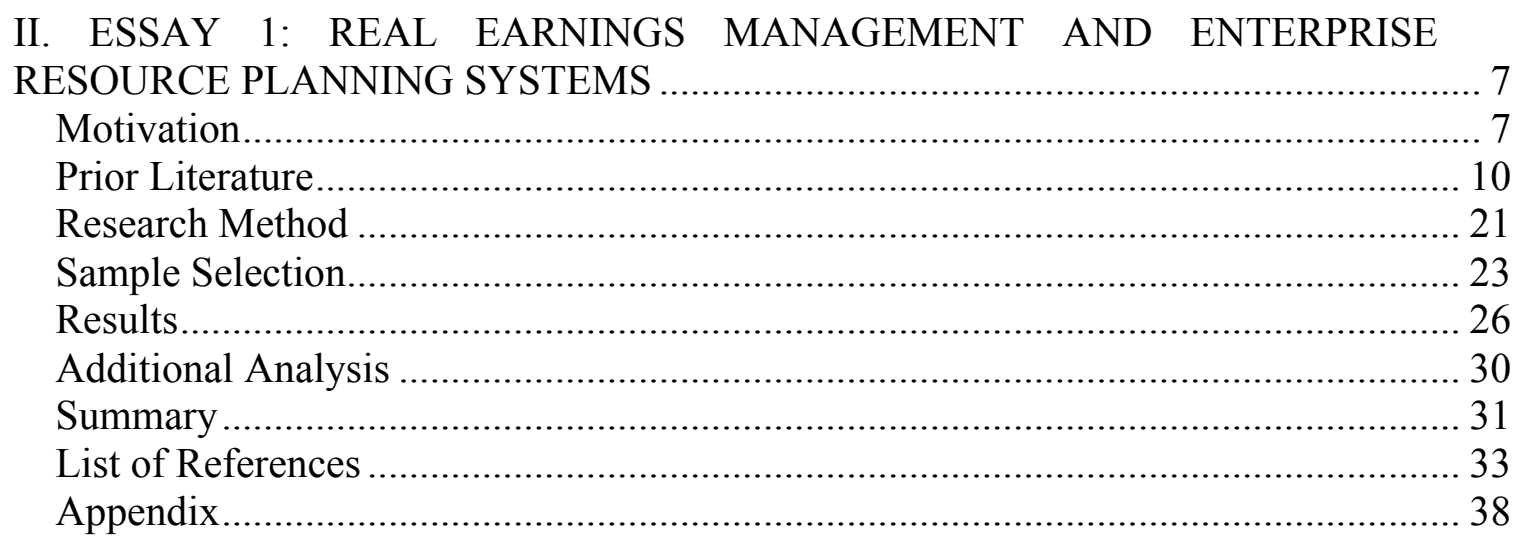

III. ESSAY 2: REAL EARNINGS MANAGEMENT AND AUDIT REPORT LAG..... 61

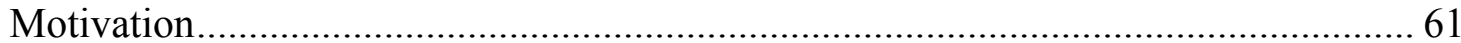

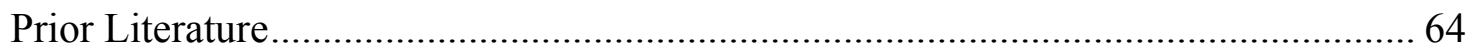

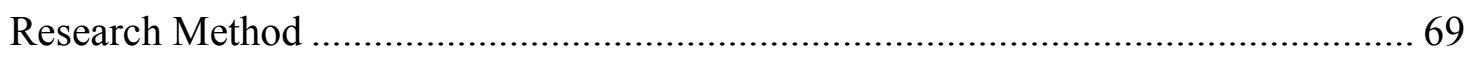

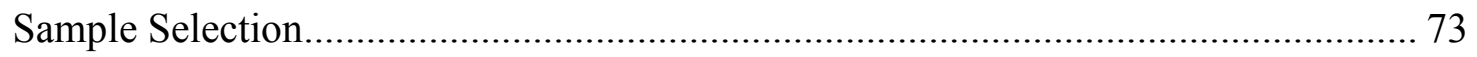

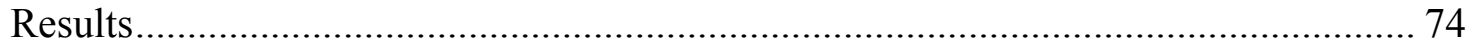

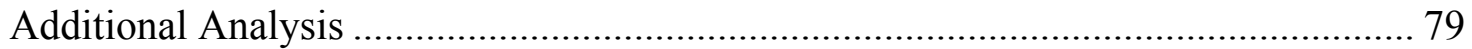

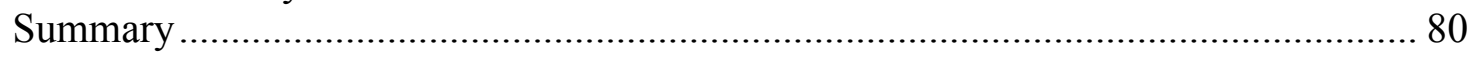

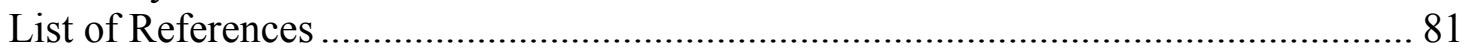

IV. ESSAY 3: REAL EARNINGS MANAGEMENT AND FUTURE

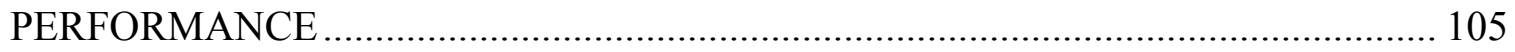

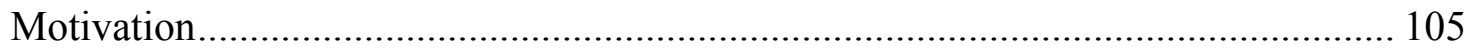

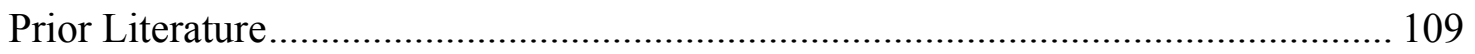

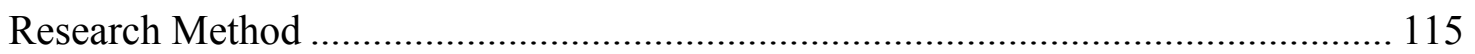

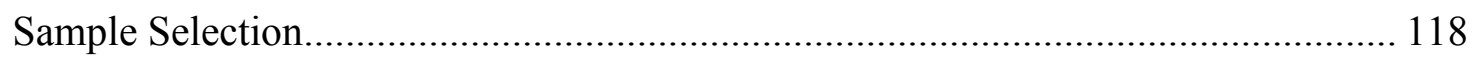

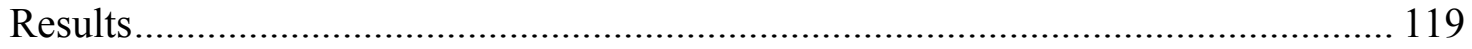

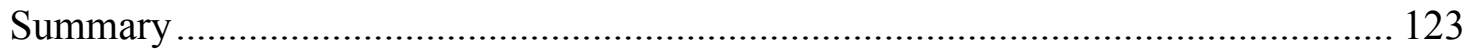

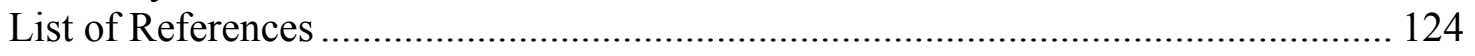

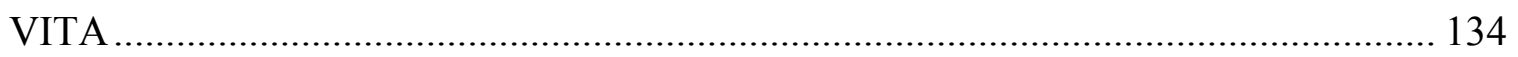




\section{LIST OF TABLES}

TABLES

PAGE

ESSAY 1: REAL EARNINGS MANAGEMENT AND ENTERPRISE RESOURCE PLANNING SYSTEMS

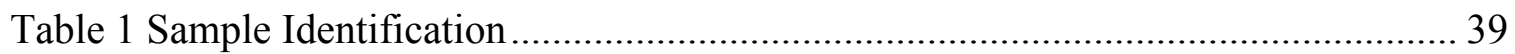

Table 2 Descriptive Statistics for Earnings Management Measures and Control

Variables

Table 3 Pearson Correlations for Model Variables........................................................ 47

Table 4 Univariate Tests of Equality of Means - Earnings Management Measures ........ 49

Table 5 Regression Analysis of Earnings Management: Pre versus Post ERP

Implementation 51

Table 6 Regression Analysis of Earnings Management for Suspect Firms: Pre versus

Post ERP Implementation

Table 7 Regression Analysis of Earnings Management: Pre versus Post

Implementation for Implementers and Control Sample

Table 8 Regression Analysis of Earnings Management for Suspect Firms: Pre versus

Post Implementation - Implementers and Control Sample

Table 9 Efficient Model Analysis of Earnings Management: Pre versus Post

Implementation - Implementers and Control Sample

Table 10 Efficient Model Regression Analysis of Earnings Management for Suspect

Firms: Pre versus Post Implementation - Implementers and Control Sample 60

ESSAY 2: REAL EARNINGS MANAGEMENT AND AUDIT REPORT LAG

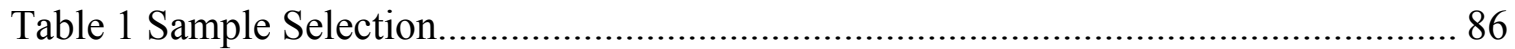

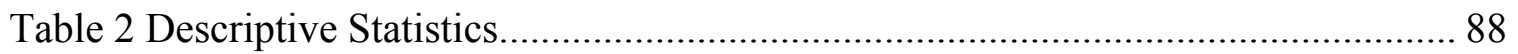

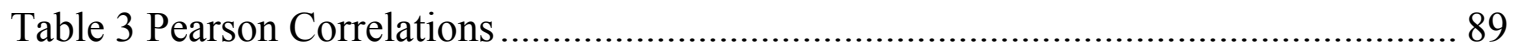

Table 4 Real Earnings Management and Audit Report Lags ..................................... 93

Table 5 Regression Suspects VS Non-Suspects (Subsample) .................................... 95

Table 6 Accelerated vs Non-Accelerated (Subsample) .......................................... 98 
Table 7 REM and Audit Report Lags for Suspect Firms: Accelerated vs NonAccelerated

Table 8 Short and Long Audit Report Lag ............................................................... 103

ESSAY 3: REAL EARNINGS MANAGEMENT AND FUTURE PERFORMANCE

Table 1 Descriptive Statistics................................................................................ 128

Table 2 Regressions of Abnormal Discretionary Expense on Return on Assets............ 129

Table 3 Regressions of Abnormal Discretionary Expense on Annual Stock Returns .... 131

Table 4 Regression of Over-Production on Year-Ahead Sales Growth and Return on Sales 


\section{INTRODUCTION}

This dissertation examines the extent to which real earnings management [REM] is associated with the adoption of enterprise resource planning systems [ERPs], audit report lags, and future performance. According to Healy and Wahlen (1999) earnings management can be classified into two categories: accruals management and real earnings management. The former involves generally accepted accounting principles [GAAP], and occurs when managers manage reported earnings by using the accounting discretion allowed under GAAP. The latter occurs when managers take actions that change the timing or structure of actual business activities. Real earnings management has received considerable attention since Graham, Harvey and Rajgopal (2005) reported that $80 \%$ of the U.S. executives they surveyed, were willing to reduce R\&D, advertising, and maintenance in order to meet earnings benchmarks. Their finding is significant in that it suggests that managers are willing to sacrifice future performance in order to meet current period financial reporting targets. Furthermore, Cohen, Dey and Lys (2008) demonstrate, that after passage of the Sarbanes-Oxley Act [SOX], firms shifted from earnings management through accruals manipulation, to earnings management through REM. After the passage of SOX, earnings management through accruals became more likely to draw scrutiny from auditors and regulators (Cohen et al. 2008), and, as shown by Ewert and Wagenhofer (2005), in a rational expectations equilibrium model, regulations that are intended to improve earnings quality can actually lead to a substitution effect between accruals management and REM.

The importance of studying this phenomenon derives from the generally held belief that REM negatively affects the future performance of firms engaged in these 
practices (Cohen and Zarowin 2010; Roychowdhury 2006; Badertscher 2011). Roychowdhury (2006) conjectures that real activities manipulations can diminish firm value, since these practices have a negative effect on the future cash flows. In addition, Kim and Sohn (2013) show that REM is costly because the capital markets detect the adverse future consequences of REM which in turn leads to an increase in the cost of capital

In order to more fully understand the impact of this phenomenon, I investigate in this dissertation whether REM (similar to accruals management) is constrained by ERP implementation (Morris and Laksmana 2010), whether REM has an impact on audit effort (Caramanis and Lennox 2008; Lee \& Son 2009), and whether REM actually does have a negative impact on future firm performance (Graham, et al. 2005). This dissertation consists of three interrelated essays addressing the topics outlined above. The essays are: 1) Real Earnings Management and Enterprise Resource Planning Systems; 2) Real Earnings Management and Audit Report Lag; and, 3) Real Earnings Management and Future Performance.

Firms implement enterprise resource planning systems to obtain five primary benefits: business process automation; improvement in supply chain efficiency; elimination of redundancies; cost reductions; and timely access to management information (Rizzi and Zamboni 1999; Latamore 2000; Yusuf, Gunasekaran and Abthorpe 2004). An ERP system is modular business software that integrates all aspects of a company's manufacturing, sales and marketing, purchasing and distribution, project management, human resources and other systems so as to enable an enterprise to efficiently and effectively manage its resources. They are designed as an integrated set of 
modules that address a wide range of basic corporate functions (Robey, Ross and Boudreau 2002). Building on this, an extensive literature has examined the beneficial impact of ERPs on firm performance (Poston and Grabski 2001; Hitt, Wu and Zhou 2002; Hunton, Lipincott and Reck 2003; Nicolaou 2004; Chapman and Kihn 2009). Prior studies have also examined how ERP system implementations have impacted the quality of financial information (Brazel and Dang 2008; Morris and Laksmana 2010; Dorantes, Li, Peters and Richardson 2013; Kim, Nicolaou and Vasarhelyi 2013). Few studies have, however, addressed the question of whether the increase in managers' access to accounting data differentially influences managerial behavior and, those that have, employ predominately pre Sarbanes-Oxley Act implementation data and or include ERP sub-elements in the analysis. In my first essay, I investigate the association of ERP implementation (post SOX) with managers' ability to deviate from normal operating practices to present better financial results. In essence, I investigate whether ERP implementations enhance the quality of financial reporting by constraining real earnings management.

Using a sample of 109 firms that disclosed in 10-K SEC filings that they implemented an ERP between 2002 and 2013, I find a significant negative association between REM and ERP implementation. These results hold even in comparison to a control group of firms that had not implemented ERPs. These findings show a decrease post implementation REM both in my tests solely on implementers and in my tests where implementers where compared to the control group. This suggests that the real time reporting capabilities of ERPs (information access) do not facilitate real earnings management. Rather, ERPs appear to moderate earnings management though REM. 
There is, again, extensive literature examining the impact of accruals management on auditor effort and audit quality (Caramanis and Lennox 2008; Blankley, Hurtt and MacGregor 2014; Lobo and Zhao 2013; Schelleman and Knechel 2010). Prior research shows that higher quality auditors constrain earnings management via accruals manipulation. Thus an unintended consequence of higher quality auditors is that firms with incentives to manage earnings engage in higher levels of REM (Chi, Lisic and Pevzner 2011). Furthermore, as noted by Ewert and Wagenhofer (2005) REM increases with regulatory scrutiny and/or auditor monitoring. The substitution effect from accruals management to REM may affect auditors' client-relations decisions, since auditors are concerned about clients that engage in abnormal operating practices. For example, Kim and Park (2014) show that REM is associated with a higher likelihood of auditor resignation.

PCAOB AU Section 329A Substantive Analytical Procedures calls on auditors to consider unexplained differences that may indicate an increased risk of material misstatement. O'Keefe, Simunic and Stein (1994) find that increases in risk exacerbates the scope of the audit plan, resulting in more audit hours being assigned. Thus the presence of abnormal differences that result from REM may increase audit risk and require more audit work to be performed

Similar to the ERP literature noted above, there exists little in the way of examinations of the association of audit quality and auditor effort with REM. Commerford, Hermanson, Houston and Peters (2014) note, however, that anecdotal evidence indicates detection of REM leads auditors to look more closely at a firms accruals. In my second essay I empirically test this conjecture by examining whether 
auditors identify REM that is coincident with firms meeting or beating earnings benchmarks such that REM is associated with greater audit effort as measured through audit report lags.

Using U.S. firm data from 2004 to 2014, I find a positive association between REM and audit report lags. I performed my analysis using Roychowdhury's (2006) measures of REM (abnormal operating cash flows, abnormal discretionary expenses and abnormal production) and the time between the fiscal year end and the date of the audit report. In addition, I focus on firm-years where firms' just meet/beat zero earnings and or the previous year's earnings, and on accelerated versus non-accelerated filers. My results suggest that after controlling for other factors, auditors perceived firms that engage in real earnings management activities as being more risky - a situation that requires additional audit effort.

Prior studies generally posit that REM is likely to reduce shareholder wealth, since it impacts business operations and long-term firm value. The general speculation regarding REM is that it has a negative impact on future performance (e.g., Roychowdhury 2006; Cohen and Zarowin 2010; Zang 2012, Kim and Sohn 2013; and Kim and Park 2014). Gunny (2010) finds, however, that firms that just meet earnings benchmarks by engaging in R\&D or SG\&A REM have significantly higher subsequent industry-adjusted ROA than firms that do not. She suggests that REM may thus be a mechanism firms use to signal future performance to the capital markets. Given this result Zhao, Chen, Zhang and Davis (2012) find that when firms fail to meet benchmark targets, REM is negatively associated with future performance, while REM coincident with meeting benchmarks is positively associated with future performance. Based on 
these results, I hypothesize that REM is not always "earnings management" in a negative sense. What may be thought of as REM, could be "just business." In my third essay I investigate the circumstances (restructurings and expected future sales increases) that may differentiate between these, and their impact on future operating performance.

Using Roychowdhury's (2006) models and a sample of firms for the years 1998 through 2014, I find that when I control for restructurings, reductions in discretionary expenses that would ordinarly be indicative of REM are instead associated with improved future ROA and secutity returns. I further find that when I control for future sales growth, overproduction is also associated with improved ROS as it is with future increases in cost of goods sold. Together, these results may explain the contradictory results presented in prior research with respect to the imapct of REM on future performance - that is, some of what has been identified as REM in prior studies may, in fact, be "just business."

The remainder of this dissertation is organized as follows: Chapter II discusses REM and ERPs. Chapter III presents an analysis of REM and audit report lags, and Chapter IV identifies circumstances where what would otherwise be identified as REM is positively associated with future firm performance. 


\section{ESSAY 1: REAL EARNINGS MANAGEMENT AND ENTERPRISE RESOURCE PLANNING SYSTEMS}

\section{Motivation}

An extensive literature has examined the beneficial impact of enterprise resource planning systems [ERP] on firm performance. Prior studies have also examined how ERP system implementations have impacted the timeliness of financial information. Few studies have, however, addressed the question of whether the increase in managers' access to accounting data differentially influences managerial behavior. I investigate the association of ERP implementation with managers' ability to deviate from normal operating practices to present better financial results. My findings suggest that after the implementation of an ERP, earnings management through real activities declines. These results uniquely indicate that ERP implementations enhance the quality of financial reporting by constraining opportunistic managerial behavior.

The objective of this paper is to examine the impact of information technology on earnings management through accruals and through real activities [REM]. Specifically I examine the association of enterprise resource planning systems, and earnings management subsequent to the implementation of those systems. SFAC 2 (FASB 1980, 2) tells us that "timeliness, that is, having information available to decision makers before it loses its capacity to influence decisions, is an ancillary aspect of relevance" and that if information is "made available more quickly without making it materially unreliable... its overall usefulness may be enhanced" (para 57). While access to timely information would generally be considered a good thing, an enhanced decision-making environment may also encourage or even facilitate earnings management. On the other hand the 
enhanced monitoring that is possible with ERPs may impede opportunistic behavior by managers. Since earnings management has received so much attention from legislators, regulators and practitioners in recent years, I believe the impact of ERPs on managerial opportunism is a subject worthy of examination.

Firms implement enterprise resource planning systems [ERPs] to obtain five primary benefits: business process automation; improvement in supply chain efficiency; elimination of redundancies; cost reductions; and timely access to management information (Rizzi and Zamboni 1999; Latamore 2000; Yusuf, Gunasekaran and Abthorpe 2004; Kim, Nicolaou and Vasarhelyi 2013). Building on this, an extensive literature has examined the beneficial impact of ERPs on firm performance (Poston and Grabski 2001; Hitt, Wu and Zhou 2002; Hunton, Lippincott and Reck 2003; Nicolaou 2004; Chapman an Kihn 2009). Prior studies have also examined how ERP system implementations have impacted the quality of financial information (Brazel and Dang 2008; Morris and Laksmana 2010; Dorantes, Li, Peters and Richardson 2013). I extend this stream of research by, addressing the question of whether more timely access to accounting data differentially influences managerial behavior.

Following the suggestion of Masli, Richardson, Sanchez and Smith (2011), that researchers "examine the link between IT investment and accounting and related financial processes" (p. 109) as well as the link between IT investment and business strategy, and assuming that the information managers are able to glean from an ERP system is, in fact more timely, I examine the association of access to timely information with earnings management through real activities as well as accruals. I chose to examine the association of ERP implementation with a broad spectrum of earnings management 
for four reasons. First, prior research regarding ERPs and earnings management has focused solely on accruals manipulation. Although this form of earnings management may be less costly to firms, ${ }^{1}$ it is also true that it may have been largely abandoned in favor of costly real activities management in the post Sarbanes-Oxley Act environment (Cohen, Dey, and Lys 2008). Second, the conflicting results of prior research means the question of whether an enhanced information environment is conducive to more or less earnings management is still unanswered (Brazel and Dang 2008; Morris and Laksmana 2010; Dorantes, et al. 2013). Third, the prior research noted above, has primarily sampled ERP implementations at large firms that are more likely to have had sophisticated internal control systems prior to their ERP implementations. My sample is representative of the medium sized firms that comprise the majority of recent ERP implementations, many of which implemented ERPs, in large part, to enhance their internal control systems (Dorien and Wolf 2000; Forger 2000; Kumar, Pollanen and Maheshwari 2008). Finally, the majority of prior studies examine ERP implementations over a time period that is predominately pre SOX, and that includes shocks such as the dot-com 'bubble' and the Y2K phenomenon (Brazel and Dang 2008; Dorantes, et al. 2013). As a consequence, the results of those studies may not be generalizable to today.

My tests include both within-firm tests for differences pre and post ERP implementation, and tests against a matched control sample. In order to confirm that any change in earnings management is mainly caused by the ERP implementation I apply a difference in difference test. I do not find a significant association between ERPs and

${ }^{1}$ Kim and Sohn (2013) find that the financial markets require a higher risk premium when firms engage in REM and that this premium is incremental to that required by firms engaging in earnings management through accruals. 
abnormal accruals in either the pre or post implementation periods. This result is consistent with Dorantes et al., (2013) in that I find no evidence of a change in accruals management after ERP implementation. When I extended the analysis to include earnings management that occurs through real activities, however, my results reveal that these activities decrease post implementation. This suggests that while real time reporting capabilities could encourage or facilitate the use of real earnings management [REM], this is not the case. These results are robust to tests on a sub-sample of suspect firms who beat prior period earnings by a small margin. This result holds despite the fact that I find no difference in the likelihood that firms meet or beat analyst expectations pre versus post implementation. My research contributes to the ongoing literature on the relationship between accounting information systems and external financial reporting, as well as to the literature examining earnings management per se.

The remainder of this paper is organized as follows. The next section discusses the background and related research and develops the hypotheses. The third section presents my research design. The fourth section discusses my sample selection and the fifth reports my results. The sixth section offers conclusions and implications.

\section{Prior Literature}

\section{ERP Systems}

An ERP system is modular business software that integrates all aspects of a company's manufacturing, sales and marketing, purchasing and distribution, project management, human resources and other systems so as to enable an enterprise to efficiently and effectively manage its resources. They are designed as an integrated set of modules that address a wide range of basic corporate functions (Robey, Ross and 
Boudreau 2002). Furthermore, they are valued by managers because they are integrated, and provide direct access to real time information. ${ }^{2}$

According to Grabski, Leech and Schmidt (2011), ERP research can be classified into three groups: (1) ERP critical success factors, (2) ERP economic impact and (3) ERP organizational impact. This latter group addresses the impact of ERP systems on management accounting.

\section{ERPs and Accruals Management}

An ERP can limit managerial control choices and the initial configuration can have a long-term impact on restricting a company's control systems (Grabski et. al 2011). Given these restrictions, managers' ability to deviate from normal accounting practices should be reduced after an ERP is implemented. ERP systems may, for example, reduce accruals management, because the information provided may encourage managers to act in the best interest of the investors (Morris and Laksmana 2010). Furthermore, companies that adopt an ERP system are reported to have fewer internal control weaknesses (Masli, et al. 2010; Morris 2011) and, as described below, some companies implemented ERPs specifically to conform to the internal control standards required by Sarbanes-Oxley Section 404. Prior research (Dorantes, et al. 2013) also suggests that ERP systems improve the quality of internal information by facilitating managers' access to timely and accurate data.

Three papers have examined the effect of ERPs on accruals management with limited and mixed results. Brazel and Dang (2008) study the impact of enterprise systems

${ }^{2}$ Elliott noted in 2002 that "enterprise-wide software in networked organizations already permits some firms to report - at least internally - in near real time" (page 140). 
on measures of information quality and find that discretionary accruals increase significantly following an ERP implementation. In contrast, Morris and Laksmana (2010) find a significant drop in the absolute value of discretionary accruals and total accruals after firms implement ERPs. Finally, Dorantes, et al. (2013) find no significant association between enterprise system implementation and abnormal accruals in the preand post implementation periods.

The mixed results presented in prior research may, however, be a reflection of the different sample periods employed and the definitions of what constitutes an ERP. The sample period of Morris and Laksmana (2011) covers implementations in the years 1994 through 2003 while the sample period of Brazel and Dang (2008) goes from 1993 through 1999. Both of these time periods include the dot-com bubble, and the Y2K crisis, and Morris and Laksmana include the beginning of the post SOX period as well. While I make no predictions and conduct no tests pre versus post-SOX, it is likely that implementations post SOX were fundamentally different from early ERP implementations. As a consequence, I focus my analysis on the post-SOX period. According to Kumar, et al. (2008) SOX provided incentives to companies to implement an ERP system, because ERPs can help firms to develop and manage effective controls. While the sample of Dorantes, et al. (2013) extends further into the post SOX period (1995-2008), fifty-eight percent of their sample implementations occurred pre SOX (page 1434). Their results may also be a function of their inclusion of various systems that are pieces of, but not the equivalent of ERPs. For example, supply chain management 
systems, business intelligence systems, customer relationship management systems, Ebusiness platforms, and enterprise integration applications are included in their sample. ${ }^{3}$

\section{Sarbanes-Oxley}

The specific reasons companies invest in this technology vary, but ERP implementations are typically attributed to cost reduction and productivity enhancements. After the Sarbanes-Oxley Act [SOX] was passed by the U.S. congress and signed into law in 2002, the dynamics of financial reporting changed. The new requirements forced many companies to consider implementing ERPs in order to attain compliance with SOX. This is because ERP systems can provide technical tools and solutions not only for collecting, analyzing and reporting information but also for implementing internal controls.

There are three main sections of SOX that affect IT governance: Section 302, Section 404 and Section 802. Section 302 requires a set of internal procedures designed to ensure accurate financial disclosures and assurance from fraud. Section 404 focuses on the assessment of internal controls. This section requires executives and auditors to report on the adequacy of the company's internal control over financial reporting. Executives are also required to generate an internal control assessment that acknowledges the responsibility of management for maintaining an adequate internal control structure. Furthermore, the report contains an assessment of the effectiveness of the internal control structure (including IT controls) and procedures. Executives generally have adopted an internal control framework like the Committee of Sponsoring Organization (COSO) of

${ }^{3}$ ERPs make up the bulk (55\%) of their sample (page 1435) but the year of implementation corresponding to the various types of "enterprise systems" that they include is not disclosed. 
the Treadway Commission for this assessment. Section 802 of SOX mandates appropriate record retention and security for five years and imposes criminal penalties for violation of the act.

While the ERP tools prior to SOX provided some benefit, their effectiveness was lacking in comparison with more robust solutions introduced in the later stages of SOX. As the requirements for compliance became, however, more familiar to companies and ERP vendors, vendors reexamined their software and offered solutions that include a greater emphasis on compliance and control (Krell 2007). As such, a new generation of ERP systems was launched after 2002 that provide technical tools and solutions for gathering, analyzing and reporting information necessary for implementing the internal controls required by SOX. In response to this, a number of companies implemented ERPs in order to achieve SOX compliance. Hawkins Inc., for example, reported in its 10-K filing on Mar-28-2004 that:

"The Company is currently implementing an Enterprise Resource Planning (ERP) system. The ERP system implementation is critical for the Company to make its internal control certifications required by the end of fiscal 2005 pursuant to Section 404 of the Sarbanes-Oxley Act. The Company believes the ERP system will be implemented by October 1, 2004." and Bioanalytical Systems Inc. reported in its 10-K filing on Sep-30-2005 that:

"Also in fiscal 2004, the Company initiated implementation of a new Enterprise Resource Planning ("ERP") system, which was launched at all the Company's locations in the third quarter of fiscal $2005 \ldots$ The introduction of a new ERP system is part of the Company's response to the Sarbanes-Oxley Act 
(the "Act"). The Company determined that it was not practicable to comply with the control, documentation and testing requirements of Section 404 of the Act while operating on different, decentralized, obsolete systems at its various locations."

Prior research has also shown, however, that ERP system adoptions have provided managers with more flexibility to manage earnings due to reductions in internal control effectiveness and audit quality in the ERP system setting (Wright and Wright 2002; Brazel and Agoglia 2007). There are a number of ERP characteristics that impact security and internal control: the degree of standardization, authorization and centralization. The control executed by managers over financial information through a centralized ERP system may thus facilitate increased managerial discretion, since this control technology is sometimes fragile when companies pursue more integration (Dechow and Mouritsen 2005). In this circumstance, a centralized system can provide the opportunity for inappropriate access privileges that may violate internal control requirements (Grabski et. al 2011). The ability of an ERP to process thousands of transactions daily poses additional problems for control, in that the shear volume of transactions makes it difficult to identify anomalies (Singh, Best, Bojilov and Blunt 2014), and in the absence of a continuous auditing / continuous monitoring system, it may be impossible to effectively control opportunistic managerial behavior. Thus I might expect accruals manipulation to increase after an ERP implementation.

These competing conjectures lead to my first hypotheses (in null form):

H1: Implementation of an ERP system will not be associated with earnings management through discretionary accruals. 


\section{Real Earnings Management}

According to Healy and Wahlen (1999) earnings management can be classified into two categories: accruals management and real earnings management. The former involves generally accepted accounting principles [GAAP], and occurs when managers manage reported earnings by using the accounting discretion allowed under GAAP. The latter occurs when managers take actions that change the timing or structure of actual business activities. Real earnings management has received considerable attention since Graham, Harvey and Rajgopal (2005) reported that $80 \%$ of U.S. executives surveyed, were willing to decrease expenditures on $R \& D$, advertising, and maintenance in order to meet earnings benchmarks. ${ }^{4}$

ERP systems provide companies with reliable, transparent, real-time data access, which gives managers the opportunity to make better and faster business decisions. It is also expected that, after implementation, there will be an improvement in data access that will lead to more accurate forecasting, and that the integration of various functional areas will lead to improved communication, productivity and efficiency. Given the benefits ERPs yield in the reporting process, this technology may improve managements' ability to engage in real earnings management. This is because REM requires assessment and planning and ERPs dramatically improve both of those processes.

Roychowdhury (2006, 337) defines real earnings management as "departures from normal operational practices motivated by managers' desire to mislead at least some

\footnotetext{
${ }^{4}$ Managers may also use REM do reduce earnings when there are incentives to do so (Eldenburg, Gunny, Hee and Soderstrom 2011; Chen and Huang 2013). Eldenburg et al., show, for example, that when the earnings of non-profit hospitals exceed benchmarks, managers increase non-operating expenditures to effect a reduction in earnings.
} 
stakeholders into believing certain financial reporting goals have been met in the normal course of operations." The motivations for managers to engage in REM are the same as those that motivate accruals management, and include concealing undesirable performance, limiting earnings variability, and maximizing bonus compensation (Healy and Wahlen 1999). Real earnings management can, however, be costly to firms and shareholders, and the overwhelming majority of studies have focused on the negative economic consequences of REM (Roychowdhury 2006; Cohen and Zarowin 2010; Zang 2012; Kim and Sohn 2013; Kim and Park, 2014). The evidence from those prior studies indicates that REM increases a firm's cost of capital and imposes greater long term-costs on shareholders because of its negative impact on future cash flows. Badertscher (2011), for example, finds that firms first engage in accruals management and later move to REM, while Cohen and Zarowin (2010) find that declining operating performance after seasoned equity offerings is more severe when managers engage in REM than when they engage in accruals management. Similarly, Bhojraj, Hribar, Picconi and McInnis (2009) find that short-term stock market gains achieved by cutting discretionary expenses to meet earnings targets are reversed in future periods.

Declining firm performance and financial health may also increase auditor risk and increased auditor risk impacts client retention. Kim and Park (2014) found, for example, that auditors are more likely to resign when clients engage in aggressive REM practices. As noted above, research on REM has revealed negative consequences resulting from this practice, Gunny (2010) finds, however, that firms engaged in REM have better operating performance in the following years. 
Cohen et al., (2008) examined changes in earnings management practices over time. Their evidence suggests that firms shifted from using accrual-based to real earnings management after SOX, because real activities methods are harder to detect and accrual manipulations are more likely to draw auditors' or regulators' scrutiny. According to Zang (2012), real earnings management increased due to the higher level of scrutiny of accounting practices after the passage of SOX. This is because regulatory bodies like the U.S. Securities and Exchange Commission [SEC] are focusing more attention on "an apparent increase in abusive earnings management" and, as a consequence, auditors pay more attention to accruals management than to real earnings management. Chi, Lisic and Pevzner (2011) suggest that this occurs because REM does not involve the violation of any regulations.

As described above, earnings management can be achieved by taking advantage of accounting discretion or by changing the timing or structure of real transactions (Bartov 1993; Ewert and Wagenhofer 2005). A unique characteristic of this latter approach is that it results in a reduction in long-term firm value (Ewert and Wagenhofer 2005; Roychowdhury 2006; Zang 2012), while accruals management is not likely to destroy long-term value (Badertscher 2011). Earnings management choices depend, however, on managerial flexibility. After the passage of SOX, earnings management through accruals became more likely to draw scrutiny from auditors and regulators (Cohen et al. 2008). Furthermore, as noted by Ewert and Wagenhofer (2005) a rational expectations equilibrium model, where regulations are intended to improve earnings quality can actually lead to a substitution effect between accruals management and REM.

${ }^{5}$ SEC January 27, 2000. 
The result is that regulatory actions that restrict managers' ability to use accruals management can increase REM and decrease firm value. Zang (2012) finds, for example, that the substitution between these two strategies depends on the cost to the firm.

Managers may, in general, prefer accruals management to REM because accruals management can take place after the fiscal year has ended while real earnings management must be done prior to fiscal year end. Absent an ERP, this may pose a problem for managers, in that they may not know the extent of REM necessary to meet an earnings target. Real-time information, however, provides managers with direct access to performance measures that they can use to gauge their progress towards benchmarks. This coupled with more accurate forecasting (Dorantes et al. 2013) would encourage or at least facilitate managers' ability to engage in earnings management through real activities. Lawson Products Inc., notes in their 2010 annual report that "I expect that the new ERP will provide us... with the opportunity to make better and faster business decisions... and provide a top-down view of the enterprise" (Exhibit 32).

\section{Monitoring}

On the other hand, the integration of intra-company systems in combination with the monitoring function of ERPs, may constrain managerial discretion over real activities such as changes to production levels or unusual changes in discretionary expenditures. Masli, Peters, Richardson and Sanchez (2010) examine how these new internal control monitoring systems impact firms and find that they are associated with a lower likelihood of material weaknesses in the year following implementation, and smaller increases in audit fees and audit lags. Similarly, Cohen, Hoitash, Krishnamoorthy and Wright (2014) find that monitoring (audit committee members with both accounting and industry 
expertise) is associated with higher reporting quality and less earnings management. The ability to monitor CEO actions is key to ERPs limiting earnings management. Acharya, Myers and Rajan $(2011,689)$ develop a model of "internal governance" where "the selfserving actions of top management are limited by the potential reaction of subordinates." Building on their model, Cheng, Lee and Shevlin (2016) show that REM is inversely related to the employment horizon and influence of key subordinates and attribute this to those executives caring more than the CEO about long-term firm performance. Since ERPs would enhance the information set available to key subordinates, REM would likely decrease after an ERP implementation.

Consider, for example, the setting where a manager's bonus compensation is tied to earnings targets. The manager has real time information (from the ERP) and knows what level of performance is yet needed to meet those targets. The manager would like to increase production so as to shift fixed costs and overhead from cost-of-goods-sold to inventory thus boosting income and insuring the receipt of the bonus. Here, one of two scenarios could play out: 1) The manager uses the information from the ERP to overproduce and collects the bonus (the decision to overproduce being hidden in the vast volume of information processed by the ERP); or 2) The threat of this behavior being detected by the board of directors (the top-down view of the enterprise), or by key subordinates prevents the opportunistic behavior. This second scenario exists because ERPs in a manufacturing setting are specifically designed to improve supply chain management and facilitate more efficient production schedules. Thus any unusual over production is likely to raise suspicions. As with my discussion of accruals, I again have competing conjectures. 
My second hypothesis (in null form) is thus:

H2: Implementation of an ERP system will not be associated with earnings management through real activities.

\section{Research Method}

To measure earnings management through accruals, I estimate cross-sectional modified Jones discretionary accruals, adjusted for prior year performance as presented in Kothari, Leone, and Wasley (2005). Specifically, $\mathrm{ROA}_{t-1}$ is added as an additional independent variable to the modified Jones model. To measure real earnings management, I employ the three proxies of Roychowdhury (2006) and Cohen, et al. (2008): abnormal cash flow from operations [REMCASH], abnormal discretionary expenses [REMDISC], and abnormal production costs [REMPROD]. These four measures serve as dependent variables in my multivariate tests. ${ }^{6}$

I then compute two comprehensive measures of abnormal real activities by aggregating the individual measures, to capture the overall level of real activity manipulation (Zhao, Chen, Zhang and Davis 2012; Cohen 2010). I compute the first of these measures [REM1] by summing abnormal production costs and abnormal discretionary expense. For the second measure [REM2] I aggregate all three of the real earnings management measures.

Following prior literature (Kim and Park 2014; Zhao, et al. 2012; Zang 2012), I include additional independent variables to control for factors that are associated with managerial motivations and opportunities to engage in earnings management [EM], the

\footnotetext{
${ }^{6}$ My estimation models are run by two digit SIC code and year on a minimum of 15 observations.
} 
costs of EM, and governance features that might have an effect on discretionary accruals and real earnings management. ${ }^{7}$ My resulting test model for differences within implementers is:

$$
\begin{aligned}
\mathrm{EM}= & \beta_{0}+\beta_{1} \mathrm{ERP}+\beta_{2} \mathrm{LGTA}+\beta_{3} \mathrm{ROA}+\beta_{4} \mathrm{AUD}+\beta_{5} \mathrm{MTB}+\beta_{6} \mathrm{LEV}+ \\
& \beta_{7} \mathrm{NOA}+\beta_{8} \mathrm{MKTSHARE}+\beta_{9} \mathrm{INST}+\beta_{10} \% \mathrm{CL}+\beta_{11} \mathrm{ZSCORE}+ \\
& \beta_{12} \mathrm{MANU}+\beta_{13} \mathrm{AUDTEN}+\beta_{14} \mathrm{CYCLE}+\beta_{15} \mathrm{MTR}+\beta_{16} \mathrm{ACCR}+ \\
& \text { Year }+\varepsilon
\end{aligned}
$$

The test model for my difference in difference (implementer versus control) tests is:

$$
\begin{aligned}
& \mathrm{EM}=\beta_{0}+\beta_{1} \mathrm{ERP}+\beta_{2} \mathrm{POST}+\beta_{3} \mathrm{ERP} \times \mathrm{POST}+\beta_{4} \mathrm{LGTA}+\beta_{5} \mathrm{ROA}+ \\
& \beta_{6} \mathrm{AUD}+\beta_{7} \mathrm{MTB}+\beta_{8} \mathrm{LEV}+\beta_{9} \mathrm{NOA}+\beta_{10} \mathrm{MKTSHARE}+\beta_{11} \mathrm{INST}+ \\
& \beta_{12} \% \mathrm{CL}+\beta_{13} \mathrm{ZSCORE}+\beta_{14} \mathrm{MANU}+\beta_{15} \mathrm{AUDTEN}+\beta_{16} \mathrm{CYCLE}+ \\
& \beta_{17} \mathrm{MTR}+\beta_{18} \mathrm{ACCR}+\text { Year }+\varepsilon
\end{aligned}
$$

The independent variable, [LGTA], is the natural $\log$ of total assets which controls for variations in earnings management associated with firm size. I include return on assets [ROA] to control for firm profitability. Consistent with Cohen et al. (2010) and Chi et al. (2011) I include a Big 4 indicator variable [AUD] and auditor tenure [AUDTEN], since clients of large audit firms and longer auditor tenure are associated with higher levels of REM. Furthermore, I include the market to book ratio [MTB] to control for growth opportunities. Following Zang (2012) I include market share [MKTSHARE], institutional ownership [INST], Altman's Z-score [ZSCORE] and the

\footnotetext{
${ }^{7}$ Variable definitions are presented in Appendix.
} 
marginal tax rate $[\mathrm{MTR}$ ] to control for the costs associated with REM. Firms with a higher Z-score and managers in market leader firms are more likely to take real economic actions to manipulate earnings. Conversely, firms with high marginal tax rates and institutional ownership are less likely to engage in REM.

I include net operating assets $[\mathrm{NOA}]$ and discretionary accruals [ACCR] to control for accounting flexibility, and similar to Chan, Chen, Chen and Yu (2015), I include business cycle [CYCLE] to control for the costs related to accrual manipulation. Prior research has shown that leverage $[\mathrm{LEV}]$ is associated with discretionary accruals. Since earnings management through accruals and REM have been shown to be substitutes and complements (Zang 2012; Chan et al. 2015) I include this variable in my models. Finally, in keeping with Roychowdhury (2006), I include an indicator variable for manufacturing companies [MANU] and a measure of short-term credit risk [\%CL] to control for managerial incentives to engage in earnings management so as to avoid a negative reaction from creditors and suppliers should the firm fail to meet earnings benchmarks. All continuous variables are winsorized at the $1 \%$ and $99 \%$ levels.

\section{Sample Selection}

I collected ERP implementations disclosed between 2002 and 2013. The sample firms were identified by searching the Capital IQ database for ERP implementations that were disclosed in 10-k SEC filings. This approach is based on Nicolaou (2004). I employ it because it reduces any potential selection bias of that may occur when firms implemented an ERP but did not elect to publicly announce the implementation. Such selection bias may be particularly severe when sample firms are identified from proprietary lists not available to the public. The search focused on the time the ERP 
implementation was complete using the following keywords: "enterprise resource planning," "ERP," "implemented," and "went-live." The initial query produced 2,529 documents containing the search terms. Table 1, Panel A presents the sample documents by year. ${ }^{8}$ The remaining documents were analyzed individually to verify that the sample firms had, indeed, completed an ERP implementation and to identify the year of implementation. Subsequently, each of these documents was examined and observations with a legacy ERP, discontinued ERP project, ERP improvement or updated projects and duplicates were deleted. I impose this condition in order to make sure that my sample firms were first time implementers. The majority of the disclosures were presented in the Management's Discussion and Analysis section of the 10-k. The financial data is obtained from the Compustat database. My sample identification process yielded 168 unique ERP implementation firms. In order to compare the pre versus post implementation periods similar to Brazel and Zang (2008), I require the data necessary to construct the earnings management metrics for seven years - three years prior to and three years following the implementation. Because I examine the effect of ERPs on earnings management, I use an indicator variable with a value equal to 1 for the years following ERP implementation, and 0 otherwise. Because I cannot identify exactly when the ERP "went live" the implementation year is not part of my analysis. Sixteen firms were deleted because they lacked the necessary data for post implementation analysis (implemented ERPs after 2011). Two financial institutions were excluded, as were 41

\footnotetext{
${ }^{8}$ The filings of OTC-pink sheet firms were excluded from the sample because the companies are unable or unwilling to meet the minimum U.S. stock market qualifications, and because they are not required to file financial statements with the SEC.
} 
additional firms that lacked complete data items on Compustat for the pre and post implementation periods. Panel B of Table 1 summarizes the sample selection process.

Following Nicolaou (2004) and Morris (2011) I identify a control group to provide a comparison group of firms that had not implemented ERPs. I follow Nicolaou (2004), Morris and Laksmana (2010) and Dorantes, et al. (2013) in matching my sample to 109 unique control firms by SIC code and total assets at the beginning of the implementation year. I employ Mahalanobis Distance to identify the closest match. A new search was then executed, to ensure that the identified control firms had not announced the implementation of an ERP. ${ }^{9}$ Each ERP firm is matched with a control group firm. As a result, the subsequent analyses are of 218 firms (109 ERP implementers and 109 non-implementers).

Table 1, Panel C presents the industry distribution for the sample firms. As in prior research, the majority of the sample firms are from the manufacturing and service industries. The distribution of ERP implementations by year is presented in Table 1, Panel D. Implementations in 2006 and 2010 constitute the largest proportions of the sample (17.4 and 16.5 percent respectively), and 2011 represents the smallest with one implementation ( 0.9 percent).

\footnotetext{
${ }^{9}$ I am unable to determine whether or not some of the control firms implemented legacy ERPs prior to 1999 . However, to the extent that ERP implementers differ systematically in their earnings management practices from non-implementers, the existence of such firms in the control sample would work against me identifying those differences.
} 


\section{Results}

\section{Univariate Results}

Table 2, Presents descriptive statistics for firms that implemented an ERP. Panel A presents the statistics for both the pre and post implementation periods combined, the descriptive statistics for the pre ERP implementation period, and the descriptive statistics for the post implementation period. Panel B presents the same information for the control sample.

Panel $\mathrm{C}$ of Table 2 presents tests of the equality of means for my control variables: implementers versus control group in the pre implementation period. While the incidence of Big 4 auditors [AUD] was low for both groups (means of 0.263 and 0.162 for the implementers and control group respectively), the implementers were significantly more likely to have engaged a Big 4 auditor $(p \leq 0.002)$, have greater market share $((p \leq$ 0.002), and have a longer operating cycle (117.915 days for implementers versus 100.406 for control firms). None of the other control variables are statistically different at conventional levels. This gives me confidence that my matching procedure was successful in identifying a representative control sample.

Table 3 presents Pearson correlations for the model variables. As expected, REMDISC and REMPROD are highly correlated $(r=0.646)$. Also as expected, ZSCORE is negatively correlated with leverage $(r=-0.512)$, operating assets is correlated with total assets $(r=0.528)$, as is institutional ownership $(r=0.506)$. None of the other correlation coefficients are greater than 0.50 .

Table 4, Panel A presents univariate tests of my earnings management measures pre versus post for my implementers. With the exception of REMCASH all of the 
measures reflect less earnings management after the ERP implementation. Of these, however, only ABSDA REMPROD and REM1 are significant at the $p \leq 0.10$ level $(p \leq$ 0.126 and $p \leq 0.101$ for REMDISC and REM2 respectively). The univariate results thus provide some evidence that ERP systems impact earnings management. ${ }^{10}$

Panel B (pre implementation) and Panel C (post implementation) present the same tests for my implementers versus the control group. There is no statistical difference between implementers and the control group for any of the measures in the pre implementation period (the probabilities that ABSDA, REMDISC, REMPROD and REMCASH are equal for implementers and the control group are $0.88,0.90,0.83$, and 0.96 respectively). In the post period, however, the probabilities that the mean values for ABSDA, REMDISC, REMPROD and REMCASH are equal for implementers and the control group are only $0.12,0.10,0.05$, and 0.72 respectively.

\section{Multivariate Results}

Table 5 presents the regression results for my six models. The coefficient on ERP is significantly negative $(p \leq 0.05)$ in the accruals model. This result suggests that earnings management through discretionary accruals declines after ERP implementation. This finding is consistent with the speculation that ERP systems can reduce managers' discretion over accounting information, and that the use of the ERPs encourages managers to act in the best interests of investors.

The real earnings management models also reveal interesting results. The coefficients on ERP in the REMDISC and REMPROD models are similarly negative and

${ }^{10}$ Consistent with prior research, REMDIS and REMCASH are multiplied by negative 1 so that the coefficients can be interpreted in the same manner as those on REMPROD and ABSDA. 
significant $(p \leq 0.01)$, but the coefficient on REMCASH is not significantly different from zero. These results suggest that ERP systems, even though they provide managers with more timely information, do not facilitate the planning and execution of real activities management through reductions in discretionary expenses or overproduction.

The results from REM1 and REM 2 likewise confirm that ERP adopters engage in less real earnings management, as the coefficients on ERP are also significantly negative for both measures $(p \leq 0.01)$.

\section{Suspect Firms}

Because my initial tests include all of the ERP implementers that I am able to identify, I cannot effectively claim that the reductions in discretionary accruals, expenses and overproduction that I observe, are necessarily reductions in REM. They may instead, be an artifact of ERP adoption unrelated to earnings management. To address this possibility, I follow Gunny (2010) and others in identifying firms that may have greater incentives to manage earnings as those with earnings scaled by total assets that are greater than or equal to the prior year's earnings but less than 0.01 . This screen yields 137 usable observations for my tests (70 pre implementation and 67 post implementation).

Table 6 presents the results of my tests on my sample of suspect firms. In these tests, ERP implementation is significant at conventional levels for the REMDISC and REMPROD regressions, and in the combined models ( $p$-values $\leq 0.05$ ). The coefficients on my other proxies for earnings management are not significant at conventional levels in two-tailed tests. 


\section{Matched Results}

Table 7 presents my regression results when my control sample is included with the ERP implementers - my difference in difference tests. My variable of interest [ERP x POST] is the interaction of ERP with an indicator variable for the post implementation period [POST]. Again the implementation is not significant in the accruals or cash flows models, but is for REMDISC $(p \leq 0.05)$ and REM1 $(p \leq 0.05)$. More importantly, in tests of the overall effect of ERP implementation on REM, the joint coefficients of ERP and ERP $x$ POST $\left(\beta_{1}+\beta_{3}=0\right)$ are significantly associated with reductions in REM for the REMDISC $(p \leq 0.10)$, REMPROD $(p \leq 0.01)$ REM1 $(p \leq 0.01)$ models.

These results indicate that the implementation of an ERP can mitigate the use of REM and deter managers' opportunistic behavior. The tighter accounting system, driven by the implementation of the ERP, can produce better information about the firm and reduce managerial flexibility. This result is consistent with Ewert and Wagenhofer (2005) and with the conjecture of Zang (2012), that firms constrained by heightened regulatory scrutiny will use REM more and accruals less to manage earnings.

Table 8 presents difference in difference tests when I include only suspect firms, both from among the ERP implementers and from the control sample. The control sample contained 141 suspect observations. In the REMDISC model, the coefficient on my variable of interest is again negative and significant $(p \leq 0.10)$ as it is in the REMPROD, REM1 (both $p \leq 0.05)$ and REM2 $(p \leq 0.10)$ models. In joint tests of the overall significance of ERPs on REM, ERP implementation appears, however, not to have constrained our suspect firms. 


\section{Additional Analysis}

Since a large number of the control variables suggested by prior research are not significant in my regressions, my models may suffer from over-specification, i.e., the estimates of the coefficients may be less precise. This is especially the case if some of the extraneous variables are correlated with each other (Baum 2006). LEV and ZSCORE, for example, are likely measuring the same construct. To address this potential problem, I rerun my difference in difference tests using backwards stepwise regression to identify a more efficient model. ${ }^{11}$ The consensus model I arrive at is:

$$
\begin{array}{r}
\mathrm{EM}=\beta_{0}+\beta_{1} \mathrm{ERP}+\beta_{2} \mathrm{POST}+\beta_{3} \mathrm{ERP} \times \mathrm{POST}+\beta_{4} \mathrm{LGTA}+\beta_{5} \mathrm{MTB}+ \\
\beta_{6} \mathrm{NOA}+\beta_{7} \mathrm{INST}+\beta_{8} \% \mathrm{CL}+\beta_{9} \mathrm{MANU}+\beta_{10} \mathrm{CYCLE}+\mathrm{Year}+\varepsilon
\end{array}
$$

The results for my test on the entire sample (implementers and control) are presented in Table 9. Again, the coefficients on the interaction of ERP and POST are negative and significant $(p \leq 0.10)$ for REMDISC and REM1, with the joint tests significant in the REMDISC ( $p \leq 0.10)$, REMPROD $(p \leq 0.05)$ and REM1 models $(p \leq$ 0.05). The results for my suspect firms are presented in Table 10. The coefficients on ERP $x$ POST are negative in the REMDISC, REMPROD and REM1 models ( $p$-values $\leq$ 0.10). In the joint tests implementation is significantly associated with less earnings management for the ABSDA and REMCASH models (both $(p \leq 0.05)$, but not for the others.

Given the results of Dorantes, et al. (2013), I also test whether there is a change in the propensity to meet or beat analyst earnings forecasts post implementation. I calculate the difference between actual earnings and median analysts' forecasts using the last

\footnotetext{
${ }^{11}$ I set the significance level at $p \leq 0.20$ for a variable to be included in the model.
} 
forecast summary reported by IBES prior to the earnings release. I construct two measures for meet/beat. The first is an indicator variable equal to 1 if actual earnings are greater than or equal to the median analyst forecast and 0 otherwise [MEETBEAT]. The second is an indicator variable equal to 1 if actual earnings are greater than or equal to the median analyst forecast, and less than or equal to one-percent of total assets [SMALLBEAT]. This additional measure is to test the conjecture that firms that just barely meet or beat analyst forecasts are more likely to be engaged in earnings management. The firms implementing ERPs exceeded the median analyst earnings forecast 143 times pre implementation and 150 times post implementation $(\alpha=0.861)$. The incidence of SMALLBEAT was 94 in the pre implementation period and 99 in the post implementation period $(\alpha=0.668)$. Thus I find no statistical evidence that the propensity to meet or beat analyst forecasts is lower after an ERP implementation.

I also test whether my results are sensitive to the sample window criteria (three years prior to and three years subsequent to the implementation). I modify the window to include all firm year observations for implementers and the control sample. Because this modified criteria includes companies with different numbers of firm year observations, it leads to unbalanced regressions pre and post ERP implementation. The results of these tests are qualitatively identical to those reported above.

\section{Summary}

I test a sample of ERP implementers post SOX for differences in earnings management practices pre and post implementation. My results show that while firms that implemented an ERP exhibit a reduction in absolute abnormal accruals, this reduction is no greater that that of a matched control group. This suggests that advanced 
information technology is not a driving factor when it comes to managerial discretion with respect to accruals.

When I focus my analysis on earnings management through real activities, I find a decrease post implementation both in my tests solely on implementers and in my implementers when compared to my control group. This suggests that the real time reporting capabilities of ERPs do not facilitate real earnings management. Rather, ERPs appear to moderate earnings management though REM, specifically with respect to discretionary expenses. This result is significant in that while REM violates no rules or regulations, it is generally viewed as having a negative impact on future firm performance. I believe that the enhanced potential for monitoring via the ERP, is the constraining factor that drives my results.

I find substantially the same results when I confine my tests to suspect firms that met or just beat a benchmark of the prior year's earnings. Further, I find no difference pre versus post implementation, in the likelihood that firms meet or beat analyst expectations. Future research should investigate whether alternative mechanisms, such as classification shifting, may have supplanted accruals and real activities management for ERP implementers.

My research contributes to the ongoing literature on the relationship between accounting information systems and external financial reporting, as well as to the literature examining real earnings management as a response to increased regulatory scrutiny of accruals. To the extent that my results are generalizable across firms regulators, auditors and investors may see ERP implementations not just as indicative of enhanced operating efficiency, but of higher quality financial reporting as well. 


\section{List of References}

Acharya, V., S. Myers, and R. Rajan. 2011. The internal governance of firms. The Journal of Finance 66 (3): 689-720.

Badertscher, B. 2011. Overvaluation and the Choice of Alternative Earnings Management Mechanism. The Accounting Review 86 (5): 1491-1518.

Bartov, E. 1993. The Timing of Assets Sales and Earnings Manipulation. The Accounting Review 68 (4): 840-855.

Baum, C. 2006. An Introduciton to Modern Econometrics Using STATA. College Station, TX, STATA Press.

Bhojraj, S., P. Hribar, M. Picconi, and J. McInnis. 2009. Making sense of cents: An examination of firms that marginally miss or beat analyst forecasts. The Journal of Finance 64 (5): 2361-2388.

Brazel, J. and C. Agoglia. 2007. An examination of auditor planning judgments in a complex accounting information system environment. Contemporary Accounting Research 24 (4): 1059-1083.

and L. Dang. 2008. The effect of ERP system implementations on the management of earnings and earnings release dates. Journal of Information Systems 22 (2) 1-21.

Chan, L., K. Chen, T. Chen, and Y. Yu. 2015. Substitution between real and accrualsbased earnings management after voluntary adoption of compensation clawback provision. The Accounting Review 90 (1): 147-174.

Chapman, C. and L. Kihn. 2009. Information system integration, enabling control and performance. Accounting Organizations and Society 34 (2): 151-169.

Chen, S-S. and C-W. Huang. 2013. The Sarbanes-Oxley Act, earnings management, and post-buyback performance of open-market repurchasing firms. Journal of Financial and Quantitative Analysis 48 (6): 1847-1876.

Cheng, Q., J. Lee, and T. Shevlin. 2016. Internal governance and real earnings management. The Accounting Review (forthcoming).

Chi, W., L. Lisic, and M. Pevzner. 2011. Is enhanced audit quality associated with greater real earnings management? Accounting Horizons 25 (2): 315-335. 
Cohen, D., A. Dey, and T. Lys. 2008. Real and accrual-based earnings management in the pre- and post-Sarbanes-Oxley periods. The Accounting Review 83 (3): 757787.

. and P. Zarowin. 2010. Accrual based and real earnings management activities around seasoned equity offerings. Journal of Accounting and Economics 50: 2-19.

Cohen, J., U. Hoitash, G. Krishnamoorthy, and A. Wright. 2014. The effect of audit committee expertise on monitoring the financial reporting process. The Accounting Review 89 (1): 243-273.

Dorantes, C., Ch. Li, G. Peters, and V. Richardson. 2013. The effect of enterprise systems implementation on the firm information environment. Contemporary Accounting Research 30 (4): 1427-146.

Dorien, J. and M. Wolf. 2000. A second wind for ERP. The McKinsey Quarterly, Spring: $100-106$.

Dechow, N. and J. Mouritsen. 2005. Enterprise resource planning systems, management control and the quest of integration. Accounting, Organizations and Society 30: 691-733.

Eldenburg, L., K. Gunny, K. Hee, and N. Soderstrom. 2011. Earnings management using real activities: Evidence from nonprofit hospitals. The Accounting Review 86 (5): 1605-1630.

Elliott, R. 2002. Twenty-first century assurance. Auditing: A Journal of Practice \& Theory 21 (1): 139-146.

Ewert, R. and A. Wagenhofer. 2005. Economic Effect of Tightening Accounting Standards to Restrict Earnings Management. The Accounting Review 80 (4): 1101-1124.

Financial Accounting Standards Board [FASB]. 1980. Statement of Financial Accounting Concepts No. 2, Qualitative Characteristics of Accounting Information. Financial Accounting Standards Board.

Forger, G. 2000. ERP goes mid-market. Modern Materials Handling 55 (1): 65.

Grabski, S., S. Leech, and P. Schmidt. 2011. A review of ERP research: a future agenda for accounting information systems. Journal of Information Systems 25 (1): 3778 .

Graham, J., C. Harvey, and S. Rajgopal. 2005. The economic implications of corporate financial reporting. Journal of Accounting and Economics 40: 3-73. 
Gunny, K. 2010. The relation between earnings management using real activities manipulation and future performance: Evidence from meeting earnings benchmarks. Contemporary Accounting Research 27 (3): 855-888.

Healy, P., and J. Wahlen. 1999. A review of the earnings mamangement literature and its implication for standar setting. Accounting Horizons 13: 365-383.

Hitt, L. D. Wu, and X. Zhou. 2002. Investment in enterprise resource planning: Business impact and productivity measures. Journal of Management Information Systems 19 (1): 71-98.

Hunton, J., B. Lippincott, and J. Reck. 2003. Enterprise resource planning systems: Comparing firm performance of adopters and nonadopters. International Journal of Accounting Information Systems 4 (3): 165-184.

Kim, J., A. Nicolaou, and M. Vasarhelyi. 2013. The impact of enterprise resource planning (ERP) systems on the audit report lag. Journal of Emerging Technologies in Accounting 10: 63-88. . and B. Sohn. 2013. Real earnings management and cost of capital. Journal of Accounting Public Policy 32 (6): 518-543.

. and M. Park. 2014. Real activities manipulation and auditors client retention decisions. The Accounting Review 89 (1): 367-401.

Kothari, S., A. Leone, and C. Wasley. 2005. Performance matched discretionary accrual measures. Journal of Accounting and Economics 39 (1): 163-197.

Krell, E. November 1, 2007. ERP crashes the SOX party. Business Finance, last accessed 12/5/2014 at http://businessfinancemag.com/technology/erp-crashes-sox-party

Kumar, V., R. Pollanen, and B. Maheshwari. 2008. Challenges in enhancing enterprise resource planning systems for compliance with Sarbanes-Oxley Act and analogous Canadian legislation. Management Research News 31 (10) 758-773.

Latamore, G. 2000. Why choosing the right database strategy is vital to plant and corporate operations. APICS March: 35-38.

Lawson Products, Inc. 2011. Annual report pursuant to section 13 or 15(d) of the securities exchange act of 1934. Des Plaines, IL: Lawson Products, Inc.

Masli, A., G. Peters, V. Richardson, and J. Sanchez. 2010. Examining the potential benefits of internal control monitoring technology. The Accounting Review 85 (3): 1001-1034. 
., V. Richardson, J. Sanchez, and R. Smith. 2011. The business value of IT: A synthesis and framework of archival research. Journal of Information Systems 25 (2) $81-116$.

Morris, J. 2011. The impact of enterprise resource planning (ERP) systems on the effectiveness of internal controls over financial reporting. Journal of Information Systems 25 (1) 129-157.

. and I. Laksmana. 2010. Measuring the impact of enterprise resource planning (ERP) systems on earnings management. Journal of Emerging Technologies in Accounting 71(1): 47-71.

Nicolaou, A. 2004. Firm performance effect in relation to the implementation and use of enterprise resource planning systems. Journal of Information Systems 18 (2) 79105.

Poston, R., and S. Grabski. 2001. Financial impacts of enterprise resource planning implementations. International Journal of Accounting Information Systems 2 (4): 271-94.

Public Company Accounting Oversight Board [PCAOB]. 2010. Auditing Standards Related to the Auditor's Assessment of and Response to Risk and Related Amendments to PCAOB Standards. http://pcaobus.org/Rules/Rulemaking/Docket \%20026/Release 2010-004 Risk As sessment.pdf

Rizzi, A. and R. Zamboni. 1999. Efficiency improvement in manual warehouses through ERP systems implementation and redesign of the logistics processes. Logistics Information Management 12 (5): 367-377.

Robey, D., J. W. Ross, and M. C. Boudreau. 2002. Learning to implement enterprise systems: An exploratory study of the dialectics of change. Journal of Management Information System 19 (1): 17-46.

Roychowdhury, S. 2006. Earnings management through real activities manipulation. Journal of Accounting and Economics 42: 335-370.

Singh, K., P. Best, M. Bojilov, and C. Blunt. 2014. Continuous auditing and continuous monitoring in ERP environments: Case studies of application implementations. Journal of Information Systems 28 (1): 287-310.

U.S. Congress. July 30, 2002. Sarbanes-Oxley Act of 2002 [SOX] Public Law 107-204. 107th Congress, available at: https:/www.sec.gov/about/laws/soa2002.pdf 
U.S. Securities and Exchange Commission [SEC]. January 27, 2000. Proposed Rule:

Supplementary Financial Information. http://www.sec.gov/rules/proposed/3442354.htm

Wright, S. and A. Wright. 2002. Information system assurance for enterprise resource planning systems: Implementation and unique risk considerations. Journal of Information Systems 16 (S-1): 99-113.

Yusuf, Y., A. Gunasekaran, and M.S. Abthorpe. 2004. Enterprise information systems project implementation: A case study of ERP in Rolls-Royce. International Journal of Production Economics 87: 251-266

Zang, A. 2012. Evidence on the Trade-Off between Real Activities Manipulation and accrual-Based Earnings Management. The Accounting Review 87 (2): 675-703.

Zhao, Y., K. Chen, Y. Zhang, and M. Davis. 2012. Takeover protection and managerial myopia: Evidence from real earnings management. Journal of Accounting and Public Policy 31: 109-135. 


\section{Appendix}

Variable Definitions

\begin{tabular}{|c|c|}
\hline Variable Names & Definitions \\
\hline EM & $\begin{array}{l}\text { Earnings management constructs ABSDA, REMDISC, REMPROD, } \\
\text { REMCASH, REM1 and REM2 as defined below }\end{array}$ \\
\hline ABSDA & $\begin{array}{l}\text { The absolute value of discretionary accruals computed as presented in } \\
\text { Kothari, Leone, and Wasley (2005). }\end{array}$ \\
\hline REMDISC & $\begin{array}{l}\text { The level of abnormal discretionary expenses, where discretionary expenses } \\
\text { are the sum of advertising expenses, R\&D expenses and SG\&A expenses. }\end{array}$ \\
\hline REMPROD & $\begin{array}{l}\text { The level of abnormal production costs, where production costs are defined } \\
\text { as the sum of cost of goods sold and the change in inventories. }\end{array}$ \\
\hline REMCASH & The level of abnormal cash flows from operations. \\
\hline REM1 & The sum of REMPROD and REMDISC \\
\hline REM2 & The sum of REMPROD, REMDISC and REMCASH \\
\hline ERP & $\begin{array}{l}\text { An indicator variable with value equal to } 1 \text { for the years following ERP } \\
\text { implementation, and } 0 \text { otherwise. }\end{array}$ \\
\hline $\mathrm{OCF}$ & Operating cash flows divided by total assets \\
\hline LGTA & The natural $\log$ of total assets. \\
\hline SOX & $\begin{array}{l}\text { An indicator variable with value equal to } 1 \text { for the years after } 2002 \text {, and } 0 \\
\text { otherwise. }\end{array}$ \\
\hline ROA & The ratio of net income to average total assets. \\
\hline AUD & $\begin{array}{l}\text { An indicator variable with value equal to } 1 \text { if firm is audited by a big } 4 \\
\text { accounting firm, and } 0 \text { otherwise. }\end{array}$ \\
\hline MTB & The market to book ratio \\
\hline LEV & The ratio of total liabilities to total assets. \\
\hline NOA & $\begin{array}{l}\text { An indicator variable that equals } 1 \text { if the net operating assets at the } \\
\text { beginning of the year divided by lagged sales is above the median of the } \\
\text { corresponding industry-year, and } 0 \text { otherwise. }\end{array}$ \\
\hline MKTSHARE & $\begin{array}{l}\text { The ratio of firms' total revenues to the total revenues of the corresponding } \\
\text { industry-year. }\end{array}$ \\
\hline INST & The percentage of institutional ownership at the beginning $f$ the year. \\
\hline$\% \mathrm{CL}$ & $\begin{array}{l}\text { Current liabilities excluding short-term debt as a percentage of total assets at } \\
\text { the beginning of the year. }\end{array}$ \\
\hline ZSCORE & Altman’s (1968) Zscore \\
\hline MANU & $\begin{array}{l}\text { An indicator variable equal to } 1 \text { if a firm's SIC code is greater than } 1999 \text { and } \\
\text { less than } 4000 \text {, and zero otherwise. }\end{array}$ \\
\hline AUDTEN & $\begin{array}{l}\text { The number of successive years (beginning in 1988) that the current auditor } \\
\text { has audited the firm's financial statements }\end{array}$ \\
\hline CYCLE & $\begin{array}{l}\text { The sum of days receivable and days inventory, less days payable at the } \\
\text { beginning of the year }\end{array}$ \\
\hline MTR & $\begin{array}{l}\text { The marginal tax rate, developed and provided by Professor John Graham } \\
\text { (http://faculty.fuqua.duke.edu/;jgraham/) }\end{array}$ \\
\hline ACCR & $\begin{array}{l}\text { Discretionary accruals computed as presented in Kothari, Leone, and } \\
\text { Wasley (2005) }\end{array}$ \\
\hline
\end{tabular}


Table 1 Sample Identification

Panel A: Summary of Sample Search

\begin{tabular}{cccc}
\hline Year & $\begin{array}{c}\text { Total } \\
\text { Documents }\end{array}$ & $\begin{array}{c}\text { Total } \\
\text { Documents } \\
\text { Traded } \\
\text { Companies }\end{array}$ & $\begin{array}{c}\text { Total } \\
\text { Documents } \\
\text { OTCPK }\end{array}$ \\
\hline 2002 & 150 & 57 & 93 \\
2003 & 141 & 63 & 78 \\
2004 & 170 & 77 & 93 \\
2005 & 173 & 97 & 76 \\
2006 & 226 & 115 & 111 \\
2007 & 240 & 126 & 114 \\
2008 & 100 & 66 & 34 \\
2009 & 256 & 168 & 88 \\
2010 & 245 & 155 & 90 \\
2011 & 259 & 178 & 81 \\
2012 & 260 & 200 & 60 \\
2013 & 309 & 258 & 51 \\
\hline \hline TOTAL & $\mathbf{2 5 2 9}$ & $\mathbf{1 5 6 0}$ & $\mathbf{9 6 9}$ \\
\hline
\end{tabular}

Panel B: Summary of Sample Selection Process

ERP adoptions disclosed in the annual reports Firms

Less firms adoption after 2011 168

Less financial institutions

Less firms missing -3 to +3 window data

Firms adopting ERP systems

109

Control firms not adopting ERP systems

109


Table 1 Continued

Panel C: Distribution of ERP Implementers by Industry

\begin{tabular}{lcc} 
Adopting Firms Represented by the Following SIC Code & & $\begin{array}{c}\text { Number } \\
\text { of Firms }\end{array}$ \\
\cline { 1 - 1 } (0000-1999)--Agriculture Mining and Construction & 3 \\
(2000-3999)--Manufacturing & 81 \\
(4000-4999)--Transportation and Utilities & 4 \\
(5000-5999)--Wholesale and Retail & 9 \\
(7000-9999)--Services & 12 \\
Total & \\
\cline { 2 - 3 }
\end{tabular}

Panel D: Distribution of ERP Implementations by Year

\begin{tabular}{c}
$\begin{array}{c}\text { Implementation } \\
\text { Year }\end{array}$ \\
\hline 2002 \\
2003 \\
2004 \\
2005 \\
2006 \\
2007 \\
2008 \\
2009 \\
2010 \\
2011 \\
Total
\end{tabular}

\begin{tabular}{cc}
$\begin{array}{c}\text { Number } \\
\text { of Firms }\end{array}$ & \% \\
\hline 7 & 6.4 \\
10 & 9.2 \\
8 & 7.3 \\
10 & 9.2 \\
19 & 17.4 \\
14 & 12.8 \\
11 & 10.1 \\
11 & 10.1 \\
18 & 16.5 \\
1 & 0.9 \\
\hline 109 & $100 \%$ \\
\hline
\end{tabular}


Table 2 Descriptive Statistics for Earnings Management Measures and Control Variables Panel A: Descriptive Statistics for ERP Implementers

\begin{tabular}{|c|c|c|c|c|c|c|c|c|c|c|c|c|}
\hline \multirow[b]{2}{*}{ Variable } & \multicolumn{6}{|c|}{ Pre Implementation Period } & \multicolumn{6}{|c|}{ Post Implementation Period } \\
\hline & $\mathrm{N}$ & Mean & Median & Std Dev & $25 \%$ & $75 \%$ & $\mathrm{~N}$ & Mean & Median & $\underline{\text { Std Dev }}$ & $25 \%$ & $75 \%$ \\
\hline$\overline{\mathrm{ABACC}}$ & 327 & 0.093 & 0.057 & 0.134 & 0.027 & 0.116 & 327 & 0.073 & 0.051 & 0.077 & 0.025 & 0.093 \\
\hline REMDISC & 327 & -0.01 & 0.013 & 0.198 & -0.096 & 0.139 & 327 & -0.042 & 0.017 & 0.316 & -0.09 & 0.128 \\
\hline PROD & 327 & 0.011 & -0.011 & 0.193 & -0.118 & 0.076 & 327 & -0.022 & -0.016 & 0.247 & -0.103 & 0.082 \\
\hline REM & & & & & & & & & & & & \\
\hline $\mathrm{CASH}$ & 327 & -0.045 & -0.053 & 0.126 & -0.106 & 0.01 & 327 & -0.042 & -0.045 & 0.110 & -0.094 & -0.005 \\
\hline REM1 & 327 & 0 & 0.014 & 0.324 & -0.174 & 0.185 & 327 & -0.064 & 0.008 & 0.532 & -0.19 & 0.185 \\
\hline REM2 & 327 & -0.045 & -0.045 & 0.365 & -0.249 & 0.142 & 327 & -0.106 & -0.038 & 0.592 & -0.237 & 0.141 \\
\hline LGTA & 327 & 6.06 & 6.087 & 1.669 & 4.979 & 7.392 & 327 & 6.359 & 6.407 & 1.584 & 5.299 & 7.634 \\
\hline SOX & 327 & 0.765 & 1 & 0.425 & 1 & 1 & 327 & 1 & 1 & 0.000 & 1 & 1 \\
\hline ROA & 327 & 0.012 & 0.042 & 0.153 & -0.004 & 0.082 & 327 & 0.003 & 0.032 & 0.129 & -0.019 & 0.083 \\
\hline AUD & 327 & 0.263 & 0 & 0.441 & 0 & 1 & 327 & 0.229 & 0 & 0.421 & 0 & 0 \\
\hline MTB & 327 & 3.058 & 2.122 & 4.764 & 1.351 & 3.446 & 327 & 2.469 & 1.733 & 2.489 & 1.029 & 3.166 \\
\hline LEV & 327 & 0.436 & 0.428 & 0.221 & 0.258 & 0.586 & 327 & 0.451 & 0.438 & 0.196 & 0.303 & 0.593 \\
\hline NOA & 327 & 0.737 & 1 & 0.441 & 0 & 1 & 327 & 0.706 & 1 & 0.456 & 0 & 1 \\
\hline SHARE & 327 & 0.05 & 0.006 & 0.134 & 0.001 & 0.035 & 327 & 0.049 & 0.007 & 0.128 & 0.001 & 0.026 \\
\hline INST & 327 & 0.642 & 0.647 & 0.367 & 0.411 & 0.883 & 327 & 0.701 & 0.755 & 0.364 & 0.505 & 0.875 \\
\hline$\% \mathrm{CL}$ & 327 & 0.242 & 0.208 & 0.149 & 0.138 & 0.298 & 327 & 0.214 & 0.195 & 0.116 & 0.142 & 0.248 \\
\hline ZSCORE & 327 & 6.116 & 3.723 & 6.908 & 2.26 & 7.17 & 327 & 4.182 & 3.194 & 4.891 & 1.912 & 5.651 \\
\hline MANU & 327 & 0.743 & 1 & 0.438 & 0 & 1 & 327 & 0.743 & 1 & 0.438 & 0 & 1 \\
\hline AUDTEN & 327 & 6.676 & 5 & 4.603 & 3 & 11 & 327 & 9.028 & 8 & 5.355 & 5 & 13 \\
\hline CYCLE & 327 & 117.915 & 97.294 & 91.536 & 65.214 & 151.978 & 327 & 116.805 & 97.692 & 91.186 & 57.713 & 140.748 \\
\hline MTR & 327 & 0.267 & 0.314 & 0.506 & 0.116 & 0.378 & 327 & 0.034 & 0.263 & 1.448 & 0.037 & 0.349 \\
\hline ACCR & 327 & -0.066 & 0.152 & -0.095 & -0.051 & -0.013 & 327 & -0.058 & 0.097 & -0.095 & -0.047 & -0.023 \\
\hline
\end{tabular}


Table 2 Panel A Continued

\begin{tabular}{|c|c|c|c|c|c|c|}
\hline \multirow{2}{*}{ Variable } & \multicolumn{6}{|c|}{ Pre and Post Implementation Periods Combined } \\
\hline & $\mathrm{N}$ & Mean & Median & Std Dev & $25 \%$ & $75 \%$ \\
\hline $\mathrm{ABACC}$ & 654 & 0.083 & 0.053 & 0.11 & 0.026 & 0.103 \\
\hline REMDISC & 654 & -0.026 & 0.014 & 0.264 & -0.093 & 0.13 \\
\hline \multicolumn{7}{|l|}{ REM } \\
\hline PROD & 654 & -0.006 & -0.014 & 0.222 & -0.107 & 0.077 \\
\hline \multicolumn{7}{|l|}{ REM } \\
\hline $\mathrm{CASH}$ & 654 & -0.044 & -0.049 & 0.118 & -0.100 & 0.01 \\
\hline REM1 & 654 & -0.032 & 0.009 & 0.441 & -0.185 & 0.179 \\
\hline REM2 & 654 & -0.075 & -0.039 & 0.492 & -0.243 & 0.128 \\
\hline LGTA & 654 & 6.209 & 6.251 & 1.632 & 5.116 & 7.486 \\
\hline SOX & 654 & 0.881 & 1 & 0.324 & 1 & 1 \\
\hline ROA & 654 & 0.007 & 0.037 & 0.141 & -0.01 & 0.08 \\
\hline AUD & 654 & 0.246 & 0 & 0.431 & 0 & 0 \\
\hline MTB & 654 & 2.764 & 1.984 & 3.81 & 1.169 & 3.167 \\
\hline LEV & 654 & 0.444 & 0.43 & 0.209 & 0.28 & 0.586 \\
\hline NOA & 654 & 0.722 & 1 & 0.448 & 0 & 1 \\
\hline \multicolumn{7}{|l|}{ MKT } \\
\hline SHARE & 654 & 0.049 & 0.007 & 0.131 & 0.001 & 0.036 \\
\hline INST & 654 & 0.671 & 0.726 & 0.366 & 0.451 & 0.885 \\
\hline$\% \mathrm{CL}$ & 654 & 0.228 & 0.203 & 0.134 & 0.138 & 0.288 \\
\hline ZSCORE & 654 & 5.149 & 3.447 & 6.059 & 2.055 & 6.012 \\
\hline MANU & 654 & 0.743 & 1 & 0.438 & 0 & 1 \\
\hline \multicolumn{7}{|l|}{ AUD } \\
\hline TEN & 654 & 7.852 & 7 & 5.126 & 4 & 12 \\
\hline CYCLE & 654 & 117.36 & 97.493 & 91.293 & 62.028 & 154.308 \\
\hline MTR & 654 & 0.151 & 0.289 & 0.977 & 0.077 & 0.371 \\
\hline $\mathrm{ACCR}$ & 654 & -0.062 & 0.127 & -0.095 & -0.049 & -0.016 \\
\hline
\end{tabular}


Table 2 Continued

Panel B: Descriptive Statistics for Control Group

\begin{tabular}{|c|c|c|c|c|c|c|c|c|c|c|c|c|}
\hline \multirow[b]{2}{*}{ Variable } & \multicolumn{3}{|c|}{ Pre Implementation Period } & \multicolumn{9}{|c|}{ Post Implementation Period } \\
\hline & $\mathrm{N}$ & Mean & Median & Std Dev & $25 \%$ & $75 \%$ & $\mathrm{~N}$ & Mean & Median & $\underline{\text { Std Dev }}$ & $25 \%$ & $75 \%$ \\
\hline $\mathrm{ABACC}$ & 327 & 0.091 & 0.054 & 0.185 & 0.027 & 0.09 & 327 & 0.087 & 0.053 & 0.144 & 0.026 & 0.093 \\
\hline REMDISC & 327 & -0.012 & 0.004 & 0.232 & -0.104 & 0.132 & 327 & -0.007 & 0.027 & 0.240 & -0.08 & 0.128 \\
\hline REM & & & & & & & & & & & & \\
\hline PROD & 327 & 0.012 & -0.021 & 0.174 & -0.123 & 0.054 & 327 & 0.012 & -0.018 & 0.209 & -0.104 & 0.082 \\
\hline REM & & & & & & & & & & & & \\
\hline CASH & 327 & -0.047 & -0.063 & 0.146 & -0.126 & -0.007 & 327 & -0.047 & -0.06 & 0.238 & -0.122 & -0.005 \\
\hline REM1 & 327 & -0.019 & -0.006 & 0.345 & -0.206 & 0.186 & 327 & 0.006 & 0.014 & 0.379 & -0.187 & 0.185 \\
\hline REM2 & 327 & -0.067 & -0.069 & 0.393 & -0.28 & 0.136 & 327 & -0.042 & -0.038 & 0.509 & -0.254 & 0.141 \\
\hline LGTA & 327 & 6.004 & 6.123 & 1.689 & 4.866 & 7.238 & 327 & 6.357 & 6.421 & 1.735 & 5.346 & 7.634 \\
\hline SOX & 327 & 0.765 & 1 & 0.425 & 1 & 1 & 327 & 1 & 1 & 0.000 & 1 & 1 \\
\hline ROA & 327 & 0.016 & 0.048 & 0.166 & 0.006 & 0.089 & 327 & -0.006 & 0.041 & 0.2 & 0.002 & 0.083 \\
\hline AUD & 327 & 0.162 & 0 & 0.369 & 0 & 0 & 327 & 0.153 & 0 & 0.36 & 0 & 0 \\
\hline MTB & 327 & 2.79 & 2.124 & 3.891 & 1.345 & 3.807 & 327 & 2.595 & 1.944 & 2.529 & 1.24 & 3.166 \\
\hline LEV & 327 & 0.426 & 0.408 & 0.219 & 0.255 & 0.576 & 327 & 0.44 & 0.428 & 0.226 & 0.255 & 0.593 \\
\hline NOA & 327 & 0.679 & 1 & 0.468 & 0 & 1 & 327 & 0.688 & 1 & 0.464 & 0 & 1 \\
\hline MKT & & & & & & & & & & & & \\
\hline SHARE & 327 & 0.025 & 0.006 & 0.054 & 0.001 & 0.022 & 327 & 0.035 & 0.006 & 0.088 & 0.001 & 0.026 \\
\hline INST & 327 & 0.604 & 0.594 & 0.959 & 0.148 & 0.837 & 327 & 0.551 & 0.66 & 0.38 & 0.132 & 0.875 \\
\hline$\% \mathrm{CL}$ & 327 & 0.231 & 0.2 & 0.148 & 0.129 & 0.29 & 327 & 0.212 & 0.182 & 0.149 & 0.114 & 0.248 \\
\hline ZSCORE & 327 & 5.431 & 3.803 & 6.197 & 2.148 & 6.674 & 327 & 4.15 & 3.318 & 5.834 & 1.933 & 5.651 \\
\hline MANU & 327 & 0.743 & 1 & 0.438 & 0 & 1 & 327 & 0.743 & 1 & 0.438 & 0 & 1 \\
\hline AUDTEN & 327 & 7.043 & 6 & 4.545 & 3 & 10 & 327 & 9.245 & 8 & 5.573 & 5 & 13 \\
\hline CYCLE & 327 & 100.406 & 92.624 & 70.436 & 41.796 & 145.548 & 327 & 100.068 & 93.14 & 67.761 & 45.078 & 140.748 \\
\hline MTR & 327 & 0.406 & 0.307 & 1.73 & 0.092 & 0.372 & 327 & 0.235 & 0.264 & 1.011 & 0.09 & 0.349 \\
\hline ACCR & 327 & -0.059 & 0.2 & -0.083 & -0.051 & -0.013 & 327 & -0.064 & 0.161 & -0.099 & -0.054 & -0.023 \\
\hline
\end{tabular}


Table 2 Panel B Continued

\begin{tabular}{|c|c|c|c|c|c|c|}
\hline \multirow[b]{2}{*}{ Variable } & \multicolumn{6}{|c|}{ Pre and Post Implementation Periods Combined } \\
\hline & $\mathrm{N}$ & Mean & $\underline{\text { Median }}$ & $\underline{\text { Std Dev }}$ & $25 \%$ & $75 \%$ \\
\hline ABACC & 654 & 0.089 & 0.053 & 0.166 & 0.027 & 0.093 \\
\hline REMDISC & 654 & -0.01 & 0.016 & 0.236 & -0.088 & 0.129 \\
\hline REMPROD & 654 & 0.012 & -0.02 & 0.192 & -0.114 & 0.067 \\
\hline REMCASH & 654 & -0.047 & -0.062 & 0.197 & -0.124 & -0.006 \\
\hline REM1 & 654 & -0.025 & 0.006 & 0.548 & -0.203 & 0.185 \\
\hline REM2 & 654 & -0.073 & -0.048 & 0.677 & -0.264 & 0.136 \\
\hline LGTA & 654 & 6.18 & 6.27 & 1.72 & 5.035 & 7.411 \\
\hline SOX & 654 & 0.881 & 1 & 0.324 & 1 & 1 \\
\hline ROA & 654 & 0.005 & 0.044 & 0.184 & 0.006 & 0.087 \\
\hline AUD & 654 & 0.157 & 0 & 0.365 & 0 & 0 \\
\hline МТB & 654 & 2.693 & 2.012 & 3.28 & 1.294 & 3.525 \\
\hline LEV & 654 & 0.433 & 0.415 & 0.222 & 0.255 & 0.581 \\
\hline NOA & 654 & 0.683 & 1 & 0.465 & 0 & 1 \\
\hline MKTSHARE & 654 & 0.03 & 0.006 & 0.073 & 0.001 & 0.024 \\
\hline INST & 654 & 0.577 & 0.64 & 0.73 & 0.136 & 0.868 \\
\hline$\% \mathrm{CL}$ & 654 & 0.222 & 0.188 & 0.148 & 0.123 & 0.273 \\
\hline ZSCORE & 654 & 4.79 & 3.554 & 6.048 & 2.09 & 6.053 \\
\hline MANU & 654 & 0.743 & 1 & 0.438 & 0 & 1 \\
\hline AUDTEN & 654 & 8.144 & 7 & 5.2 & 4 & 12 \\
\hline CYCLE & 654 & 100.237 & 93.111 & 69.059 & 43.165 & 143.22 \\
\hline MTR & 654 & 0.32 & 0.285 & 1.418 & 0.091 & 0.367 \\
\hline ACCR & 654 & -0.062 & 0.181 & -0.091 & -0.053 & -0.019 \\
\hline
\end{tabular}


Table 2 Continued

Panel C - Tests of Differences in Control Variable Means: ERP Implementers versus Control Group

\begin{tabular}{|c|c|c|c|c|c|c|}
\hline Variable & $\mathrm{n}$ & Mean & Paired t-test $\mathrm{n}$ & Mean Difference & t-value & $p$-value \\
\hline $\mathrm{OCF}$ & $\begin{array}{l}\text { ERP Implementer } \\
\text { Control }\end{array}$ & $\begin{array}{l}0.079 \\
0.072\end{array}$ & 654 & -0.007 & -0.530 & 0.599 \\
\hline LGTA & $\begin{array}{l}\text { ERP Implementer } \\
\text { Control }\end{array}$ & $\begin{array}{l}6.060 \\
6.004\end{array}$ & 654 & -0.056 & -0.430 & 0.668 \\
\hline SOX & $\begin{array}{l}\text { ERP Implementer } \\
\text { Control }\end{array}$ & $\begin{array}{l}0.765 \\
0.758\end{array}$ & 654 & -0.006 & -0.180 & 0.855 \\
\hline ROA & $\begin{array}{l}\text { ERP Implementer } \\
\text { Control }\end{array}$ & $\begin{array}{l}0.012 \\
0.016\end{array}$ & 654 & 0.005 & -0.380 & 0.703 \\
\hline AUD & $\begin{array}{l}\text { ERP Implementer } \\
\text { Control }\end{array}$ & $\begin{array}{l}0.263 \\
0.162\end{array}$ & 654 & -0.101 & -3.170 & $0.002 * * *$ \\
\hline MTB & $\begin{array}{l}\text { ERP Implementer } \\
\text { Control }\end{array}$ & $\begin{array}{l}3.058 \\
2.790\end{array}$ & 654 & -0.268 & -0.790 & 0.431 \\
\hline LEV & $\begin{array}{l}\text { ERP Implementer } \\
\text { Control }\end{array}$ & $\begin{array}{l}0.436 \\
0.426\end{array}$ & 654 & -0.010 & -0.600 & 0.550 \\
\hline NOA & $\begin{array}{l}\text { ERP Implementer } \\
\text { Control }\end{array}$ & $\begin{array}{l}0.737 \\
0.679\end{array}$ & 654 & -0.058 & -1.630 & 0.103 \\
\hline MKTSHARE & $\begin{array}{l}\text { ERP Implementer } \\
\text { Control }\end{array}$ & $\begin{array}{l}0.050 \\
0.025\end{array}$ & 654 & -0.025 & -3.140 & $0.002 * * *$ \\
\hline INST & $\begin{array}{l}\text { ERP Implementer } \\
\text { Control }\end{array}$ & $\begin{array}{l}0.642 \\
0.604\end{array}$ & 654 & -0.038 & -0.670 & 0.506 \\
\hline$\% \mathrm{CL}$ & $\begin{array}{l}\text { ERP Implementer } \\
\text { Control }\end{array}$ & $\begin{array}{l}0.242 \\
0.231\end{array}$ & 654 & -0.010 & -0.880 & 0.381 \\
\hline ZSCORE & $\begin{array}{l}\text { ERP Implementer } \\
\text { Control }\end{array}$ & $\begin{array}{l}6.116 \\
5.431\end{array}$ & 654 & -0.685 & -1.330 & 0.183 \\
\hline
\end{tabular}


Table 2 Continued

Panel C - Tests of Differences in Control Variable Means: ERP Implementers versus Control Group

\begin{tabular}{|c|c|c|c|c|c|c|}
\hline Variable & $\mathrm{n}$ & Mean & & $\begin{array}{l}\text { Mean } \\
\text { Difference }\end{array}$ & t-value & $p$-value \\
\hline MANU & $\begin{array}{l}\text { ERP Implementer } \\
\text { Control }\end{array}$ & $\begin{array}{l}0.743 \\
0.743\end{array}$ & 654 & 0.000 & 0.000 & 1.000 \\
\hline AUDTEN & $\begin{array}{l}\text { ERP Implementer } \\
\text { Control }\end{array}$ & $\begin{array}{l}6.676 \\
7.043\end{array}$ & 654 & 0.367 & -1.030 & 0.305 \\
\hline CYCLE & $\begin{array}{l}\text { ERP Implementer } \\
\text { Control }\end{array}$ & $\begin{array}{l}117.915 \\
100.406\end{array}$ & 654 & -17.510 & -2.740 & $0.006 * * *$ \\
\hline MTR & $\begin{array}{l}\text { ERP Implementer } \\
\text { Control }\end{array}$ & $\begin{array}{l}0.267 \\
0.406\end{array}$ & 654 & 0.139 & -1.390 & 0.164 \\
\hline ACCR & $\begin{array}{l}\text { ERP Implementer } \\
\text { Control }\end{array}$ & $\begin{array}{l}-0.066 \\
-0.059\end{array}$ & 654 & 0.007 & 0.480 & 0.631 \\
\hline
\end{tabular}

$\mathrm{t}$ statistics in parentheses. Significance is indicated by $* p<0.10, * * p<0.05, * * * p<0.01$ 
Table 3 Pearson Correlations for Model Variables

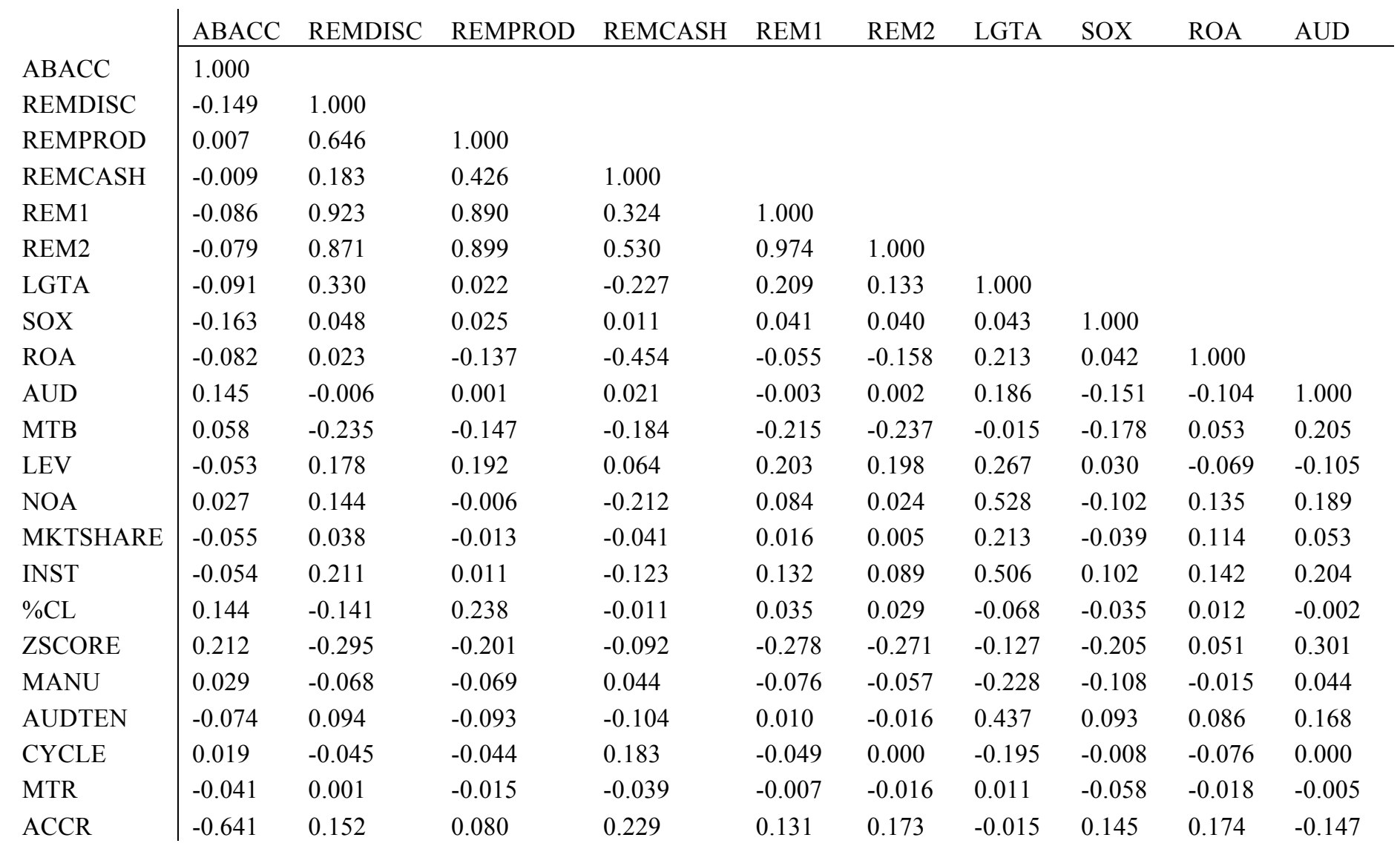


Table 3 Continued

\begin{tabular}{|c|c|c|c|c|c|c|c|c|c|c|c|c|}
\hline & MTB & LEV & NOA & $\begin{array}{l}\text { MKT } \\
\text { SHARE }\end{array}$ & INST & $\% \mathrm{CL}$ & $\begin{array}{l}\text { Z } \\
\text { SCORE }\end{array}$ & MANU & $\begin{array}{l}\text { AUD } \\
\text { TEN }\end{array}$ & CYCLE & MTR & ACCR \\
\hline MTB & 1.000 & & & & & & & & & & & \\
\hline LEV & -0.100 & 1.000 & & & & & & & & & & \\
\hline $\begin{array}{l}\text { NOA } \\
\text { MKT }\end{array}$ & 0.125 & -0.043 & 1.000 & & & & & & & & & \\
\hline SHARE & -0.041 & 0.087 & 0.094 & 1.000 & & & & & & & & \\
\hline INST & 0.007 & -0.014 & 0.401 & 0.129 & 1.000 & & & & & & & \\
\hline$\% \mathrm{CL}$ & 0.137 & 0.295 & 0.070 & 0.068 & -0.093 & 1.000 & & & & & & \\
\hline ZSCORE & 0.460 & -0.512 & 0.047 & -0.070 & 0.016 & -0.020 & 1.000 & & & & & \\
\hline MANU & 0.012 & -0.252 & 0.033 & -0.001 & -0.025 & -0.140 & 0.141 & 1.000 & & & & \\
\hline AUDTEN & -0.071 & 0.106 & 0.244 & 0.226 & 0.266 & -0.078 & -0.120 & -0.057 & 1.000 & & & \\
\hline CYCLE & -0.028 & -0.131 & -0.099 & -0.003 & -0.032 & -0.114 & 0.047 & 0.191 & -0.030 & 1.000 & & \\
\hline MTR & -0.002 & 0.076 & 0.010 & -0.075 & 0.013 & 0.021 & 0.013 & -0.052 & -0.042 & -0.063 & 1.000 & \\
\hline ACCR & -0.059 & -0.014 & -0.057 & 0.070 & 0.053 & -0.015 & -0.187 & 0.001 & 0.046 & 0.063 & 0.006 & 1.000 \\
\hline
\end{tabular}


Table 4 Univariate Tests of Equality of Means - Earnings Management Measures

Panel A - Comparison of Earnings Management Measures of ERP Implementers' Pre and Post Implementation

\begin{tabular}{|c|c|c|c|c|c|c|c|c|c|c|}
\hline \multicolumn{11}{|c|}{ Implementers } \\
\hline & $\begin{array}{l}\text { Pre- } \\
\text { Imp }\end{array}$ & $\begin{array}{l}\mathrm{RP} \\
\text { mentation }\end{array}$ & & $\begin{array}{l}\text { Post } \\
\text { Impl }\end{array}$ & $\begin{array}{l}\mathrm{RP} \\
\text { nentatio }\end{array}$ & & & & & \\
\hline Variable & $\mathrm{n}$ & Mean & $\begin{array}{l}\text { Std. } \\
\text { Dev. }\end{array}$ & $\mathrm{n}$ & Mean & $\begin{array}{l}\text { Std. } \\
\text { Dev }\end{array}$ & $\begin{array}{l}\text { Mean } \\
\text { Difference }\end{array}$ & $\begin{array}{l}\text { Std. Error } \\
\text { on Mean } \\
\text { Difference }\end{array}$ & t-value & $\begin{array}{l}\text { Prob. } \\
\operatorname{Pr}(|T|=|t|)\end{array}$ \\
\hline ABSDA & 327 & 0.093 & 0.134 & 327 & 0.073 & 0.077 & 0.0201 & 0.009 & 2.353 & 0.018 \\
\hline REMDISC & 327 & -0.010 & 0.198 & 327 & -0.042 & 0.316 & 0.0315 & 0.021 & 1.530 & 0.126 \\
\hline REMPROD & 327 & 0.011 & 0.193 & 327 & -0.022 & 0.247 & 0.0327 & 0.017 & 1.886 & 0.059 \\
\hline REMCASH & 327 & -0.045 & 0.126 & 327 & -0.042 & 0.110 & -0.0028 & 0.009 & -0.308 & 0.758 \\
\hline REM1 & 327 & 0.000 & 0.324 & 327 & -0.064 & 0.532 & 0.0642 & 0.034 & 1.865 & 0.062 \\
\hline REM2 & 327 & -0.045 & 0.365 & 327 & -0.106 & 0.592 & 0.0614 & 0.038 & 1.597 & 0.101 \\
\hline
\end{tabular}

Panel B: Comparison of Earnings Management Measures:

Implementers versus Control Group - Pre Implementation

\begin{tabular}{|c|c|c|c|c|c|c|c|c|c|c|}
\hline \multirow[b]{2}{*}{ Variable } & \multicolumn{3}{|c|}{ Control Group } & \multicolumn{3}{|c|}{ ERP Adopters } & \multirow[b]{2}{*}{$\begin{array}{l}\text { Mean } \\
\text { Difference }\end{array}$} & \multirow[b]{2}{*}{$\begin{array}{l}\text { Std. Error of } \\
\text { Mean } \\
\text { Difference }\end{array}$} & \multirow[b]{2}{*}{ t-value } & \multirow[b]{2}{*}{$\begin{array}{l}\text { Prob. } \\
\operatorname{Pr}(|\mathrm{T}|=|\mathrm{t}|)\end{array}$} \\
\hline & $\mathrm{n}$ & Mean & $\begin{array}{l}\text { Std. } \\
\text { Dev. }\end{array}$ & $\mathrm{n}$ & Mean & $\begin{array}{l}\text { Std. } \\
\text { Dev }\end{array}$ & & & & \\
\hline ABSDA & 327 & 0.091 & 0.185 & 327 & 0.093 & 0.134 & -0.002 & 0.013 & -0.146 & 0.884 \\
\hline REMDISC & 327 & -0.012 & 0.232 & 327 & -0.010 & 0.198 & -0.002 & 0.017 & -0.124 & 0.901 \\
\hline REMPROD & 327 & -0.047 & 0.146 & 327 & -0.045 & 0.126 & -0.002 & 0.011 & -0.215 & 0.830 \\
\hline REMCASH & 327 & 0.012 & 0.174 & 327 & 0.011 & 0.193 & 0.001 & 0.014 & 0.047 & 0.962 \\
\hline REM1 & 327 & -0.019 & 0.344 & 327 & 0.000 & 0.324 & -0.019 & 0.026 & -0.761 & 0.447 \\
\hline REM2 & 327 & -0.067 & 0.392 & 327 & -0.045 & 0.365 & -0.122 & 0.029 & -0.748 & 0.454 \\
\hline
\end{tabular}


Table 4 Continued

Panel C: Comparison of Earnings Management Measures:

Implementers versus Control Group - Post Implementation

\begin{tabular}{|c|c|c|c|c|c|c|c|c|c|c|}
\hline \multirow[b]{2}{*}{ Variable } & \multicolumn{3}{|c|}{ Control Group } & \multicolumn{3}{|c|}{ ERP Adopters } & \multirow[b]{2}{*}{$\begin{array}{l}\text { Mean } \\
\text { Difference }\end{array}$} & \multirow[b]{2}{*}{$\begin{array}{l}\text { Std. Error of } \\
\text { Mean } \\
\text { Difference }\end{array}$} & \multirow[b]{2}{*}{ t-value } & \multirow[b]{2}{*}{$\begin{array}{l}\text { Prob. } \\
\operatorname{Pr}(|\mathrm{T}|=|\mathrm{t}|)\end{array}$} \\
\hline & $\mathrm{n}$ & Mean & $\begin{array}{l}\text { Std. } \\
\text { Dev. }\end{array}$ & $\mathrm{n}$ & Mean & $\begin{array}{l}\text { Std. } \\
\text { Dev }\end{array}$ & & & & \\
\hline ABSDA & 327 & 0.086 & 0.144 & 327 & 0.073 & 0.077 & 0.014 & 0.009 & 1.490 & 0.126 \\
\hline REMDISC & 327 & -0.007 & 0.240 & 327 & -0.042 & 0.317 & 0.035 & 0.022 & 1.602 & 0.108 \\
\hline REMPROD & 327 & 0.012 & 0.209 & 327 & -0.022 & 0.247 & 0.034 & 0.018 & 1.917 & 0.055 \\
\hline REMCASH & 327 & -0.047 & 0.238 & 327 & -0.042 & 0.110 & -0.005 & 0.015 & -0.358 & 0.720 \\
\hline REM1 & 327 & 0.006 & 0.379 & 327 & -0.064 & 0.532 & 0.070 & 0.036 & 1.925 & 0.054 \\
\hline REM2 & 327 & -0.042 & 0.509 & 327 & -0.106 & 0.592 & 0.064 & 0.043 & 1.490 & 0.136 \\
\hline
\end{tabular}


Table 5 Regression Analysis of Earnings Management: Pre versus Post ERP Implementation

\begin{tabular}{|c|c|c|c|c|c|c|c|c|}
\hline & \multicolumn{2}{|l|}{ ABSDA } & \multicolumn{2}{|l|}{ REMDISC } & \multicolumn{2}{|l|}{ REMPROD } & \multicolumn{2}{|l|}{ REMCASH } \\
\hline & Coeff. & t-value & Coeff. & $\mathrm{t}$-value & Coeff. & t-value & Coeff. & t-value \\
\hline ERP & $-0.014 * *$ & $(-2.02)$ & $-0.097 * * *$ & $(-3.29)$ & $-0.057 * * *$ & $(-2.63)$ & -0.009 & $(-0.84)$ \\
\hline LGTA & -0.003 & $(-0.80)$ & $0.048 * * *$ & (4.34) & 0.011 & $(1.30)$ & -0.007 & $(-1.57)$ \\
\hline ROA & $-0.257 * * *$ & $(-6.49)$ & -0.062 & $(-0.59)$ & $-0.195 * *$ & $(-2.26)$ & $-0.358 * * *$ & $(-6.50)$ \\
\hline AUD & 0.005 & $(0.68)$ & 0.016 & $(0.71)$ & $0.034 *$ & $(1.90)$ & 0.011 & $(1.15)$ \\
\hline MTB & -0.000 & $(-0.49)$ & $-0.010^{*}$ & $(-1.76)$ & -0.007 & $(-1.27)$ & $-0.005^{*}$ & $(-1.75)$ \\
\hline LEV & -0.017 & $(-0.91)$ & 0.061 & $(0.89)$ & 0.046 & $(0.71)$ & 0.034 & $(1.04)$ \\
\hline NOA & 0.008 & $(1.00)$ & 0.008 & $(0.27)$ & -0.009 & $(-0.34)$ & $-0.023^{*}$ & $(-1.80)$ \\
\hline MKTSHARE & -0.013 & $(-0.71)$ & $-0.059 *$ & $(-1.83)$ & -0.044 & $(-1.02)$ & 0.028 & $(1.28)$ \\
\hline INST & 0.007 & $(0.87)$ & $0.053 * *$ & $(2.45)$ & 0.026 & $(1.27)$ & 0.009 & $(0.73)$ \\
\hline$\% \mathrm{CL}$ & $0.112 * * *$ & $(2.61)$ & $-0.258 * * *$ & $(-3.41)$ & $0.392 * * *$ & $(3.55)$ & 0.012 & $(0.27)$ \\
\hline ZSCORE & $0.002 * *$ & $(2.31)$ & $-0.008 * * *$ & $(-2.60)$ & -0.004 & $(-1.54)$ & -0.000 & $(-0.02)$ \\
\hline MANUF & -0.003 & $(-0.36)$ & 0.022 & $(1.46)$ & 0.011 & $(0.61)$ & 0.005 & $(0.48)$ \\
\hline AUDTEN & 0.000 & $(0.48)$ & $-0.004 * *$ & $(-2.24)$ & $-0.006^{* * *}$ & $(-3.34)$ & -0.001 & $(-0.73)$ \\
\hline CYCLE & -0.000 & $(-0.33)$ & -0.000 & $(-0.48)$ & -0.000 & $(-0.49)$ & $0.000 * *$ & $(2.32)$ \\
\hline MTR & 0.012 & $(0.78)$ & $-0.144 * * *$ & $(-2.82)$ & $-0.151 * * *$ & $(-2.90)$ & $-0.083 * * *$ & $(-3.59)$ \\
\hline ACCR & & & $0.269 * * *$ & (3.38) & $0.186^{* *}$ & $(2.21)$ & & \\
\hline YEAR & YES & & YES & & YES & & YES & \\
\hline $\begin{array}{l}\text { DUMMIES } \\
\text { (Intercept) }\end{array}$ & 0.112 & $(1.52)$ & 0.028 & $(0.20)$ & -0.110 & $(-1.24)$ & -0.111 & $(-1.30)$ \\
\hline $\mathrm{N}$ & 654 & & 654 & & 654 & & 654 & \\
\hline adj. R2 & 0.239 & & 0.233 & & 0.136 & & 0.293 & \\
\hline
\end{tabular}

$\mathrm{t}$ statistics in parentheses

Significance is indicated by $* p \leq 0.10, * * p \leq 0.05, * * * p \leq 0.01$, based on firm-level clustered errors 
Table 5 Continued

\begin{tabular}{lllll}
\hline & REM1 & & REM2 & \\
& Coeff. & t-value & Coeff. & t-value \\
\hline ERP & $-0.154^{* * *}$ & $(-3.17)$ & $-0.166^{* * *}$ & $(-3.00)$ \\
LGTA & $0.060^{* * *}$ & $(3.15)$ & $0.052^{* *}$ & $(2.38)$ \\
ROA & -0.257 & $(-1.43)$ & $-0.565^{* * *}$ & $(-2.76)$ \\
AUD & 0.050 & $(1.32)$ & 0.052 & $(1.27)$ \\
MTB & -0.017 & $(-1.56)$ & -0.021 & $(-1.60)$ \\
LEV & 0.107 & $(0.86)$ & 0.101 & $(0.69)$ \\
NOA & -0.001 & $(-0.02)$ & -0.035 & $(-0.58)$ \\
MKTSHARE & $-0.103 *$ & $(-1.69)$ & -0.054 & $(-0.76)$ \\
INST & $0.079 * *$ & $(2.14)$ & $0.098^{* *}$ & $(2.53)$ \\
\%CL & 0.134 & $(0.80)$ & 0.151 & $(0.84)$ \\
ZSCORE & $-0.012^{* *}$ & $(-2.23)$ & $-0.015 * *$ & $(-2.27)$ \\
MANUF & 0.033 & $(1.14)$ & 0.038 & $(1.17)$ \\
AUDTEN & $-0.009 * * *$ & $(-3.07)$ & $-0.009 * * *$ & $(-2.71)$ \\
CYCLE & -0.000 & $(-0.56)$ & 0.000 & $(0.43)$ \\
MTR & $-0.295^{* * *}$ & $(-3.09)$ & $-0.347 * * *$ & $(-3.24)$ \\
ACCR & $0.455^{* * *}$ & $(3.07)$ & & \\
YEAR & YES & & YES & \\
DUMMIES & & & & \\
(Intercept) & -0.082 & $(-0.43)$ & -0.221 & $(-1.18)$ \\
\hline N & 654 & & 654 & \\
adj. R2 & 0.157 & & 0.151 & \\
\hline
\end{tabular}

$\mathrm{t}$ statistics in parentheses

Significance is indicated by $* p \leq 0.10, * * p \leq 0.05, * * * p \leq 0.01$, based on firm-level clustered errors 
Table 6 Regression Analysis of Earnings Management for Suspect Firms: Pre versus Post ERP Implementation

\begin{tabular}{|c|c|c|c|c|c|c|c|c|}
\hline & \multicolumn{2}{|l|}{ ABSDA } & \multicolumn{2}{|l|}{ REMDISC } & \multicolumn{2}{|c|}{ REMPROD } & \multicolumn{2}{|l|}{ REMCASH } \\
\hline & Coeff. & t-value & Coeff. & t-value & Coeff. & t-value & Coeff. & t-value \\
\hline ERP & -0.011 & $(-0.98)$ & $-0.105 * *$ & $(-2.42)$ & $-0.073 *$ & $(-1.69)$ & -0.027 & $(-1.64)$ \\
\hline LGTA & $-0.008^{*}$ & $(-1.78)$ & $0.042 * *$ & $(2.23)$ & $0.029 *$ & (1.77) & 0.004 & $(0.63)$ \\
\hline ROA & 0.465 & $(1.55)$ & 0.164 & $(0.43)$ & -0.228 & $(-0.60)$ & -0.027 & $(-0.14)$ \\
\hline AUD & 0.005 & $(0.36)$ & $0.083 * *$ & $(2.11)$ & $0.093 * *$ & $(2.36)$ & 0.022 & $(1.03)$ \\
\hline MTB & $-0.006 * * *$ & $(-2.91)$ & -0.006 & $(-0.50)$ & -0.002 & $(-0.24)$ & -0.004 & $(-1.06)$ \\
\hline LEV & 0.038 & $(1.40)$ & 0.013 & $(0.15)$ & -0.103 & $(-0.99)$ & -0.064 & $(-1.42)$ \\
\hline NOA & $0.024 *$ & (1.87) & $0.081^{*}$ & (1.66) & 0.066 & $(1.47)$ & $-0.072 * * *$ & $(-3.63)$ \\
\hline MKTSHARE & $-0.096^{*}$ & $(-1.83)$ & $-0.289 * * *$ & $(-2.94)$ & -0.138 & $(-1.11)$ & -0.054 & $(-1.03)$ \\
\hline INST & -0.009 & $(-0.59)$ & 0.029 & $(0.88)$ & -0.046 & $(-1.33)$ & $0.034 * * *$ & (2.69) \\
\hline$\% \mathrm{CL}$ & -0.004 & $(-0.10)$ & -0.079 & $(-0.59)$ & $0.416 * * *$ & $(3.27)$ & $0.227 * * *$ & $(5.33)$ \\
\hline ZSCORE & $0.004 * * *$ & $(2.64)$ & -0.006 & $(-1.19)$ & -0.007 & $(-1.21)$ & $-0.006 * * *$ & $(-3.35)$ \\
\hline MANUF & -0.003 & $(-0.24)$ & 0.033 & $(0.84)$ & 0.047 & $(1.28)$ & 0.015 & $(0.93)$ \\
\hline AUDTEN & -0.000 & $(-0.12)$ & $-0.006^{*}$ & $(-1.73)$ & $-0.009 * *$ & $(-2.60)$ & 0.001 & $(0.47)$ \\
\hline CYCLE & -0.000 & $(-1.35)$ & 0.000 & $(0.89)$ & -0.000 & $(-1.12)$ & $0.000 * *$ & (1.98) \\
\hline MTR & $-0.036^{*}$ & $(-1.76)$ & -0.026 & $(-0.39)$ & 0.002 & $(0.03)$ & 0.003 & $(0.08)$ \\
\hline ACCR & & & $0.651^{*}$ & $(1.95)$ & $1.093 * * *$ & $(3.46)$ & & \\
\hline YEAR & YES & & YES & & YES & & YES & \\
\hline $\begin{array}{l}\text { DUMMIES } \\
\text { (Intercept) }\end{array}$ & $0.083 * *$ & $(2.07)$ & -0.165 & $(-1.16)$ & -0.110 & $(-0.82)$ & -0.047 & $(-0.82)$ \\
\hline $\mathrm{N}$ & 137 & & 137 & & 137 & & 137 & \\
\hline adj. R2 & 0.179 & & 0.190 & & 0.311 & & 0.213 & \\
\hline
\end{tabular}

$\mathrm{t}$ statistics in parentheses

Significance is indicated by $* p \leq 0.10, * * p \leq 0.05, * * * p \leq 0.01$, based on firm-level clustered errors 
Table 6 Continued

\begin{tabular}{lllll}
\hline & REM1 & & REM2 & \\
& Coeff. & t-value & Coeff. & t-value \\
\hline ERP & $-0.178^{* *}$ & $(-2.15)$ & $-0.237^{* *}$ & $(-2.43)$ \\
LGTA & $0.071^{* *}$ & $(2.17)$ & $0.079^{*}$ & $(1.98)$ \\
ROA & -0.064 & $(-0.09)$ & 0.553 & $(0.70)$ \\
AUD & $0.176^{* *}$ & $(2.44)$ & $0.220^{* *}$ & $(2.42)$ \\
MTB & -0.008 & $(-0.40)$ & -0.009 & $(-0.35)$ \\
LEV & -0.089 & $(-0.51)$ & -0.226 & $(-1.14)$ \\
NOA & $0.147^{*}$ & $(1.67)$ & -0.045 & $(-0.50)$ \\
MKTSHARE & $-0.426^{* *}$ & $(-2.12)$ & $-0.513^{* *}$ & $(-2.10)$ \\
INST & -0.017 & $(-0.28)$ & 0.068 & $(0.90)$ \\
\%CL & 0.337 & $(1.42)$ & $0.817 * * *$ & $(3.26)$ \\
ZSCORE & -0.013 & $(-1.28)$ & $-0.032^{* *}$ & $(-2.40)$ \\
MANUF & 0.080 & $(1.17)$ & 0.115 & $(1.54)$ \\
AUDTEN & $-0.015^{* *}$ & $(-2.36)$ & $-0.014 *$ & $(-1.77)$ \\
CYCLE & 0.000 & $(0.06)$ & 0.001 & $(1.24)$ \\
MTR & -0.024 & $(-0.19)$ & 0.015 & $(0.09)$ \\
ACCR & $1.744 * * *$ & $(2.80)$ & & \\
YEAR & YES & & YES & \\
DUMMIES & & & & \\
(Intercept) & -0.276 & $(-1.07)$ & -0.461 & $(-1.52)$ \\
\hline N & 137 & & 137 & \\
adj. R2 & 0.233 & & 0.146 & \\
\hline
\end{tabular}

$\mathrm{t}$ statistics in parentheses

Significance is indicated by $* p \leq 0.10, * * p \leq 0.05, * * * p \leq 0.01$, based on firm-level clustered errors 
Table 7 Regression Analysis of Earnings Management: Pre versus Post Implementation for Implementers and Control Sample

\begin{tabular}{|c|c|c|c|c|c|c|c|c|}
\hline & \multicolumn{2}{|l|}{ ABSDA } & \multicolumn{2}{|l|}{ REMDISC } & \multicolumn{2}{|l|}{ REMPROD } & \multicolumn{2}{|l|}{ REMCASH } \\
\hline & Coeff. & t-value & Coeff. & t-value & Coeff. & t-value & Coeff. & t-value \\
\hline ERP & -0.011 & $(-1.05)$ & 0.014 & $(0.95)$ & 0.000 & $(0.03)$ & 0.000 & $(0.02)$ \\
\hline POST & -0.012 & $(-0.86)$ & -0.006 & $(-0.32)$ & -0.023 & $(-1.37)$ & -0.012 & $(-0.93)$ \\
\hline ERP $\times$ POST & -0.002 & $(-0.12)$ & $-0.051^{* *}$ & $(-2.02)$ & -0.034 & $(-1.56)$ & 0.006 & $(0.35)$ \\
\hline LGTA & $-0.007 * * *$ & $(-3.35)$ & $0.042 * * *$ & $(6.22)$ & 0.006 & $(1.04)$ & -0.004 & $(-0.71)$ \\
\hline ROA & $-0.166^{* *}$ & $(-2.50)$ & 0.028 & $(0.48)$ & $-0.287 * * *$ & $(-4.37)$ & $-0.316 * * *$ & $(-3.78)$ \\
\hline AUD & 0.003 & $(0.43)$ & 0.003 & $(0.19)$ & $0.025 *$ & $(1.71)$ & 0.006 & $(0.69)$ \\
\hline MTB & 0.003 & $(1.60)$ & $-0.010 * * *$ & $(-2.69)$ & $-0.008 * *$ & $(-2.25)$ & -0.003 & $(-1.20)$ \\
\hline LEV & -0.013 & $(-0.50)$ & -0.042 & $(-1.00)$ & -0.008 & $(-0.18)$ & -0.017 & $(-0.51)$ \\
\hline NOA & -0.003 & $(-0.29)$ & 0.006 & $(0.27)$ & 0.011 & $(0.63)$ & $-0.032 * * *$ & $(-2.72)$ \\
\hline MKTSHARE & -0.013 & $(-0.74)$ & -0.035 & $(-1.11)$ & -0.028 & $(-0.84)$ & $0.057 * * *$ & $(2.71)$ \\
\hline INST & -0.001 & $(-0.34)$ & $0.014^{*}$ & $(1.70)$ & 0.003 & $(0.45)$ & $-0.007 *$ & $(-1.84)$ \\
\hline$\% \mathrm{CL}$ & $0.112 * *$ & $(2.25)$ & $-0.368 * * *$ & $(-4.89)$ & $0.266^{* * *}$ & $(4.01)$ & -0.069 & $(-0.92)$ \\
\hline ZSCORE & 0.000 & $(0.06)$ & $-0.005^{* * *}$ & $(-2.85)$ & $-0.004 * *$ & $(-2.34)$ & -0.001 & $(-1.07)$ \\
\hline MANUF & -0.005 & $(-0.54)$ & 0.013 & $(0.96)$ & 0.013 & $(0.96)$ & -0.007 & $(-0.77)$ \\
\hline AUDTEN & -0.000 & $(-0.10)$ & -0.001 & $(-0.90)$ & $-0.002 * *$ & $(-2.10)$ & $-0.001 *$ & $(-1.78)$ \\
\hline CYCLE & -0.000 & $(-1.59)$ & $-0.000 * *$ & $(-2.11)$ & $-0.000 *$ & $(-1.77)$ & $0.000 * *$ & $(2.56)$ \\
\hline MTR & -0.005 & $(-0.24)$ & -0.042 & $(-1.19)$ & $-0.071 * *$ & $(-2.10)$ & $-0.091 * * *$ & $(-3.49)$ \\
\hline ACCR & & & $0.218 * * *$ & $(3.83)$ & $0.133 * * *$ & $(2.58)$ & & \\
\hline YEAR & YES & & YES & & YES & & YES & \\
\hline $\begin{array}{l}\text { DUMMIES } \\
\text { (Intercept) }\end{array}$ & $0.125 * *$ & $(2.21)$ & 0.078 & $(1.09)$ & -0.038 & $(-0.79)$ & -0.038 & $(-0.55)$ \\
\hline $\mathrm{N}$ & 1308 & & 1308 & & 1308 & & 1308 & \\
\hline adj. R2 & 0.103 & & 0.209 & & 0.139 & & 0.187 & \\
\hline$F$ test $\beta 1+\beta 3=0$ & -0.013 & 2.27 & $-0.037^{*}$ & 3.21 & $-0.034 * * *$ & 3.92 & 0.006 & 0.19 \\
\hline
\end{tabular}

$\mathrm{t}$ statistics in parentheses Significance is indicated by $* p \leq 0.10, * * p \leq 0.05, * * * p \leq 0.01$, based on firm-level clustered errors 
Table 7 Continued

\begin{tabular}{lllll}
\hline & REM1 & \multicolumn{3}{l}{ REM2 } \\
& Coeff. & t-value & Coeff. & t-value \\
\hline ERP & 0.015 & $(0.59)$ & 0.014 & $(0.49)$ \\
POST & -0.029 & $(-0.90)$ & -0.043 & $(-1.16)$ \\
ERP x POST & $-0.085^{* *}$ & $(-1.99)$ & -0.077 & $(-1.54)$ \\
LGTA & $0.048^{* * *}$ & $(4.26)$ & $0.043 * * *$ & $(3.02)$ \\
ROA & $-0.258^{* *}$ & $(-2.41)$ & $-0.476^{* * *}$ & $(-2.81)$ \\
AUD & 0.028 & $(1.04)$ & 0.032 & $(1.02)$ \\
MTB & $-0.018^{* * *}$ & $(-2.60)$ & $-0.021^{* * *}$ & $(-2.58)$ \\
LEV & -0.050 & $(-0.66)$ & -0.099 & $(-1.06)$ \\
NOA & 0.017 & $(0.49)$ & -0.021 & $(-0.54)$ \\
MKTSHARE & -0.063 & $(-1.18)$ & 0.013 & $(0.21)$ \\
INST & 0.017 & $(1.22)$ & 0.008 & $(0.55)$ \\
\%CL & -0.101 & $(-0.80)$ & -0.193 & $(-1.17)$ \\
ZSCORE & $-0.009 * * *$ & $(-2.87)$ & $-0.011 * * *$ & $(-3.04)$ \\
MANUF & 0.026 & $(1.09)$ & 0.013 & $(0.45)$ \\
AUDTEN & $-0.003 *$ & $(-1.69)$ & $-0.004 *$ & $(-1.86)$ \\
CYCLE & $-0.000^{* *}$ & $(-2.22)$ & -0.000 & $(-0.65)$ \\
MTR & $-0.114^{*}$ & $(-1.77)$ & $-0.196 * *$ & $(-2.50)$ \\
ACCR & $0.351 * * *$ & $(3.58)$ & & \\
YEAR & YES & & YES & \\
DUMMIES & & & & \\
(Intercept) & 0.039 & $(0.40)$ & 0.010 & $(0.09)$ \\
\hline N & 1308 & & 1308 & \\
adj. R2 & 0.114 & & 0.102 & \\
\hline F test $\beta 1+\beta 3=0$ & $-0.070^{* * *}$ & 4.03 & -0.063 & 2.36 \\
\hline t statistics in parentheses & & & \\
Significance is indicated by $* p \leq 0.10, * *$ & $p \leq 0.05, * * * p \leq 0.01$, based on firm-level clustered errors \\
& & & &
\end{tabular}


Table 8 Regression Analysis of Earnings Management for Suspect Firms: Pre versus Post Implementation Implementers and Control Sample

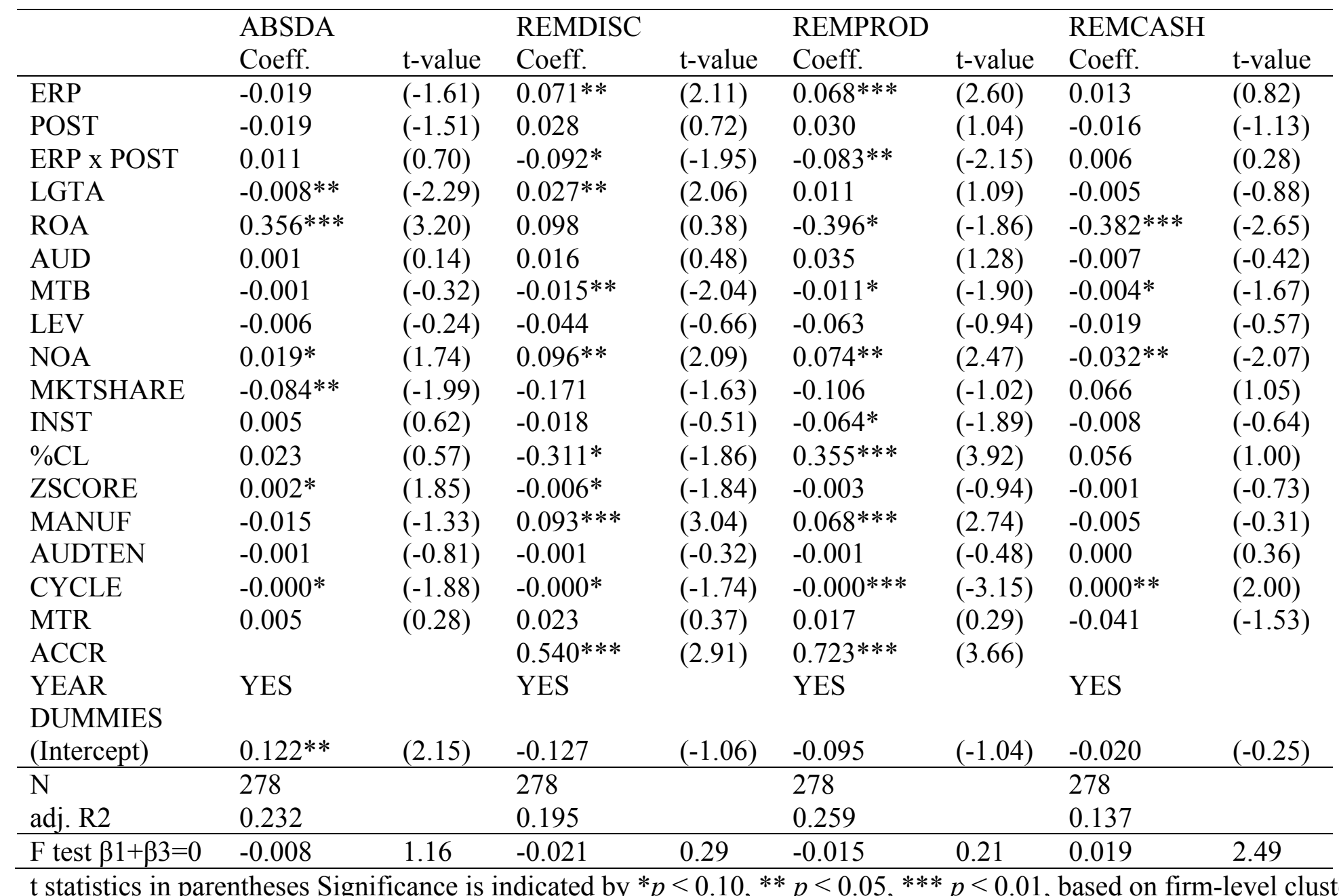

$\mathrm{t}$ statistics in parentheses Significance is indicated by $* p \leq 0.10, * * p \leq 0.05, * * * p \leq 0.01$, based on firm-level clustered errors 
Table 8 Continued

\begin{tabular}{lllll}
\hline & REM1 & \multicolumn{3}{l}{ REM2 } \\
& Coeff. & t-value & Coeff. & t-value \\
\hline ERP & $0.139 * *$ & $(2.52)$ & $0.167 * * *$ & $(2.70)$ \\
POST & 0.058 & $(0.91)$ & 0.022 & $(0.30)$ \\
ERP x POST & $-0.174 * *$ & $(-2.17)$ & $-0.159 *$ & $(-1.76)$ \\
LGTA & $0.038^{*}$ & $(1.74)$ & 0.028 & $(1.13)$ \\
ROA & -0.298 & $(-0.68)$ & -0.634 & $(-1.20)$ \\
AUD & 0.052 & $(0.91)$ & 0.032 & $(0.46)$ \\
MTB & $-0.026 * *$ & $(-2.07)$ & $-0.032 * *$ & $(-2.20)$ \\
LEV & -0.107 & $(-0.86)$ & -0.157 & $(-1.08)$ \\
NOA & $0.170 * *$ & $(2.38)$ & 0.098 & $(1.22)$ \\
MKTSHARE & -0.277 & $(-1.43)$ & -0.110 & $(-0.42)$ \\
INST & -0.082 & $(-1.26)$ & -0.106 & $(-1.40)$ \\
\%CL & 0.044 & $(0.18)$ & 0.102 & $(0.35)$ \\
ZSCORE & -0.009 & $(-1.44)$ & -0.012 & $(-1.54)$ \\
MANUF & $0.161 * * *$ & $(3.18)$ & $0.146 * *$ & $(2.52)$ \\
AUDTEN & -0.002 & $(-0.44)$ & -0.001 & $(-0.19)$ \\
CYCLE & $-0.001 * *$ & $(-2.57)$ & -0.000 & $(-1.07)$ \\
MTR & 0.040 & $(0.35)$ & -0.035 & $(-0.24)$ \\
ACCR & $1.263 * * *$ & $(3.72)$ & & \\
YEAR & YES & & YES & \\
DUMMIES & & & & \\
(Intercept) & -0.222 & $(-1.17)$ & -0.269 & $(-0.98)$ \\
\hline N & 278 & & 278 & \\
adj. R2 & 0.173 & & 0.084 & \\
\hline F Test $\beta 1+\beta 3=0$ & -0.035 & 0.27 & 0.008 & 0.01 \\
\hline t statistics in parentheses & & & \\
Significance is indicated by $* p \leq 0.10, * *$ & $p \leq 0.05, * * * p \leq 0.01$, based on firm-level clustered errors
\end{tabular}


Table 9 Efficient Model Analysis of Earnings Management: Pre versus Post Implementation - Implementers and Control Sample

\begin{tabular}{|c|c|c|c|c|c|c|c|c|c|c|c|c|}
\hline & ABSDA & & REM & & REM & & REM & & REM1 & & REM2 & \\
\hline & Coeff. & t-value & $\begin{array}{l}\text { DIS } \\
\text { Coeff. }\end{array}$ & t-value & $\begin{array}{l}\text { PROD } \\
\text { Coeff. }\end{array}$ & t-value & $\begin{array}{l}\text { CASH } \\
\text { Coeff. }\end{array}$ & t-value & Coeff. & t-value & Coeff. & \\
\hline ERP & -0.010 & $(-0.90)$ & 0.009 & $(0.60)$ & 0.002 & $(0.17)$ & 0.005 & $(0.48)$ & 0.011 & $(0.47)$ & 0.016 & $(0.56)$ \\
\hline POST & -0.010 & $(-0.69)$ & -0.010 & $(-0.50)$ & -0.020 & $(-1.19)$ & -0.004 & $(-0.31)$ & -0.030 & $(-0.95)$ & -0.034 & $(-0.92)$ \\
\hline $\begin{array}{l}\text { ERP x } \\
\text { POST }\end{array}$ & -0.004 & $(-0.29)$ & $-0.046^{*}$ & $(-1.78)$ & -0.035 & $(-1.56)$ & 0.000 & $(0.02)$ & $-0.081 *$ & $(-1.86)$ & -0.081 & $(-1.55)$ \\
\hline LGTA & $-0.013 * * *$ & $(-5.23)$ & $0.042 * * *$ & $(7.00)$ & -0.003 & $(-0.59)$ & $-0.014 * *$ & $(-2.34)$ & $0.039 * * *$ & $(4.05)$ & $0.026 * *$ & (1.97) \\
\hline NOA & -0.004 & $(-0.46)$ & 0.004 & $(0.19)$ & 0.003 & $(0.16)$ & $-0.04 * * *$ & $(-3.36)$ & 0.007 & $(0.20)$ & -0.031 & $(-0.83)$ \\
\hline INST & -0.003 & $(-1.19)$ & 0.011 & $(1.31)$ & -0.004 & $(-0.54)$ & $-0.01 * * *$ & $(-3.58)$ & 0.007 & $(0.48)$ & -0.006 & $(-0.38)$ \\
\hline$\% \mathrm{CL}$ & $0.110 *$ & $(1.86)$ & $-0.38 * * *$ & $(-4.84)$ & $0.289 * * *$ & $(4.43)$ & -0.048 & $(-0.58)$ & -0.092 & $(-0.73)$ & -0.140 & $(-0.84)$ \\
\hline MANU & -0.001 & $(-0.17)$ & 0.010 & $(0.78)$ & 0.018 & $(1.27)$ & 0.000 & $(0.04)$ & 0.028 & (1.18) & 0.028 & $(1.01)$ \\
\hline CYCLE & $-0.000 *$ & $(-1.66)$ & $-0.000^{*}$ & $(-1.65)$ & $-0.000^{*}$ & $(-1.85)$ & $0.000 * *$ & $(2.13)$ & $-0.000 * *$ & $(-2.04)$ & -0.000 & $(-0.87)$ \\
\hline YEARS & YES & & YES & & YES & & YES & & YES & & YES & \\
\hline Cons & $0.153 * * *$ & $(3.78)$ & 0.016 & $(0.26)$ & -0.022 & $(-0.36)$ & -0.008 & $(-0.08)$ & -0.006 & $(-0.07)$ & -0.014 & $(-0.10)$ \\
\hline adj. R2 & 0.068 & & 0.183 & & 0.067 & & 0.072 & & 0.075 & & 0.048 & \\
\hline $\begin{array}{l}\mathrm{F} \text { Test } \\
\beta 1+\beta 3= \\
0\end{array}$ & -0.014 & 2.76 & $-0.037 *$ & 3.17 & $-0.001 * *$ & 4.27 & -0.009 & 0.13 & $-0.070 * *$ & 3.83 & -0.065 & 2.30 \\
\hline
\end{tabular}

t statistics in parentheses

Significance is indicated by $* p \leq 0.10, * * p \leq 0.05, * * * p \leq 0.01$, based on firm-level clustered errors 
Table 10 Efficient Model Regression Analysis of Earnings Management for Suspect Firms: Pre versus Post Implementation - Implementers and Control Sample

\begin{tabular}{|c|c|c|c|c|c|c|c|c|c|c|c|c|}
\hline & ABSDA & & REM & & REM & & REM & & REM1 & & REM2 & \\
\hline & Coeff. & t-value & $\begin{array}{l}\text { DIS } \\
\text { Coeff. }\end{array}$ & t-value & $\begin{array}{l}\text { PROD } \\
\text { Coeff. }\end{array}$ & t-value & $\begin{array}{l}\text { CASH } \\
\text { Coeff. }\end{array}$ & t-value & Coeff. & t-value & Coeff. & t-value \\
\hline ERP & -0.021 & $(-1.54)$ & $0.079 * *$ & $(2.34)$ & $0.073 * * *$ & $(2.73)$ & 0.014 & $(0.87)$ & $0.152 * * *$ & $(2.71)$ & $0.166^{* * *}$ & $(2.66)$ \\
\hline POST & $-0.022 *$ & $(-1.68)$ & 0.015 & $(0.40)$ & 0.021 & $(0.70)$ & -0.010 & $(-0.67)$ & 0.036 & $(0.57)$ & 0.026 & (0.39) \\
\hline $\begin{array}{l}\text { ERP x } \\
\text { POST }\end{array}$ & 0.006 & $(0.37)$ & $-0.085 *$ & $(-1.80)$ & $-0.069 *$ & $(-1.69)$ & 0.006 & $(0.30)$ & $-0.154^{*}$ & $(-1.86)$ & -0.148 & $(-1.65)$ \\
\hline LGTA & $-0.01 * * *$ & $(-3.96)$ & $0.023 *$ & $(1.85)$ & 0.009 & (0.99) & -0.000 & $(-0.02)$ & 0.032 & (1.57) & 0.032 & $(1.43)$ \\
\hline МТВ & $0.004 *$ & $(1.66)$ & $-0.02 * * *$ & $(-3.07)$ & $-0.02 * * *$ & $(-2.68)$ & $-0.01 * * *$ & $(-2.67)$ & $-0.04 * * *$ & $(-3.05)$ & $-0.04 * * *$ & $(-3.14)$ \\
\hline NOA & $0.030 * * *$ & (3.19) & $0.094 * *$ & $(2.22)$ & $0.051 *$ & $(1.86)$ & $-0.04 * * *$ & $(-3.34)$ & $0.145 * *$ & $(2.18)$ & 0.102 & $(1.41)$ \\
\hline INST & 0.004 & $(0.55)$ & -0.041 & $(-1.19)$ & $-0.076 * *$ & $(-2.19)$ & -0.005 & $(-0.47)$ & $-0.118^{*}$ & $(-1.77)$ & $-0.123 *$ & $(-1.71)$ \\
\hline$\% \mathrm{CL}$ & -0.009 & $(-0.24)$ & $-0.326^{*}$ & $(-1.87)$ & $0.349 * * *$ & $(3.67)$ & 0.073 & $(1.36)$ & 0.023 & $(0.09)$ & 0.096 & $(0.34)$ \\
\hline MANU & -0.011 & $(-0.94)$ & $0.092 * * *$ & (3.11) & $0.066 * * *$ & $(2.77)$ & -0.006 & $(-0.42)$ & $0.158 * * *$ & $(3.21)$ & $0.151 * * *$ & $(2.76)$ \\
\hline CYCLE & -0.000 & $(-1.64)$ & -0.000 & $(-1.42)$ & $-0.000 * *$ & $(-2.26)$ & $0.000 * *$ & (2.19) & $-0.001 *$ & $(-1.91)$ & -0.000 & $(-1.22)$ \\
\hline YEARS & YES & & YES & & YES & & YES & & YES & & YES & \\
\hline Cons & $0.166^{* * *}$ & $(4.09)$ & -0.118 & $(-0.84)$ & $-0.208 * *$ & $(-2.15)$ & -0.019 & $(-0.33)$ & -0.326 & $(-1.44)$ & -0.345 & $(-1.36)$ \\
\hline $\mathrm{N}$ & 278 & & 278 & & 278 & & 278 & & 278 & & 278 & \\
\hline adj. R2 & 0.126 & & 0.165 & & 0.159 & & 0.096 & & 0.105 & & 0.082 & \\
\hline $\begin{array}{l}\text { F Test } \\
\beta 1+\beta 3=0\end{array}$ & $-0.015 * *$ & 3.84 & -0.006 & 0.03 & 0.004 & 0.02 & $0.020 * *$ & 3.07 & -0.002 & 0.00 & 0.018 & 0.06 \\
\hline
\end{tabular}

$\mathrm{t}$ statistics in parentheses

Significance is indicated by $* p \leq 0.10, * * p \leq 0.05, * * * p \leq 0.01$, based on firm-level clustered errors 


\section{ESSAY 2: REAL EARNINGS MANAGEMENT AND AUDIT REPORT LAG}

\section{Motivation}

This study examines whether there is a relationship between real earnings management [REM] activities and audit report lags [ARLs]. Following the passage of the Sarbanes-Oley Act [SOX], new SEC rules have reduced the time for 10-K filings as part of the effort to provide timely information to investors and to promote confidence in the capital markets. As a consequence audit report lags became an important concern for regulators.

Prior research defines the audit report lag as the time between the fiscal year end and the date of the audit report. This measure intrinsically reflects auditor effort. More specifically, Bamber et al. (1993) show that audit report lags are a function of the audit work, which in turn is related to the audit's complexity and the auditor's business risk. Consistent with this result, Knechel and Payne (2001) find that audit report lags are positively associated with audit hours, Lobo and Zhao (2013) find a negative relation between audit effort and restatements and Schelleman and Knechel (2010) find that auditors engage in more work when they detect earnings management through accruals.

PCAOB AU Section 329A Substantive Analytical Procedures calls on auditors to consider unexplained differences that may indicate an increased risk of material misstatement. O'Keefe, Simunic and Stein (1994) find that increases in risk exacerbate the scope of the audit plan, resulting in more audit hours being assigned. Thus the presence of abnormal differences that result from REM may increase audit risk and require more audit work to be performed. Specially, I argue that REM activities increase the audit work measured through audit report lags because the unusual or unexpected 
relationships detected in the financial accounts will motivate auditors to perform additional analytical procedures.

Following the passage of SOX, auditing practice changed. Cohen, Dey and Lys (2008) show that while SOX reduced manager's flexibility to engage in accruals management, it was also associated with an increase in the use of REM. This phenomenon was also documented in Graham, Harvey and Rajgopal's (2005) survey were manager's noted a preference for the use of real earnings management - even though it could have a negative impact on their firm's financial condition.

The negative long-term consequences of REM have been broadly explored in prior studies, and the literature conjectures that managing earnings through REM has an adverse impact on future cash flows (Roychowdhury 2006; Badertscher 2011; Cohen and Zarowin 2010). Such declines in client firms' financial condition is thus of interest to auditors, because the financial condition of client-firms is a primary factor influencing auditors' determinants of risk in planning the audit (Pratt and Stice 1994).

Research on the association between REM and audit-related topics is limited. Previous studies have found, however, that auditors care about REM (Zang 2012; Chi, Lisic and Pevzner 2011; Kim and Park 2014; Commerford, Hermanson, Houston and Peters 2014). According to Kim and Park (2014) the presence of real earnings management is a subject of auditor concern because it can contribute to an increase in audit risk. When associated with meeting earnings targets, this increased risk is also associated with auditor resignations. Furthermore, Chi, Lisic and Pevzner (2011) find (consistent with prior literature) that firms audited by higher quality auditors lead managers to use real earnings management, and Järvinen and Myllymäki (2015) 
document that managers of companies that disclose material internal control weaknesses may engage in REM to boost earnings and thus reduce the negative impact of disclosing those material weaknesses.

Using U.S. firm data from 2004 to 2014, I examine the association of REM with audit report lags. I perform my analysis using Roychowdhury's (2006) measures of REM (abnormal operating cash flows, abnormal discretionary expenses and abnormal production). In addition, I focus on firm-years where firms' just meet/beat zero earnings and or the previous year's earnings, and on accelerated versus non-accelerated fillers. My results suggest that after controlling for other factors, auditors perceive firms that engage in real earnings management activities as being more risky - a situation that requires additional audit effort.

This study contributes to the existing literature by extending the literature linking REM to audit practice. Previous studies document that audit effort reduces managers' use of accruals to manage earnings (Caramanis and Lennox 2008), and although REM is not considered a violation of US GAAP, auditors should consider the impact of such practices when performing their risk assessment. To this end, I examine the impact of REM on audit effort as measured by ARLs. Consistent with prior research (Mitra, Song and Yang 2015; Wang and Zhou 2012), my results support the top-down risk-based audit approach required by Auditing Standard No. 5 [PCAOB, 2007], in that the presence of earnings management, even when it violates no rules per se, invokes greater scrutiny and additional audit effort. 


\section{Prior Literature}

Prior research documents that managers engage in earnings management to meet earnings benchmarks and to avoid (or minimize) losses (Burgstahler and Dichev 1997; Gunny 2010). The literature suggests that managers are willing to engage in this behavior because the capital markets reward those firms that meet or beat earnings thresholds (Barth, Elliott and Finn 1999; Bartov, Givoly and Hayn 2002; Lopez and Rees 2002).

Most of the prior studies on earnings management have focused on managers' use of discretionary accruals to meet these targets. However, several studies have also studied REM as a form of earnings management. While not a new concept, REM is defined as the departure from normal operations by managers in order to mislead shareholders to make them believe a target has been met (Roychowdhury 2006). Graham et al.'s (2005) seminal paper reveals that managers are willing to take these kinds of actions, even if they are a detriment to future firm value, because REM activities are harder to detect.

As described above earnings management can be achieved by taking advantage of accounting discretion or by changing the timing or structure of real transactions (Bartov 1991; Ewert and Wagenhofer 2005). A unique characteristic of this latter approach is that it results in a reduction in long-term firm value (Ewert and Wagenhofer 2005; Roychowdhury 2006; and Zang 2012), while accruals management is not likely to destroy long-term value (Badertscher 2011). Earnings management choices depend, however, on managers' flexibility to make those choices. After the passage of SOX, earnings management through accruals became more likely to draw scrutiny from auditors and regulators (Cohen et al. 2008), and, as shown by Ewert and Wagenhofer (2005), in a rational expectations equilibrium model, regulations that are intended to 
improve earnings quality can actually lead to a substitution effect between accruals management and REM. The result is that regulatory actions that restrict managers' ability to use accruals management can increase REM and decrease firm value.

Cohen et al. (2008) document that after the passage of SOX, the prevalence of accruals management declined while the prevalence of REM increased. They attribute this phenomenon to accruals management being more likely to draw the attention of auditors and regulators. This substitution effect is also studied by Zang (2007) who documents a trade-off between accruals management and REM based on the relative costliness of the two mechanisms.

The general concensus among REM studies is that real activities actions negatively affect the future performance of firms engaged in these practices (Cohen and Zarowin 2010; Roychowdhury 2006; Burgstahler 2011). Cohen and Zarowin (2010) find, for example, that firms that engage in real activities management prior to a seasoned equity offering, subsequently experience a decline in performance. Consistent with this finding, Roychowdhury (2006) conjectures that real activities manipulations can diminish firm value, since these practices have a negative effect on the future cash flows. In addition, Kim and Sohn (2013) show that REM is costly because the capital markets detect the adverse future consequences of REM which in turn leads to an increase in the cost of capital. ${ }^{1}$ Such managerial opportunism should not only cause investors to scrutinize the abnormal differences, auditors should as well, since clients' abnormally aggressive operating decisions may affect the client's business risk.

${ }^{1}$ Uniquely, Gunny (2010) finds a positive association between REM and one-year-ahead ROA. 
Broadly speaking, client business risk is defined as the risk that the client's economic condition will deteriroate in the short or long term (Johnstone 2000). As client business risk increases, the potential for economic deterioration also heightens earnings manipulation risk (Burgstahler and Dichev 1997), and manipulation risk is associated with audit risk (Bedard and Johnstone 2004). Additional research also argues that the client's financial condition can influence the level of audit risk (Johnstone 2000; O'Keefe et al. 1994). It follows, therefore, that real activities actions are directly linked to audit risk and business risk. For example, a firm cutting advertising expense to achieve a short term earnings target is also likely to experience a reduction in future cash flows that otherwise would have derived from that advertising. Similarly, reductions in SG\&A might adversely affect the effectiveness of firms' internal control systems. Each of these impacts the business/audit risk and increases the auditor's litigation risk. Pratt and Stice (1992) find that auditors are concerned about clients' financial condition because "poor financial condition [is] associated with higher levels of litigation risk and more audit evidence" (p.640). Consistent with this statement, Bamber et al. (1993) find that audit report lags, a measure of audit effort, are associated with clients' financial condition. Since audit report lags can be a proxy for audit effort - the unusual increased hours spent on audit planning, substantive testing and internal control evaluation (Knechel, Rouse and Schelleman 2009) they also reveal what Blankley, Hurtt and MacGregor (2015) implicitly describe as difficulties faced during the audit.

Accounting researchers have used audit report lags as a proxy for audit effort (Knechel et al., 2009) and for the amount of audit work required (Knechel, et al. 2001; Tanyi, Raghunandan and Barua 2010; Knechel and Sharma 2012). This proxy is 
important because it can affect earnings announcements and is also considered the most important factor in the timeliness of earnings announcements (Ashton, Willingham and Elliot 1987). Givoly and Palmon (1982) find, for example, that markets react negatively to longer audit report lags. They explain this reaction as representative of a loss of information content.

Since prior research provides evidence that earnings management is associated with audit litigation risk (Heninger 2001; Bedard and Johnstone 2004; Lee and Son 2009), and Caramanis and Lennox (2008) show that low levels of audit hours are associated with more accruals management to meet or beat benchmarks, auditors are likely to take measures to mitigate this risk by applying more audit effort. Bedard and Johnston (2004) suggest, for example, that auditors mitigate their exposure risk by charging higher audit fees to cover the cost associated with spending more time on risky audits, and Lee and Son (2009) document that earnings management is reduced when auditors increase effort. These studies, however, explore only the association of audit effort with abnormal accruals. This is understandable, because accruals management may involve a violation of GAAP while REM does not. Recent studies show, however, that auditors do care about REM (Zang 2012; Chi, Lisic and Pevzner 2011; Kim and Park 2014). I extend those studies by examining whether the increased risk caused by REM is a trigger for greater scrutiny by auditors. Given these arguments I express my hypothesis about the effect of REM on audit report lags in the following null form:

H1: There is no association between REM and audit report lags.

Then SEC Chairman, Arthur Levitt noted in 1998 that markets punish companies that miss earnings benchmarks. Companies, therefore, have incentives to meet or beat 
those earnings benchmarks in order to avoid the negative impact that failing to meet benchmarks would have on stock values. This phenomenon has been studied by prior studies (Degeorge, Patel and Zeckhauser 1999; Bartov et al. 2002; Brown and Caylor 2005). Kasznik and McNichols (2002) find, for example, that investors perceive firms that consistently meet thresholds as being less risky and Rickling, Rama and Raghunandan (2013) find that the relevance of earnings thresholds is also recognized by auditors. They show that firms that repeatedly meet or beat analyst expectations are viewed as less risky, since audit fees are negatively associated with meet/beat earnings thresholds. It would seem, therefore, that while meeting benchmarks is indicative of lower risk (shorter ARLs), meeting them in concert with REM would result in increased audit effort (longer ARLs). To test which factor dominates this relationship I examine the association of REM with ARLs for subsamples of firms that meet/beat (do not meet/beat) earnings benchmarks. My second hypothesis (in null form) is thus:

H2: Meeting or beating earnings benchmarks via REM is not associated with audit report lags.

The SEC has introduced important changes that have affected the audit environment. Specially, the SEC has shortened the filing deadlines for certain firms, with the intent to provide timely information to investors. In particular the changed rules establish three categories of issuers "large accelerated filers," "accelerated filers," and “non-accelerated filers" (17 CFR 240.12b-2 - Definitions). Large accelerated filers must generally file their Form 10-K within 60 days of the firm's fiscal year end. Accelerated filers are required to file their $10-\mathrm{K}$ within 75 days of fiscal year end. Non-accelerated filers must file their 10-K within 90 days of their fiscal year end. As discussed by Munsif, 
Raghunandan and Rama (2012), the differences in the deadlines for accelerated filers and non-accelerated filers, has an impact on audit effort. In particular they note that nonaccelerated filers are not required to have auditor attestation on internal controls while accelerated filers are subject to auditor and manager assessment of internal controls. If, as a consequence, non-accelerated filers are riskier, REM should be associated with longer ARLs to a greater extent for non-accelerated than for accelerated filers. If, however, accelerated filers, by virtue of their size, represent higher business risk for auditors, then REM would be with associated with longer ARLs to a greater extent for accelerated than for non-accelerated filers. Given these contradictory possibilities, my third hypothesis (in null form) is:

H3: REM is not associated with audit report lags differentially by filing status.

\section{Research Method}

To measure real earnings management, I rely on the three proxies of Roychowdhury (2006): abnormal cash flow from operations, abnormal discretionary expenses, and abnormal production costs. Companies may, for example, boost their sales by offering temporary discounts and lenient credit terms to customers. Managers may, similarly, boost earnings by cutting discretionary operating expenses, or they may overproduce to shift manufacturing overhead to the balance sheet. To measure these three factors, it is necessary to generate the normal levels of: cash flow from operations [CO], discretionary expenses [DX], and production costs [PC].

The residuals from the following models serve as the measures of abnormal cash from operations [REMCASH], discretionary expenses [REMDISC] and production costs [REMPROD]. Following Cohen and Zarowin (2010) and Cohen, Dey and Lys (2008), I 
also create a composite measure REM1 which is the sum of components REMDISC and REMPROD, and REM2 which is which is the sum of components REMDISC, REMPROD and REMCASH. To obtain the residuals, I run the following cross sectional regressions for each real earnings management activity. I estimate equations 1 to 3 by year and two-digit SIC code. ${ }^{2}$

Operating cash flows:

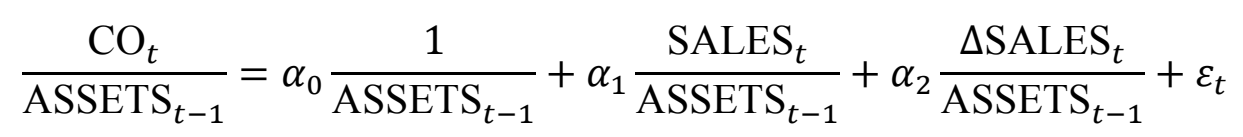

Where:

$$
\begin{array}{ll}
\mathrm{CO} & =\text { cash flow from operations } \\
\text { ASSETS } & =\text { total assets } \\
\text { SALES } & =\text { net sales } \\
\triangle \mathrm{SALES} & =\text { change in sales from time } \mathrm{t}-1 \text { to } \mathrm{t}
\end{array}
$$

Discretionary expenses:

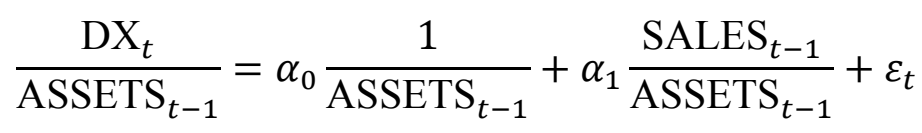

Where:

$$
\mathrm{DX}=\text { discretionary expense measured as the sum of advertising expense, }
$$
$\mathrm{R} \& \mathrm{D}$, and selling, general, and administrative expenses and the other variables are as defined above.

Production costs:

\footnotetext{
${ }^{2}$ I require a minimum of 15 observation for each two-digit SIC code in each year to make these estimations.
} 


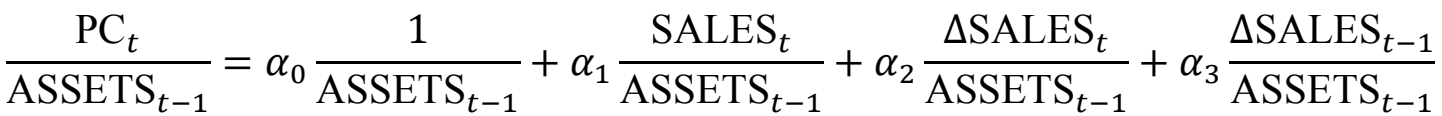

$$
\begin{aligned}
& +\varepsilon_{t}
\end{aligned}
$$

Where:

$\mathrm{PC}=$ the sum of the cost of goods sold and change in inventory.

Consistent with prior studies I multiply REMDISC and REMCASH by negative 1, so that they can be interpreted in the same way as REMPROD.

In order to examine the association between real earnings management and audit report lags I follow prior studies (Krishnan and Yang 2009; Tanyi et al. 2010; Knechel and Sharma 2012; Munsif et al. 2012; Blankley, Hurtt and MacGregor 2014), in constructing my model. I include five variables to control for the potential effect of different financial risks on audit delay. I include the presence of losses [LOSS], the current ratio $[\mathrm{CR}]$, return on assets [ROA], leverage [LEV], and going concern opinions [GC]. To control for differences across industry groups, I incorporate 3 dichotomous variables for high litigation industries [HIGHTLIT], high growth industries [HIGHGROWTH] and high tech industries [HIGHTECH]. Furthermore I include six variables that are proxies for audit complexity. These are busy season [BUSY], total assets [LGTA], business segments [LGSEGMENTS], foreign operations [FOROPS], extraordinary items [EXITEM], and pension plans [PENSION]. Finally, I include a number of variables that have been identified in prior literature as important determinants of audit report lags. These are auditor size [BIG4], auditor changes [AUCHG], audit fees [LGAUDITFEE], and earnings growth [EARGROWTH]. I include discretionary accruals 
[ABSDACC] because prior research has shown earnings management through accruals to be a substitute for or complement to REM. The resulting empirical model is:

$$
\begin{aligned}
\mathrm{LAG}= & \beta_{0}+\beta_{1} \mathrm{REM}+\beta_{2} \mathrm{LGTA}+\beta_{3} \mathrm{LGSEGMENTS}+\beta_{4} \mathrm{LGSEGMENTS}+ \\
& \beta_{5} \mathrm{LGAUDITFEE}+\beta_{6} \mathrm{CR}+\beta_{7} \mathrm{ROA}+\beta_{8} \mathrm{LEV}+\beta_{9} \text { EARGROWTH }+ \\
& \beta_{10} \mathrm{FOROPS}+\beta_{11} \mathrm{PENSION}+\beta_{12} \mathrm{GC}+\beta_{13} \mathrm{LOSS}+\beta_{14} \text { EXITEM }+ \\
& \beta_{15} \mathrm{ACQ}+\beta_{16} \mathrm{BIG} 4+\beta_{17} \mathrm{AUCHG}+\beta_{18} \mathrm{HIGHTECH}+\beta_{19} \mathrm{HIGHGROWTH}+ \\
& \beta_{20} \mathrm{HIGHTECH}+\beta_{21} \mathrm{BUSY}+\beta_{22} \mathrm{ABSDACC}+\varepsilon \\
& \text { Where: }
\end{aligned}
$$

LAG $=$ logarithm of audit report lags;

LGTA $=$ logarithm of total assets (\$ millions);

LGSEGMENTS= logarithm of the number of business segments;

LGAUDITFEE = logarithm of audit fees ( $\$$ thousands);

$\mathrm{CR}=$ current ratio;

ROA = earnings before interest and taxes;

LEV $=$ long-term debt divided by total assets;

EARGROWTH= the change in net income divided by lagged net income;

FOROPS $=1$ if the firm has any foreign operations, 0 otherwise;

PENSION $=1$ if the firm has a defined benefit pension plan, 0 otherwise;

$\mathrm{GC}=1$ if the auditor issued a going-concern opinion, 0 otherwise;

LOSS $=1$ if the firm reported a loss, 0 otherwise;

EXITEM= 1 if the client reported an extraordinary item, 0 otherwise;

$\mathrm{ACQ}=1$ if the firm engaged in an acquisition or merger, 0 otherwise;

$\mathrm{BIG} 4=1$ if the firm is audited by a BIG 4 auditor, 0 otherwise; 
$\mathrm{AUCHG}=1$ if the firm changed auditor during the current year, 0 otherwise;

HIGHTECH= 1 if the firm is in high-tech industry (SIC codes 283,284 , $357,366,367,371,382,384$, or 737), 0 otherwise;

HIGHGROWTH= 1 if the firm is in a high-growth industry (SIC codes $35,45,48,49,52,57,73,78$ or 80$), 0$ otherwise;

HIGHTLIT $=1$ if the firm is in a high litigation industry (SIC codes 28,35 , $36,38,73), 0$ otherwise;

BUSY $=1$ if the firm's fiscal year ends in December or January, 0 otherwise;

ABSDACC $=$ Absolute value of discretionary accruals estimated using performance-adjusted cross-sectional modified Jones.

To test hypotheses 2 and 3 I use the same model I employ to test hypothesis 1, but partition the sample to: 1) focus on firms-years that just meet/beat earnings targets, and 2) separate accelerated from non-accelerated filers.

\section{Sample Selection}

My sample period covers 2004-2014. Table 1, Panel A presents the data selection process. I use the Audit Analytics database to identify the audit report date. Financial data is obtained from the Compustat annual database. I begin with the Audit Analytics data and delete firms that are in the financial and utility sectors. I remove OTC pink sheet firms, ${ }^{3}$ firms missing SIC codes, and duplicate data. Finally, I merge this data with the

\footnotetext{
${ }^{3}$ The filings of OTC-pink sheet firms were excluded from the sample because the companies are unable or unwilling to meet the minimum U.S. stock market
} 
financial data from Compustat and delete firms-years without the data necessary to calculate the REM estimations. My final sample for the audit report lag model contains 36,416 firm year-observations. The number of observations used in each of the regressions is a subgroup of the overall sample because there is variation in the number of observations available for each REM model. I winsorize continuous variables at the $1 \%$ and $99 \%$ levels.

Similar to prior studies I calculate ARLs as the number of days between fiscal year-end and the date of the audit report. Table 1, Panel B presents trends in the ARL for: all firms, accelerated fillers, and non-accelerated filers. The proportions of this sample are distributed by filer status as follows: large accelerated 30\%, accelerated 33\%, and non-accelerated filers $37 \%$.

Consistent with prior research (Krishnan and Yang 2009) there is a decline in the median audit report lag over time. This trend is explained by the recent rule changes which aimed to reduce audit report lags and provide timely information to investors. After 2006 the median audit report lag dropped significantly as a response to these new rules. It is interesting to observe that non-accelerated fillers have the same response to the SEC rules even though they were not required to file within a shorter time period.

\section{Results}

\section{Descriptive Data}

Table 2 provides descriptive statistics for the variables used in the model. Panel A displays the descriptive statistics for the continuous variables. The REM variables

qualifications, and because they are not required to file financial statements with the SEC. 
(REMCASH, REMDISC and REMPROD) are, in general, consistent with prior studies (Cohen et al. 2008, and Zang 2012). The mean (median) of abnormal cash flow from operations (REMCASH) are $0.09(-0.02)$. The mean (median) for the abnormal discretionary expenditures measure (REMDISC) are $-0.08(-0.00)$, and the mean (median) for the abnormal production measure (REMPROD) are $0.01(-0.01)$. The mean (median) of the absolute value of discretionary accruals (ABSDACC) are $0.11(0.10)$, and the mean (median) of audit report lags are 72.6 days (69 days).

The firms cover a wide range of conditions (accelerated filer and non-accelerated filers), and have an average size (LGTA) of 5.53 (median 5.65). The mean current ratio (CR) for these firms is 2.61 and the median is 1.97. In Panel B we can see that approximately $67 \%$ of the firms have a December or January fiscal year end (BUSY). A loss is noted in about $40 \%$ of the firm years and over $49 \%$ of the firms have foreign operations (FOROPS). On average $21 \%$ of the firms are audited by Big 4 audit firms and $6 \%$ of the firms experienced a change in auditor during a given year (AUCHG).

Table 3 reports the Pearson correlations. The analysis shows a significant correlation between REMDISC and REMPROD. This result is consistent with Zang (2012), and indicates that firms use both forms of real earnings management at the same time. Consistent with our first hypothesis, all our REM measures are significantly correlated with audit report lags. The LGTA is also significantly correlated with other variables, indicating some degree of multicollinearity, To ensure that this is not problem, I calculate the variance inflation factor (VIF) for the variables used in the regression model. Untabulated results show that all variables had VIF scores under 5.68 leading me to conclude that multicollinearity is not a problem. 


\section{Results}

H1

Table 4 presents the multivariate tests examining the association of REM with ARLs after controlling for factors associated with audit report lags. The R-squared for REMCASH, REMDISC, REMPROD, REM1 and REM2 are 0.289, 0.287, 0.310, 0.307 and 0.307 respectively, and are consistent with prior research. The magnitude and significance of the control variables are also generally consistent with prior studies. For example, the coefficients of LGTA, LOSS and GC are significant and have the expected sign. The results indicate that large firms have shorter ARLs, and firms in poor financial conditions have longer ARLs.

Regarding my variables of interest, REMDISC is positively associated with audit report lags ( $p$-value $\leq 0.01)$, as are REMPROD $(p \leq 0.01)$, REM1 $(p \leq 0.01)$, and REM2 $(p \leq 0.01)$. The coefficient on REMCASH is, however, not significantly different from zero $(p=0.54)$. The coefficient on REMDISC is associated with a 2 percent increase in audit report lags. The increase in audit report lags is also significant for REMPROD, REM1 and REM2, with incremental increases in ARLs equivalent to 3.26 percent, 2.27 percent and 1.47 percent respectively.

The results presented in Table 4 columns (2)-(5) suggest that consistent with H1, real earnings management activities (REMDISC, REMPROD, REM1 and REM2) are associated with longer audit report lags. This suggests that auditors recognize the risk driven by REM and, as a consequence, increase their audit effort. 


\section{H2}

Prior studies have indicated that firms with earnings just at or above zero are more likely to have engaged in earnings management to meet those benchmarks (Burgstahler and Dichev 1997, Roychowdhury 2006). Following prior studies, I classify firms that manage their earnings upward close to zero [Suspects] as those firms with net income before extraordinary items, scaled by total assets between 0 and 0.01 . This subsample of firms with stronger incentives to manage earnings may be indicative of increased risk and, as a result, auditors may assign significantly more audit hours to these firms. Table 5, Panel A, reports the results of my regressions for the two groups: Suspect and NonSuspect firms. In all of the regressions I find that the coefficients on REMDISC, REMPROD, REM1 and REM2 are positive and highly significant ( $p$-values less than 0.01). This would indicate that the presence of REM results in greater audit effort, regardless of whether firms meet earnings targets.

Table 5, Panel B shows however, that the magnitude of the impact is significantly greater for suspect firms. The coefficients on REMDISC for suspect firms and nonsuspect firms are, for example, 0.058 and 0.017 respectively. These indicate that, on average, the presence of REM along with firms just meeting earnings targets is associated 5.9 percent increase in ARLs, while REM alone increases ARLs 1.7 percent. The magnitude of the coefficient for Suspect firms is 3.4 times that of the coefficient for NonSuspects. With the exception of the coefficients on REMCASH, Wald tests show that the differences between the coefficients for the two sub-samples are statistically significant at the 0.001 level, with the coefficients for the suspect firms being significantly greater than those for non-suspects. This result is consistent with the impact of REM on audit effort 
being more pronounced for the suspect firms, as auditors employ more time in order to reduce the risk associated with the real earnings management activities for these firms.

\section{H3}

Table 6 presents the results of my tests of an association between filing status, REM and ARLs. Panel A of Table 6 shows that REM is associated with audit report lags for both accelerated and non-accelerated filers. These results are consistent with my previous tests in that the coefficients on REMDISC, REMPROD, REM1 and REM2 are positive and significant in all the models. For accelerated fillers the coefficients are: REMDISC (0.0686; $p$-value $\leq 0.01)$, REMPROD $(0.047 ; p \leq 0.01)$, REM1 $(0.035 ; p \leq$ $0.01)$, and REM2 $(0.028 ; p \leq 0.01)$. For non-accelerated filers the coefficients are: REMDISC (0.012; $p$-value $\leq 0.05)$, REMPROD $(0.020 ; p \leq 0.01)$, REM1 $(0.0155 ; p \leq$ $0.01)$, and REM2 $(0.01 ; p \leq 0.01)$. Thus regardless of filing status, REM is associated with auditors devoting additional time to obtain evidence about client firms' financial reports.

The amount of additional time is not, however, equal across filing groups. Panel B of Table 6 shows that audit report lags are associated with REM to a greater extent for firms that are classified as accelerated filers than for non-accelerated filers. This may be because accelerated filers are, de facto, larger than non-accelerated filers, or because accelerated filers present a higher risk profile because they must comply with SOX Section 404(b) while the Dodd-Frank Act exempted smaller firms from the Section 404(b) attestation requirement. 


\section{Additional Analysis}

\section{Suspect Accelerated Filers vs. Suspect Non-Accelerated Filers}

Since engaging in REM and being a suspect firm or an accelerated filer are associated to a significantly greater extent with ARLs than being a non-suspect or nonaccelerated filer, I examine which of these characteristics is dominant.

Table 7, Panel A presents the results of my tests after partitioning my sample into suspect accelerated filers and suspect non-accelerated filers. For both sub-samples the coefficients are positive and significant (except for REMCASH). However, while the coefficients for the suspect accelerated filer sub-sample appear to be larger than those for the suspect non-accelerated group, Wald tests (untabulated) indicate there are no differences between the groups. I conclude from this that auditors are more cautious and engage in more audit effort when firms just meet earnings benchmarks, regardless of filing status.

\section{Short versus Long Audit Report Lags}

Prior research has shown that changes in $10-\mathrm{K}$ filing dates affect the quality of accounting information (Lambert, Jones and Brazel 2011, Bryant-Kutcher, Peng and Weber 2013). Lambert et al. (2011) show that reductions in filing deadlines reduce the auditors' effectiveness in constraining accruals earnings management. Bryant-Kutcher et al. (2011) find that reductions in filing deadlines result in a decrease in accounting information reliability (firms are more likely to restate financial statements after the timeto-file was reduced). To examine this issue, I partition my sample into short ${ }^{4}$ and long

\footnotetext{
${ }^{4}$ Firms with an audit report lag of less than 30 days are coded 1, 0 otherwise (Short Report Lags). For Long Report Lag, large accelerated filers with an audit report lag of 50
} 
audit report lags and test whether REM is similarly associated with ARLs for the two groups. I use the following model to investigate the relation between short and long audit report lags and REM.

$$
\begin{aligned}
\text { REM }= & \beta_{0}+\beta_{1} \text { SHORT }(\text { LONG })+\beta_{2} \text { LGTA }+\beta_{3} \text { LGSEGMENTS }+ \\
& \beta_{4} \text { LGSEGMENTS }+\beta_{5} \text { LGAUDITFEE }+\beta_{6} \mathrm{CR}+\beta_{7} \text { ROA }+ \\
& \beta_{8} \mathrm{LEV}+\beta_{9} \text { EARGROWTH }+\beta_{10} \text { FOROPS }+\beta_{11} \text { PENSION }+ \\
& \beta_{12} \mathrm{GC}+\beta_{13} \mathrm{LOSS}+\beta_{14} \mathrm{EXITEM}+\beta_{15} \mathrm{ACQ}+\beta_{16} \mathrm{BIG} 4+ \\
& \beta_{17} \mathrm{AUCHG}+\beta_{18} \mathrm{HIGHTECH}+\beta_{19} \mathrm{HIGHGROWTH}+\beta_{20} \mathrm{HIGHTECH}+ \\
& \beta_{21} \mathrm{BUSY}+\beta_{22} \mathrm{ABSDACC}+\varepsilon
\end{aligned}
$$

The results of my tests are reported in Table 8 . Short audit report lags are not associated with REM in any of my models. Interestingly, however, firms with longer audit report lags are associated with lower levels of REM. This result is consistent with Lee and Son (2009) where they show that firms are less likely to engage in accruals management as the audit report lag increases.

\section{Summary}

Prior research has generally examined the conjecture that REM is costly in its impact on financial performance. This study contributes to this area of research by examining the impact of REM on audit effort and the timeliness of financial information. I test the association between REM and audit report lags in general, for a sample of suspect versus non-suspect firms, and for accelerated versus non-accelerated filers. My results indicate that the incidence of REM is associated with longer ARLs. I find that

to 60 days, accelerated filers with audit report lags of 65 to 75 days, and non-accelerated filers with audit report lags of 80 to 90 days are coded 1. Other ARLs are coded 0 . 
overall, REM is associated with ARLs, and that the impact of REM on ARLs is greater for suspect firms. These results are significant in that despite the fact that REM violates no accounting principles, it likely triggers higher risk assessments by auditors and a resulting increase in audit effort. In particular, these results suggest that auditors are allocating more resources to audits when they encounter REM. This association is important, in that it appears REM imposes greater costs on auditors. Since prior research indicates that REM has, to a large extent, replaced accruals management as a way for firms to meet earnings benchmarks, these results should be of importance to auditors as they plan and price audits. It should also be of importance to regulators since shorter filing deadlines put greater pressure on auditors and may interfere with their ability to conduct additional substantive tests when they encounter REM.

\section{List of References}

Ashton, R., J. Willingham, and R. Elliot. 1987. An empirical analysis of audit delay. Journal of Accounting Research 25 (2):275-292.

Badertscher, B. 2011. Overvaluation and the choice of alternative earnings management mechanism. The Accounting Review 86 (5): 1491-1518.

Bamber, E. M., L. Bamber, and M. Schoderbek. 1993. Audit structure and other determinants of audit report lag: An empirical analysis. Auditing: A Journal of Practice \& Theory (Spring): 1-23.

Barth, M., J.A. Elliott, and M.W. Finn. 1999. Market rewards associated with patterns of increasing earnings. Journal of Accounting Research 37 (2): 387-413.

Bartov, E. 1993. The Timing of Assets Sales and Earnings Manipulation. The Accounting Review 68(4): 840-855.

., D. Givoly, and C. Hayn. 2002. The rewards to meeting or beating earnings expectations. Journal of Accounting and Economics 33 (2): 173-204.

Bedard, J., and K. Johnstone. 2004. Earnings manipulation risk, corporate governance risk, and auditors' planning and pricing decisions. The Accounting Review 79 (2): 2747-304. 
Blankley, A., D. Hurtt, and J. MacGregor. 2014. The relationship between audit report lags and future restatements. Auditing: A Journal of Practice \& Theory 33 (2): 2757.

. 2015. Are lengthy audit report lags a warning signal? Current Issues in Auditing 9 (2): 19-28.

Brown, L. and M. Caylor. 2005. A temporal analysis of quarterly thresholds: propensities and valuation consequences. The Accounting Review 80 (2): 423-440.

Bryant-Kutcher, L., E. Y. Peng, and D. P. Weber. 2013. Regulating the timing of disclosure: Insights from the acceleration of 10-K filing deadlines. Journal of Accounting and Public Policy 32: 475-494.

Burgstahler, D., and I. Dichev. 1997. Earnings Management to Avoid Earnings Decreases and Losses. Journal of Accounting \& Economics 24: 99-126.

Caramanis, C. and C. Lennox. 2008. Audit effort and earnings management. Journal of Accounting and Economics 45: 116-138.

Chi, W., L. Lisic, and M. Pevzner. 2011. Is enhanced audit quality associated with greater real earnings management? Accounting Horizons 25 (2): 315-335.

Cohen, D., A. Dey, and T. Lys. 2008. Real and accrual-based earnings management in the pre- and post-Sarbanes-Oxley periods. The Accounting Review 83 (3): 757787.

. and P. Zarowin. 2010. Accrual based and real earnings management activities around seasoned equity offerings. Journal of Accounting and Economics 50: 2-19.

Commerford, B., D. Hermanson, P. Houston, and M. Peters. 2014. Real earnings management: the auditor's perspective. Available at SSRN 2384525.

Degeorge, F., J. Patel, and R. Zeckhauser, R. 1999. Earnings managemente to exceed thresholds. The Journal of Business 72 (1): 1-33.

Ewert, R. and A. Wagenhofer. 2005. Economic Effect of Tightening Accounting Standards to Restrict Earnings Management. The Accounting Review 80 (4): 1101-1124.

Givoly, D. and D. Palmon, D. 1982. Timeliness of annual earnings announcements: some empirical evidence. The Accounting Review 57 (3): 486-508.

Graham, J., C. Harvey, and S. Rajgopal. 2005. The economic implications of corporate financial reporting. Journal of Accounting and Economics 40: 3-73. 
Gunny, K. 2010. The relation between earnings management using real activities manipulation and future performance: Evidence from meeting earnings benchmarks. Contemporary Accounting Research 27 (3): 855-888.

Järvinen, T. and E. Myllymäki. 2016. Real earnings management before and after reporting SOX 404 material weakness. Accounting Horizons 30 (1): 119-144.

Johnstone, K. 2000. Client-acceptance decisions: simultaneous effect of client business risk, audit risk, auditor business risk, and risk adaptation. Auditing: A Journal of Practice \& Theory 19 (1): 1-25

Heninger, W.G. 2001. The association between auditor litigation and abnormal accruals. The Accounting Review 76 (1):111-126.

Kasznik, R. and M. McNichols, 2002. Does meeting earnings expectation matter? Evidence from analyst forecast revisions and share prices. Journal of Accounting Research 40 (3): 727-759.

Knechel, W. R., and J. L. Payne. 2001. Additional evidence on audit report lag. Auditing: A Journal of Practice \& Theory 20 (1): 137-146.

., P. Rouse, and C. Schelleman. 2009. A modified audit production framework: evaluating the relative efficiency of audit engagements. The Accounting Review 84 (5):1607-1638.

. and D. Sharma, D. 2012. Auditor-provided nonaudit services and audit effectiveness and efficiency: evidence from pre and post SOX audit report lags. Auditing: A Journal of Practice \& Theory 31 (4): 85-114.

Kim, J. and M. Park. 2014. Real activities manipulation and auditors client retention decisions. The Accounting Review 89 (1): 367-401.

. and B. Sohn. 2013. Real earnings management and cost of capital. Journal of Accounting Public Policy 32 (6): 518-543.

Krishnan, J. and J. Yang. 2009. Recent trends in audit report and earnings announcements lags. Accounting Horizons 23 (3): 265-288.

Lambert, T., K. Jones, and J. Brazel. 2011. Unintended Consequences of Accelerated Filings: Are Mandatory Reductions in Audit Delay Associated with Reductions in Earnings Quality? Available at: https://www.researchgate.net/profile/Joseph Bra zel/publication/228302545_Unintended_Consequences_of_Accelerated_Filings_ Are_Involuntary_Reductions_in_Audit_Delay_Associated_with_Reductions_in_Earnings_Quality/links/ 0c96052aa025a83b37000000.pdf

Lee, H., and M. Son 2009. Earnings announcement timing and earnings management. Applied Financial Economics 19 (4):319-326. 
Levitt, A. 1998. The 'numbers game'. The CPA Journal 68 (12): 14.

Lobo, G. and Y. Zhao. 2013. Relation between Audit Effort and Financial Report Misstatements: Evidence from Quarterly and Annual Restatements. The Accounting Review 88 (4): 1385-1412.

Lopez, T. J., and L. Rees. 2002. The effect of beating and missing analysts' forecasts on the information content of unexpected earnings. Journal of Accounting, Auditing and Finance 17 (2): 155-84.

Mitra, S., H. Song, and J. Yang. 2015. The effect of auditing standards no. 5 on audit report lags. Accounting Horizons 29 (3): 507-527.

Munsif, V., K. Raghunandan, and D. Rama. 2012. Internal control reporting and audit report lags: further evidence. Auditing: A Journal of Practice \& Theory 31 (3): 203-218.

O'Keefe T., D. Simunic and M. Stein. 1994. The production of audit services: evidence from a major public accounting firm. Journal of Accounting Research 32 (2): 241-261.

Pratt, J. and J. Stice. 1994. The effects of client characteristics on auditor litigation risk judgments, required audit evidence, and recommended audit fees. The Accounting Review 69 (4): 639-656.

Public Company Accounting Oversight Board [PCAOB]. 2007. An audit of internal control over financial reporting that is integrated with an audit of financial statements. Auditing Standard No. 5. Release 2007-05. Washington, D.C.: PCAOB.

.2010. Auditing Standards Related to the Auditor's Assessment of and Response to Risk and Related Amendments to PCAOB Standards. http://pcaobus.org/Rules/Rulemaking/Docket\%20026/Release_2010-004_Risk_As sessment.pdf

Rickling, M., D. Rama, and K. Raghunandan. 2013. Repeatedly meeting-beating analysts forecasts and audit fees. International Journal of Business 18 (2): 120-130.

Roychowdhury, S. 2006. Earnings management through real activities manipulation. Journal of Accounting and Economics 42: 335-370.

Schelleman, C. and W. R. Knechel. 2010. Short-Term Accruals and the Pricing and Production of Audit Services. Auditing: A Journal of Practice \& Theory 29 (1): $221-250$.

Tanyi, P., K. Raghunandan, and A. Barua. 2010. Audit report lags after voluntary and involuntary auditor changes. Accounting Horizons 24 (4): 671-688. 
Wang, D. and J. Zhou. 2012. The impact of PCAOB auditing standards no. 5 on audit fees and audit quality. Accounting Horizons 26 (3): 493-511

Zang, A. 2012. Evidence on the Trade-Off between Real Activities Manipulation and accrual-Based Earnings Management. The Accounting Review 87 (2): 675-703. 


\section{Table 1 Sample Selection}

\section{Panel A: Sample Selection}

\begin{tabular}{|c|c|c|c|c|c|c|c|c|c|c|c|}
\hline & 2004 & 2005 & 2006 & 2007 & 2008 & 2009 & 2010 & 2011 & 2012 & 2013 & 2014 \\
\hline $\begin{array}{l}\text { Firms in Audit } \\
\text { Analytics with Audit } \\
\text { Opinion }\end{array}$ & 15,396 & 15,400 & 15,203 & 15,463 & 15,486 & 15,512 & 15,885 & 15,202 & 15,188 & 16,793 & 20,394 \\
\hline Less: & & & & & & & & & & & \\
\hline $\begin{array}{l}\text { Financial Firms (SIC } \\
60-69)\end{array}$ & 7,043 & 6,665 & 6,283 & 6,047 & 5,945 & 5,739 & 5,675 & 5,334 & 5,124 & 5,792 & 7,334 \\
\hline Utility Firmis (44-49) & 954 & 918 & 887 & 849 & 863 & 788 & 724 & 680 & 664 & 700 & 893 \\
\hline $\begin{array}{l}\text { OTC Firms and } \\
\text { missing SIC Code }\end{array}$ & 259 & 462 & 838 & 1,377 & 1,674 & 2,082 & 2,686 & 2,922 & 3,343 & 3,812 & 4,059 \\
\hline Duplicates & 242 & 270 & 283 & 318 & 593 & 706 & 831 & 696 & 745 & 1,435 & 2,181 \\
\hline $\begin{array}{l}\text { Merge with Compustat } \\
\text { (cikcode) }\end{array}$ & 2,105 & 2,409 & 2,372 & 2,559 & 2,359 & 2,185 & 2,034 & 1,677 & 1,420 & 1,224 & 1,949 \\
\hline Financial Data REM & 788 & 725 & 733 & 748 & 653 & 694 & 778 & 803 & 792 & 792 & 1,235 \\
\hline $\begin{array}{l}\text { Final Sample for } \\
\text { analysis }\end{array}$ & 4,005 & 3,951 & 3,807 & 3,565 & 3,399 & 3,318 & 3,157 & 3,090 & 3,100 & 3,038 & 2,743 \\
\hline
\end{tabular}




\section{Table 1 Continued}

Panel B: Audit Report Lags Mean and Median by Year

20042005

Full Sample (Large Acc,

Acc, and Non Acc)

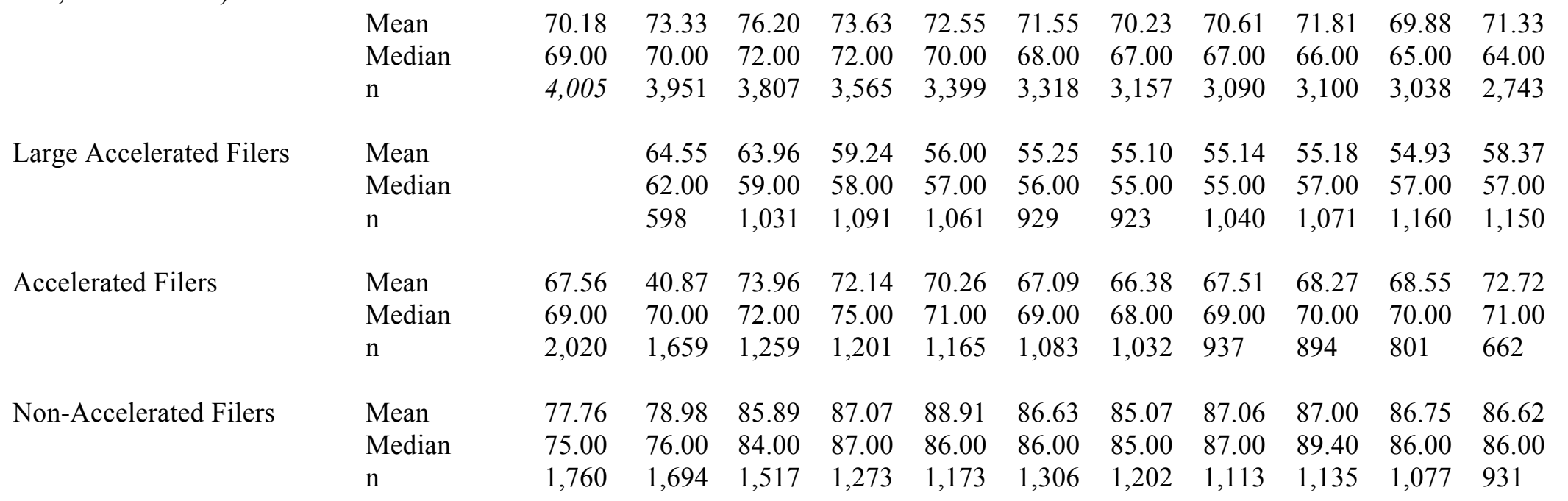


Table 2 Descriptive Statistics

Panel A: Continuous Variables

\begin{tabular}{lcrrrrr}
\multicolumn{1}{c}{ Variable } & $\mathbf{n}$ & \multicolumn{1}{c}{ Mean } & \multicolumn{1}{c}{ S.D. } & $\mathbf{2 5 \%}$ & Median & $\mathbf{7 5 \%}$ \\
\hline & & & & & & \\
LAG & 33,168 & 4.23 & 0.29 & 4.06 & 4.23 & 4.39 \\
REMCASH & 33,168 & 0.09 & 0.48 & -0.09 & -0.02 & 0.1 \\
REMDISC & 32,580 & -0.08 & 0.39 & -0.16 & 0 & 0.11 \\
REMPROD & 31,097 & 0.01 & 0.35 & -0.12 & -0.01 & 0.1 \\
REMI & 31,097 & -0.07 & 0.59 & -0.25 & -0.01 & 0.2 \\
REM2 & 31,097 & 0.01 & 0.75 & -0.27 & -0.01 & 0.23 \\
LGTA & 33,168 & 5.57 & 2.45 & 3.97 & 5.69 & 7.29 \\
LGSEGMENTS & 33,168 & 1.15 & 0.85 & 0.69 & 0.69 & 2.08 \\
LGAUDITFEE & 33,168 & 13.44 & 1.43 & 12.47 & 13.55 & 14.39 \\
CR & 33,168 & 2.74 & 2.24 & 1.28 & 2.01 & 3.36 \\
ROA & 33,168 & -0.08 & 0.33 & -0.06 & 0.02 & 0.05 \\
LEV & 33,168 & 0.53 & 0.3 & 0.31 & 0.5 & 0.7 \\
EARGROWTH & 33,168 & -0.12 & 4.46 & -0.72 & -0.05 & 0.43 \\
ACCRUALS & 33,168 & 0.11 & 0.06 & 0.04 & 0.1 & 0.18
\end{tabular}

Panel B: Indicator Variables

\begin{tabular}{lrr}
\multicolumn{1}{c}{ Variable } & n & $\begin{array}{r}\text { Rate of } \\
\text { Occurance }\end{array}$ \\
\hline FOROPS & 33,168 & $49 \%$ \\
PENSION & 33,168 & $10 \%$ \\
GC & 33,168 & $9 \%$ \\
LOSS & 33,168 & $39 \%$ \\
EXITEM & 33,168 & $18 \%$ \\
ACQ & 33,168 & $16 \%$ \\
BIG4 & 33,168 & $22 \%$ \\
AUCHG & 33,168 & $6 \%$ \\
NASDAQ & 33,168 & $55 \%$ \\
HIGHTECH & 33,168 & $39 \%$ \\
HIGHGROWTH & 33,168 & $26 \%$ \\
HIGHTLIT & 33,168 & $52 \%$ \\
BUSY & 33,168 & $67 \%$
\end{tabular}


Table 3 Pearson Correlations

\begin{tabular}{|c|c|c|c|c|c|c|c|c|c|c|}
\hline & $L A G$ & $\begin{array}{l}\text { REM } \\
C A S H\end{array}$ & $\begin{array}{l}\text { REM } \\
D I S C\end{array}$ & $\begin{array}{l}R E M \\
P R O D\end{array}$ & REM1 & REM2 & $L G T A$ & $\begin{array}{l}L G S E G \\
M E N T S\end{array}$ & $\begin{array}{l}L G \\
A U D I T \\
F E E\end{array}$ & $C R$ \\
\hline$L A G$ & 1 & & & & & & & & & \\
\hline \multirow[t]{2}{*}{ REMCASH } & 0.25 & 1 & & & & & & & & \\
\hline & 0.00 & & & & & & & & & \\
\hline \multirow[t]{2}{*}{ REMDISC } & -0.15 & -0.50 & 1 & & & & & & & \\
\hline & 0.00 & 0.00 & & & & & & & & \\
\hline \multirow[t]{2}{*}{ REMPROD } & 0.10 & 0.36 & 0.24 & 1 & & & & & & \\
\hline & 0.00 & 0.00 & 0.00 & & & & & & & \\
\hline \multirow[t]{2}{*}{ REM1 } & -0.05 & -0.19 & 0.88 & 0.68 & 1 & & & & & \\
\hline & 0.00 & 0.00 & 0.00 & 0.00 & & & & & & \\
\hline \multirow[t]{2}{*}{ REM2 } & 0.10 & 0.41 & 0.52 & 0.85 & 0.81 & 1 & & & & \\
\hline & 0.00 & 0.00 & 0.00 & 0.00 & 0.00 & & & & & \\
\hline \multirow[t]{2}{*}{$L G T A$} & -0.52 & -0.44 & 0.30 & -0.08 & 0.18 & -0.09 & 1 & & & \\
\hline & 0.00 & 0.00 & 0.00 & 0.00 & 0.00 & 0.00 & & & & \\
\hline \multirow[t]{2}{*}{ LGSEGMENTS } & -0.12 & -0.13 & 0.14 & 0.01 & 0.11 & 0.03 & 0.25 & 1 & & \\
\hline & 0.00 & 0.00 & 0.00 & -0.01 & 0.00 & 0.00 & 0.00 & & & \\
\hline \multirow[t]{2}{*}{ LGAUDITFEE } & -0.45 & -0.33 & 0.20 & -0.07 & 0.11 & -0.09 & 0.89 & 0.25 & 1 & \\
\hline & 0.00 & 0.00 & 0.00 & 0.00 & 0.00 & 0.00 & 0.00 & 0.00 & & \\
\hline \multirow[t]{2}{*}{$C R$} & -0.05 & -0.04 & 0.05 & 0.00 & 0.04 & 0.00 & -0.09 & -0.07 & -0.13 & 1 \\
\hline & 0.00 & 0.00 & 0.00 & -0.81 & 0.00 & -0.72 & 0.00 & 0.00 & 0.00 & \\
\hline \multirow[t]{2}{*}{$R O A$} & -0.27 & -0.71 & 0.41 & -0.25 & 0.19 & -0.25 & 0.47 & 0.13 & 0.34 & 0.13 \\
\hline & 0.00 & 0.00 & 0.00 & 0.00 & 0.00 & 0.00 & 0.00 & 0.00 & 0.00 & 0.00 \\
\hline \multirow[t]{2}{*}{$L E V$} & 0.21 & 0.47 & -0.22 & 0.11 & -0.11 & 0.18 & -0.34 & -0.08 & -0.23 & -0.25 \\
\hline & 0.00 & 0.00 & 0.00 & 0.00 & 0.00 & 0.00 & 0.00 & 0.00 & 0.00 & 0.00 \\
\hline \multirow[t]{2}{*}{ EARGROWTH } & 0.00 & 0.03 & -0.03 & 0.02 & -0.01 & 0.01 & -0.01 & -0.01 & -0.01 & 0.01 \\
\hline & -0.40 & 0.00 & 0.00 & 0.00 & -0.22 & -0.06 & -0.32 & -0.01 & -0.02 & -0.11 \\
\hline
\end{tabular}


Table 3 Continued

\begin{tabular}{|c|c|c|c|c|c|c|c|c|c|c|}
\hline & $L A G$ & $\begin{array}{l}R E M \\
C A S H\end{array}$ & $\begin{array}{l}R E M \\
D I S C\end{array}$ & $\begin{array}{l}\text { REM } \\
P R O D\end{array}$ & REM1 & REM2 & $L G T A$ & $\begin{array}{l}L G S E G \\
M E N T S\end{array}$ & $\begin{array}{l}L G \\
A U D I T \\
F E E\end{array}$ & $C R$ \\
\hline \multirow[t]{2}{*}{ FOROPS } & -0.28 & -0.23 & 0.13 & -0.10 & 0.05 & -0.10 & 0.48 & 0.16 & 0.56 & -0.04 \\
\hline & 0.00 & 0.00 & 0.00 & 0.00 & 0.00 & 0.00 & 0.00 & 0.00 & 0.00 & 0.00 \\
\hline \multirow[t]{2}{*}{ PENSION } & -0.12 & -0.08 & 0.08 & 0.00 & 0.06 & 0.01 & 0.22 & 0.13 & 0.23 & -0.07 \\
\hline & 0.00 & 0.00 & 0.00 & -0.66 & 0.00 & -0.03 & 0.00 & 0.00 & 0.00 & 0.00 \\
\hline \multirow[t]{2}{*}{$G C$} & 0.33 & 0.45 & -0.24 & 0.16 & -0.10 & 0.17 & -0.47 & -0.12 & -0.38 & -0.19 \\
\hline & 0.00 & 0.00 & 0.00 & 0.00 & 0.00 & 0.00 & 0.00 & 0.00 & 0.00 & 0.00 \\
\hline \multirow[t]{2}{*}{ LOSS } & 0.31 & 0.36 & -0.22 & 0.16 & -0.08 & 0.14 & -0.41 & -0.16 & -0.30 & -0.02 \\
\hline & 0.00 & 0.00 & 0.00 & 0.00 & 0.00 & 0.00 & 0.00 & 0.00 & 0.00 & -0.01 \\
\hline \multirow[t]{2}{*}{ EXITEM } & -0.04 & -0.05 & 0.09 & 0.02 & 0.08 & 0.05 & 0.17 & 0.16 & 0.20 & -0.10 \\
\hline & 0.00 & 0.00 & 0.00 & 0.00 & 0.00 & 0.00 & 0.00 & 0.00 & 0.00 & 0.00 \\
\hline \multirow[t]{2}{*}{$A C Q$} & -0.13 & -0.09 & 0.05 & -0.02 & 0.03 & -0.03 & 0.24 & 0.06 & 0.24 & -0.06 \\
\hline & 0.00 & 0.00 & 0.00 & 0.00 & 0.00 & 0.00 & 0.00 & 0.00 & 0.00 & 0.00 \\
\hline \multirow[t]{2}{*}{$B I G 4$} & -0.19 & -0.07 & 0.04 & -0.01 & 0.02 & -0.02 & 0.21 & 0.01 & 0.22 & 0.03 \\
\hline & 0.00 & 0.00 & 0.00 & -0.05 & 0.00 & 0.00 & 0.00 & -0.02 & 0.00 & 0.00 \\
\hline \multirow[t]{2}{*}{$A U C H G$} & 0.09 & 0.01 & 0.00 & 0.01 & 0.00 & 0.01 & -0.07 & -0.02 & -0.06 & 0.01 \\
\hline & 0.00 & -0.12 & -0.95 & -0.13 & -0.46 & -0.08 & 0.00 & 0.00 & 0.00 & -0.32 \\
\hline \multirow[t]{2}{*}{$N A S D A Q$} & -0.39 & -0.25 & 0.13 & -0.08 & 0.07 & -0.08 & 0.55 & 0.17 & 0.52 & 0.00 \\
\hline & 0.00 & 0.00 & 0.00 & 0.00 & 0.00 & 0.00 & 0.00 & 0.00 & 0.00 & -0.99 \\
\hline \multirow[t]{2}{*}{ HIGHTECH } & 0.05 & 0.12 & -0.16 & -0.02 & -0.13 & -0.05 & -0.22 & -0.14 & -0.10 & 0.22 \\
\hline & 0.00 & 0.00 & 0.00 & 0.00 & 0.00 & 0.00 & 0.00 & 0.00 & 0.00 & 0.00 \\
\hline \multirow[t]{2}{*}{ HIGHGROWTH } & 0.03 & -0.02 & -0.04 & -0.05 & -0.05 & -0.06 & -0.06 & 0.01 & 0.01 & -0.09 \\
\hline & 0.00 & 0.00 & 0.00 & 0.00 & 0.00 & 0.00 & 0.00 & -0.28 & -0.17 & 0.00 \\
\hline \multirow[t]{2}{*}{ HIGHTLIT } & 0.04 & 0.11 & -0.10 & 0.03 & -0.05 & 0.02 & -0.20 & -0.07 & -0.06 & 0.20 \\
\hline & 0.00 & 0.00 & 0.00 & 0.00 & 0.00 & -0.01 & 0.00 & 0.00 & 0.00 & 0.00 \\
\hline \multirow[t]{2}{*}{$B U S Y$} & -0.09 & -0.06 & 0.01 & 0.00 & 0.01 & -0.02 & 0.16 & 0.00 & 0.17 & 0.00 \\
\hline & 0.00 & 0.00 & -0.03 & -0.67 & -0.32 & 0.00 & 0.00 & -0.40 & 0.00 & -0.89 \\
\hline
\end{tabular}


Table 3 Continued

\begin{tabular}{|c|c|c|c|c|c|c|c|c|c|c|c|}
\hline$R O A$ & ${ }_{1}^{R O A}$ & $L E V$ & $\begin{array}{l}\text { EAR } \\
\text { GROWTH }\end{array}$ & FOROPS & PENSION & $G C$ & LOSS & EXITEM & $A C Q$ & $B I G 4$ & $A U C H G$ \\
\hline \multirow[t]{2}{*}{$L E V$} & -0.73 & 1 & & & & & & & & & \\
\hline & 0.00 & & & & & & & & & & \\
\hline \multirow[t]{2}{*}{ EARGROWTH } & -0.03 & 0.01 & 1 & & & & & & & & \\
\hline & 0.00 & -0.15 & & & & & & & & & \\
\hline \multirow[t]{2}{*}{ FOROPS } & 0.22 & -0.14 & -0.02 & 1 & & & & & & & \\
\hline & 0.00 & 0.00 & 0.00 & & & & & & & & \\
\hline \multirow[t]{2}{*}{ PENSION } & 0.08 & -0.03 & -0.01 & 0.17 & 1 & & & & & & \\
\hline & 0.00 & 0.00 & -0.08 & 0.00 & & & & & & & \\
\hline \multirow[t]{2}{*}{$G C$} & -0.55 & 0.49 & 0.02 & -0.24 & -0.08 & 1 & & & & & \\
\hline & 0.00 & 0.00 & 0.00 & 0.00 & 0.00 & & & & & & \\
\hline \multirow[t]{2}{*}{$L O S S$} & -0.39 & 0.20 & -0.05 & -0.23 & -0.09 & 0.33 & 1 & & & & \\
\hline & 0.00 & 0.00 & 0.00 & 0.00 & 0.00 & 0.00 & & & & & \\
\hline \multirow[t]{2}{*}{ EXITEM } & 0.06 & -0.01 & -0.02 & 0.07 & 0.08 & -0.03 & -0.02 & 1 & & & \\
\hline & 0.00 & -0.08 & -0.01 & 0.00 & 0.00 & 0.00 & -0.01 & & & & \\
\hline \multirow[t]{2}{*}{$A C Q$} & 0.09 & -0.06 & 0.00 & 0.19 & 0.04 & -0.10 & -0.08 & 0.03 & 1 & & \\
\hline & 0.00 & 0.00 & -0.56 & 0.00 & 0.00 & 0.00 & 0.00 & 0.00 & & & \\
\hline \multirow[t]{2}{*}{$B I G 4$} & 0.08 & -0.07 & -0.01 & 0.09 & 0.02 & -0.12 & -0.05 & 0.01 & 0.05 & 1 & \\
\hline & 0.00 & 0.00 & -0.30 & 0.00 & 0.00 & 0.00 & 0.00 & -0.23 & 0.00 & & \\
\hline \multirow[t]{2}{*}{$A U C H G$} & 0.00 & -0.02 & -0.01 & -0.03 & -0.02 & 0.01 & 0.05 & 0.00 & -0.02 & -0.06 & 1 \\
\hline & -0.47 & 0.00 & -0.10 & 0.00 & 0.00 & -0.02 & 0.00 & -0.43 & 0.00 & 0.00 & \\
\hline \multirow[t]{2}{*}{$N A S D A Q$} & 0.24 & -0.18 & 0.00 & 0.32 & 0.13 & -0.30 & -0.30 & 0.05 & 0.18 & 0.17 & -0.06 \\
\hline & 0.00 & 0.00 & -0.82 & 0.00 & 0.00 & 0.00 & 0.00 & 0.00 & 0.00 & 0.00 & 0.00 \\
\hline \multirow[t]{2}{*}{ HIGHTECH } & -0.12 & 0.02 & 0.00 & 0.05 & -0.11 & 0.07 & 0.19 & -0.13 & 0.03 & 0.01 & 0.03 \\
\hline & 0.00 & 0.00 & -0.59 & 0.00 & 0.00 & 0.00 & 0.00 & 0.00 & 0.00 & -0.01 & 0.00 \\
\hline
\end{tabular}


Table 3 Continued

\begin{tabular}{|c|c|c|c|c|c|c|c|c|c|c|c|}
\hline & $R O A$ & $L E V$ & $\begin{array}{l}\text { EAR } \\
\text { GROWTH }\end{array}$ & FOROPS & PENSION & $G C$ & $L O S S$ & EXITEM & $A C Q$ & $B I G 4$ & $A U C H G$ \\
\hline \multirow[t]{2}{*}{ HIGHGROWTH } & -0.02 & 0.03 & 0.01 & 0.08 & -0.05 & 0.00 & 0.02 & 0.00 & 0.06 & 0.00 & 0.00 \\
\hline & 0.00 & 0.00 & -0.32 & 0.00 & 0.00 & -0.85 & 0.00 & -0.64 & 0.00 & -0.49 & -0.92 \\
\hline \multirow[t]{2}{*}{ HIGHTLIT } & -0.12 & 0.02 & 0.00 & 0.12 & -0.06 & 0.06 & 0.15 & -0.10 & 0.03 & 0.00 & 0.02 \\
\hline & 0.00 & 0.00 & -0.47 & 0.00 & 0.00 & 0.00 & 0.00 & 0.00 & 0.00 & -0.64 & 0.00 \\
\hline \multirow[t]{2}{*}{$B U S Y$} & 0.08 & -0.07 & 0.01 & 0.04 & 0.00 & -0.09 & -0.01 & 0.03 & 0.04 & 0.06 & -0.01 \\
\hline & 0.00 & 0.00 & -0.13 & 0.00 & -0.91 & 0.00 & -0.02 & 0.00 & 0.00 & 0.00 & -0.03 \\
\hline
\end{tabular}

\begin{tabular}{|c|c|c|c|c|c|}
\hline & $N A S D A Q$ & $\begin{array}{l}H I G H \\
T E C H\end{array}$ & $\begin{array}{l}\text { HIGH } \\
\text { GROWTH }\end{array}$ & $\begin{array}{l}H I G H \\
L I T\end{array}$ & $B U S Y$ \\
\hline$N A S D A Q$ & 1 & & & & \\
\hline \multirow[t]{2}{*}{ HIGHTECH } & -0.08 & 1 & & & \\
\hline & 0.00 & & & & \\
\hline \multirow[t]{2}{*}{ HIGHGROWTH } & -0.03 & 0.18 & 1 & & \\
\hline & 0.00 & 0.00 & & & \\
\hline \multirow[t]{2}{*}{ HIGHTLIT } & -0.07 & 0.72 & 0.36 & 1 & \\
\hline & 0.00 & 0.00 & 0.00 & & \\
\hline \multirow{2}{*}{$B U S Y$} & 0.14 & -0.02 & 0.01 & -0.02 & \\
\hline & 0.00 & 0.00 & -0.20 & 0 & \\
\hline
\end{tabular}


Table 4 Real Earnings Management and Audit Report Lags

\begin{tabular}{|c|c|c|c|c|c|}
\hline & 1 & 2 & 3 & 4 & 5 \\
\hline REMCASH & $\begin{array}{c}-0.00248 \\
(-0.61)\end{array}$ & & & & \\
\hline REMDISC & & $\begin{array}{c}0.0200^{* * *} \\
-5.21\end{array}$ & & & \\
\hline REMPROD & & & $\begin{array}{c}0.0321^{* * *} \\
-7.81\end{array}$ & & \\
\hline REM1 & & & & $\begin{array}{c}0.0225^{* * *} \\
-9.73\end{array}$ & \\
\hline REM2 & & & & & $\begin{array}{c}0.0146^{* * *} \\
-7.3\end{array}$ \\
\hline LGTA & $\begin{array}{c}-0.0614^{* * *} \\
(-41.96)\end{array}$ & $\begin{array}{c}-0.0615^{* * *} \\
(-41.13)\end{array}$ & $\begin{array}{c}-0.0666^{* * *} \\
(-42.30)\end{array}$ & $\begin{array}{c}-0.0674^{* * *} \\
(-45.76)\end{array}$ & $\begin{array}{c}-0.0662^{* * *} \\
(-45.25)\end{array}$ \\
\hline LGSEGMENTS & $\begin{array}{c}0.0059^{* * *} \\
-3.55\end{array}$ & $\begin{array}{c}0.0051^{* * * *} \\
-2.99\end{array}$ & $\begin{array}{c}0.0061^{* * *} \\
-3.4\end{array}$ & $\begin{array}{c}0.0042^{* * *} \\
-2.58\end{array}$ & $\begin{array}{c}0.0046^{* * *} \\
-2.8\end{array}$ \\
\hline LGAUDITFEE & $\begin{array}{c}0.0207^{* * *} \\
-8.71\end{array}$ & $\begin{array}{c}0.0214^{* * *} \\
-8.9\end{array}$ & $\begin{array}{c}0.0321^{* * *} \\
-12.62\end{array}$ & $\begin{array}{c}0.0329^{* * *} \\
-13.83\end{array}$ & $\begin{array}{c}0.0317^{* * *} \\
-13.33\end{array}$ \\
\hline CR & $\begin{array}{c}-0.0044^{* * *} \\
(-5.97)\end{array}$ & $\begin{array}{c}-0.0048^{* * *} \\
(-6.39)\end{array}$ & $\begin{array}{c}-0.0054^{* * *} \\
(-6.84)\end{array}$ & $\begin{array}{c}-0.0047^{* * *} \\
(-6.42)\end{array}$ & $\begin{array}{c}-0.0047^{* * *} \\
(-6.41)\end{array}$ \\
\hline ROA & $\begin{array}{c}0.0693^{* * *} \\
-9.35\end{array}$ & $\begin{array}{c}0.0638^{* * *} \\
-10\end{array}$ & $\begin{array}{c}0.0853^{* * *} \\
-12.9\end{array}$ & $\begin{array}{c}0.0746^{* * *} \\
-11.89\end{array}$ & $\begin{array}{c}0.0878^{* * *} \\
-13.22\end{array}$ \\
\hline LEV & $\begin{array}{c}0.0621^{* * *} \\
-10.41\end{array}$ & $\begin{array}{c}0.0594^{* * *} \\
-9.84\end{array}$ & $\begin{array}{c}0.0428^{* * *} \\
-6.77\end{array}$ & $\begin{array}{c}0.0476^{* * *} \\
-8.04\end{array}$ & $\begin{array}{c}0.0470^{* * *} \\
-7.93\end{array}$ \\
\hline EARGROWTH & $\begin{array}{c}-0.0000 \\
(-0.13)\end{array}$ & $\begin{array}{c}0.0000 \\
-0.05\end{array}$ & $\begin{array}{c}-0.0002 \\
(-0.55)\end{array}$ & $\begin{array}{c}-0.0002 \\
(-0.87)\end{array}$ & $\begin{array}{c}-0.0002 \\
(-0.90)\end{array}$ \\
\hline FOROPS & $\begin{array}{c}-0.0163^{* * *} \\
(-4.81)\end{array}$ & $\begin{array}{c}-0.0175^{* * *} \\
(-5.10)\end{array}$ & $\begin{array}{c}-0.0164^{* * *} \\
(-4.56)\end{array}$ & $\begin{array}{c}-0.0191^{* * *} \\
(-5.73)\end{array}$ & $\begin{array}{c}-0.0188^{* * *} \\
(-5.65)\end{array}$ \\
\hline PENSION & $\begin{array}{c}-0.0158^{* * *} \\
(-3.40)\end{array}$ & $\begin{array}{c}-0.0151^{* * *} \\
(-3.22)\end{array}$ & $\begin{array}{c}-0.0179^{* * *} \\
(-3.59)\end{array}$ & $\begin{array}{c}-0.0173^{* * *} \\
(-3.84)\end{array}$ & $\begin{array}{c}-0.0172^{* * *} \\
(-3.81)\end{array}$ \\
\hline $\mathrm{GC}$ & $\begin{array}{c}0.0734^{* * *} \\
-11.27\end{array}$ & $\begin{array}{c}0.0707^{* * *} \\
-10.75\end{array}$ & $\begin{array}{c}0.0905^{* * *} \\
-13.59\end{array}$ & $\begin{array}{c}0.0859^{* * *} \\
-13.25\end{array}$ & $\begin{array}{c}0.0867^{* * *} \\
-13.37\end{array}$ \\
\hline LOSS & $\begin{array}{c}0.0687^{* * *} \\
-20.19\end{array}$ & $\begin{array}{c}0.0687^{* * *} \\
-20.05\end{array}$ & $\begin{array}{c}0.0719^{* * *} \\
-20.47\end{array}$ & $\begin{array}{c}0.0682^{* * *} \\
-20.48\end{array}$ & $\begin{array}{c}0.0689^{* * *} \\
-20.67\end{array}$ \\
\hline EXITEM & $\begin{array}{c}0.0099^{* * *} \\
-2.67\end{array}$ & $\begin{array}{c}0.0076^{* *} \\
-2.03\end{array}$ & $\begin{array}{c}0.0089^{* *} \\
-2.27\end{array}$ & $\begin{array}{c}0.0081^{* *} \\
-2.23\end{array}$ & $\begin{array}{c}0.0087^{* *} \\
-2.39\end{array}$ \\
\hline ACQ & $\begin{array}{c}-0.0053 \\
(-1.41)\end{array}$ & $\begin{array}{c}-0.0064^{*} \\
(-1.67)\end{array}$ & $\begin{array}{c}-0.0045 \\
(-1.09)\end{array}$ & $\begin{array}{c}-0.0071^{*} \\
(-1.90)\end{array}$ & $\begin{array}{c}-0.0071^{*} \\
(-1.89)\end{array}$ \\
\hline BIG4 & $\begin{array}{c}-0.0600^{* * *} \\
(-17.63)\end{array}$ & $\begin{array}{c}-0.0617^{* * *} \\
(-17.93)\end{array}$ & $\begin{array}{c}-0.0696^{* * *} \\
(-19.29)\end{array}$ & $\begin{array}{c}-0.0670^{* * *} \\
(-20.08)\end{array}$ & $\begin{array}{c}-0.0671^{* * *} \\
(-20.10)\end{array}$ \\
\hline AUCHG & $\begin{array}{c}0.0591^{* * *} \\
-10.35\end{array}$ & $\begin{array}{c}0.0587^{* * *} \\
-10.17\end{array}$ & $\begin{array}{c}0.0599^{* * * *} \\
-10.09\end{array}$ & $\begin{array}{c}0.0592^{* * * *} \\
-10.6\end{array}$ & $\begin{array}{c}0.0595^{* * *} \\
-10.64\end{array}$ \\
\hline HIGHTECH & $\begin{array}{c}-0.0134^{* * *} \\
(-3.27)\end{array}$ & $\begin{array}{c}-0.0101^{* *} \\
(-2.44)\end{array}$ & $\begin{array}{c}-0.0124^{* * *} \\
(-2.90)\end{array}$ & $\begin{array}{c}-0.0095^{* *} \\
(-2.37)\end{array}$ & $\begin{array}{c}-0.0111^{* * *} \\
(-2.77)\end{array}$ \\
\hline HIGHGROWTH & $\begin{array}{c}0.0056 \\
-1.63\end{array}$ & $\begin{array}{c}0.0065^{*} \\
-1.89\end{array}$ & $\begin{array}{c}0.0037 \\
-1.03\end{array}$ & $\begin{array}{c}0.0056^{*} \\
-1.66\end{array}$ & $\begin{array}{c}0.0056^{*} \\
-1.67\end{array}$ \\
\hline HIGHTLIT & $\begin{array}{c}-0.0294^{* * *} \\
(-6.87)\end{array}$ & $\begin{array}{c}-0.0322^{* * *} \\
(-7.45)\end{array}$ & $\begin{array}{c}-0.0316^{* * *} \\
(-7.03)\end{array}$ & $\begin{array}{c}-0.0340^{* * *} \\
(-8.11)\end{array}$ & $\begin{array}{c}-0.0326^{* * *} \\
(-7.78)\end{array}$ \\
\hline
\end{tabular}


Table 4 Continued

\begin{tabular}{lccccc} 
& 1 & 2 & 3 & 4 & 5 \\
BUSY & $-0.0065^{* *}$ & $-0.0051^{*}$ & $-0.0084^{* * *}$ & $-0.0067^{* *}$ & $-0.0070^{* *}$ \\
& $(-2.21)^{* * *}$ & $(-1.69)^{* * *}$ & $(-2.69)$ & $(-2.33)$ & $(-2.40)^{*}$ \\
ABSACCR & $0.1630^{* * *}$ & $0.1750^{* *}$ & 0.0414 & $0.0438^{*}$ & $0.0445^{*}$ \\
& -6.61 & -7 & -1.59 & -1.8 & -1.82 \\
CONSTANT & $4.263^{* * *}$ & $4.257^{* * *}$ & $4.160^{* * *}$ & $4.155^{* * *}$ & $4.164^{* * *}$ \\
& -172.16 & -169.78 & -156.85 & -167.81 & -168.32 \\
\hline$N$ & 33168 & 32580 & 27346 & 31097 & 31097 \\
adj. $R^{2}$ & 0.289 & 0.287 & 0.31 & 0.307 & 0.307 \\
\hline
\end{tabular}

$t$ statistics in parentheses

${ }^{*} p<0.10,{ }^{* *} p<0.05,{ }^{* * *} p<0.01$ 
Table 5 Regression Suspects VS Non-Suspects (Subsample)

\begin{tabular}{|c|c|c|c|c|c|c|c|c|c|c|}
\hline & Suspects & Suspects & Suspects & Suspects & Suspects & $\begin{array}{c}\text { Non } \\
\text { Suspects } \\
\end{array}$ & $\begin{array}{c}\text { Non } \\
\text { Suspects }\end{array}$ & $\begin{array}{c}\text { Non } \\
\text { Suspects }\end{array}$ & $\begin{array}{c}\text { Non } \\
\text { Suspects }\end{array}$ & $\begin{array}{c}\text { Non } \\
\text { Suspects }\end{array}$ \\
\hline \multirow{2}{*}{ REMCASH } & 0.0479 & & & & & -0.0026 & & & & \\
\hline & -1.5 & & & & & $(-0.63)$ & & & & \\
\hline \multirow{2}{*}{ REMDISC } & & $0.0588^{* * *}$ & & & & & $0.0175^{* * *}$ & & & \\
\hline & & -3.32 & & & & & -4.43 & & & \\
\hline \multirow{2}{*}{ REMPROD } & & & $0.0695^{* * *}$ & & & & & $0.0321^{* * *}$ & & \\
\hline & & & -3.77 & & & & & -7.81 & & \\
\hline \multirow{2}{*}{ REM1 } & & & & $0.0424^{* * *}$ & & & & & $0.0211^{* * *}$ & \\
\hline & & & & -4.3 & & & & & -8.83 & \\
\hline \multirow{2}{*}{ REM2 } & & & & & $0.0379^{* * *}$ & & & & & $0.0133^{* * *}$ \\
\hline & & & & & -4.26 & & & & & -6.49 \\
\hline \multirow{2}{*}{ LGTA } & $-0.0663^{* * *}$ & $-0.070^{* * *}$ & $-0.070^{* * *}$ & $-0.072^{* * *}$ & $-0.071^{* * *}$ & $-0.061^{* * *}$ & $-0.0611^{* * *}$ & $-0.066^{* * *}$ & $-0.067^{* * *}$ & $-0.066^{* * *}$ \\
\hline & $(-16.06)$ & $(-16.52)$ & $(-17.16)$ & $(-17.35)$ & $(-17.22)$ & $(-38.92)$ & $(-38.09)$ & $(-42.30)$ & $(-42.61)$ & $(-42.14)$ \\
\hline \multirow{2}{*}{ LGSEGMENTS } & -0.0012 & -0.0025 & -0.0047 & -0.0050 & -0.0050 & $0.0071^{* * *}$ & $0.0062^{* * *}$ & $0.0061^{* * *}$ & $0.0057^{* * *}$ & $0.0061^{* * *}$ \\
\hline & $(-0.34)$ & $(-0.59)$ & $(-1.14)$ & $(-1.23)$ & $(-1.21)$ & -3.84 & -3.33 & -3.4 & -3.17 & -3.38 \\
\hline \multirow{2}{*}{ LGAUDITFEE } & $0.0241^{* * *}$ & $0.0289^{* * * *}$ & $0.0340^{* * *}$ & $0.0357^{* * *}$ & $0.0346^{* * *}$ & $0.0209^{* * *}$ & $0.0213^{* * *}$ & $0.0321^{* * *}$ & $0.0334^{* * *}$ & $0.0321^{* * *}$ \\
\hline & -3.63 & -4.28 & -5.14 & -5.37 & -5.22 & -8.21 & -8.28 & -12.62 & -13.08 & -12.62 \\
\hline \multirow{2}{*}{$\mathrm{CR}$} & 0.0015 & 0.0008 & 0.0011 & 0.0007 & 0.0008 & $-0.0054^{* * *}$ & $-0.0057^{* * *}$ & $-0.0054^{* * *}$ & $-0.0055^{* * *}$ & $-0.0055^{* * *}$ \\
\hline & -0.77 & -0.4 & -0.57 & -0.37 & -0.4 & $(-6.71)$ & $(-7.05)$ & $(-6.84)$ & $(-6.98)$ & $(-6.98)$ \\
\hline \multirow{2}{*}{ ROA } & -0.0429 & -0.0861 & 0.0310 & 0.0055 & 0.0366 & $0.0698^{* * *}$ & $0.0651^{* * *}$ & $0.0853^{* * *}$ & $0.0754^{* * *}$ & $0.0874^{* * *}$ \\
\hline & $(-0.62)$ & $(-1.33)$ & -0.48 & -0.09 & -0.56 & -9.23 & -9.95 & -12.9 & -11.74 & -12.85 \\
\hline \multirow{2}{*}{ LEV } & $0.1110^{* * *}$ & $0.1110^{* * *}$ & $0.0842^{* * *}$ & $0.0827^{* * *}$ & $0.0810^{* * *}$ & $0.0543^{* * *}$ & $0.0517^{* * *}$ & $0.0428^{* * *}$ & $0.0418^{* * *}$ & $0.0411^{* * *}$ \\
\hline & -6.21 & -6.14 & -4.71 & -4.63 & -4.53 & -8.52 & -8.03 & -6.77 & -6.62 & -6.51 \\
\hline \multirow{2}{*}{ EARGROWTH } & $-0.0060^{* *}$ & $-0.0060^{* *}$ & $-0.0073^{* * *}$ & $-0.0074^{* * *}$ & $-0.0074^{* * *}$ & 0.0000 & 0.0001 & -0.0002 & -0.0001 & -0.0001 \\
\hline & $(-2.21)$ & $(-2.13)$ & $(-2.78)$ & $(-2.81)$ & $(-2.82)$ & -0.26 & -0.41 & $(-0.55)$ & $(-0.42)$ & $(-0.45)$ \\
\hline FOROPS & $\begin{array}{c}-0.0292^{* * *} \\
(-3.26)\end{array}$ & $\begin{array}{c}-0.0312^{* * *} \\
(-3.42)\end{array}$ & $\begin{array}{c}-0.0355^{* * *} \\
(-3.97)\end{array}$ & $\begin{array}{c}-0.0351^{* * *} \\
(-3.93)\end{array}$ & $\begin{array}{c}-0.0352^{* * *} \\
(-3.94)\end{array}$ & $\begin{array}{c}-0.0148^{* * *} \\
(-4.03)\end{array}$ & $\begin{array}{c}-0.0157^{* * *} \\
(-4.23)\end{array}$ & $\begin{array}{c}-0.0164^{* * *} \\
(-4.56)\end{array}$ & $\begin{array}{c}-0.0171^{* * *} \\
(-4.75)\end{array}$ & $\begin{array}{r}-0.0168^{* * *} \\
(-4.68)\end{array}$ \\
\hline
\end{tabular}




\begin{tabular}{|c|c|c|c|c|c|c|c|c|c|c|}
\hline \multirow{2}{*}{ PENSION } & -0.0169 & -0.0151 & -0.0147 & -0.0150 & -0.0151 & $-0.0160^{* * *}$ & $-0.0156^{* * *}$ & $-0.0179^{* * *}$ & $-0.0182^{* * *}$ & $-0.0181^{* * *}$ \\
\hline & $(-1.60)$ & $(-1.40)$ & $(-1.41)$ & $(-1.44)$ & $(-1.45)$ & $(-3.12)$ & $(-3.01)$ & $(-3.59)$ & $(-3.66)$ & $(-3.63)$ \\
\hline \multirow{2}{*}{ GC } & 0.0229 & 0.0164 & 0.0509 & 0.0451 & 0.0464 & $0.0765^{* * *}$ & $0.0739^{* * *}$ & $0.0905^{* * *}$ & $0.0882^{* * *}$ & $0.0891^{* * *}$ \\
\hline & -0.68 & -0.49 & -1.55 & -1.37 & -1.41 & -11.4 & -10.93 & -13.59 & -13.23 & -13.35 \\
\hline \multirow{2}{*}{ LOSS } & $0.0319^{* *}$ & $0.0342^{* *}$ & $0.0358^{* *}$ & $0.0371^{* * *}$ & $0.0371^{* * *}$ & $0.0735^{* * *}$ & $0.0731^{* * *}$ & $0.0719^{* * *}$ & $0.0726^{* * *}$ & $0.0734^{* * *}$ \\
\hline & -2.25 & -2.39 & -2.53 & -2.62 & -2.62 & -20.48 & -20.26 & -20.47 & -20.7 & -20.91 \\
\hline \multirow{2}{*}{ EXITEM } & 0.0053 & 0.0052 & 0.0088 & 0.0077 & 0.0077 & $0.0103^{* *}$ & $0.0076^{*}$ & $0.0089^{* *}$ & $0.0078^{* *}$ & $0.0083^{* *}$ \\
\hline & -0.55 & -0.55 & -0.92 & -0.81 & -0.81 & -2.57 & -1.88 & -2.27 & -1.98 & -2.13 \\
\hline \multirow{2}{*}{$\mathrm{ACQ}$} & $-0.0164^{*}$ & $-0.0203^{* *}$ & $-0.0211^{* *}$ & $-0.0212^{* *}$ & $-0.0211^{* *}$ & -0.0036 & -0.0041 & -0.0045 & -0.0046 & -0.0046 \\
\hline & $(-1.80)$ & $(-2.21)$ & $(-2.34)$ & $(-2.36)$ & $(-2.34)$ & $(-0.86)$ & $(-0.97)$ & $(-1.09)$ & $(-1.13)$ & $(-1.13)$ \\
\hline \multirow{2}{*}{ BIG4 } & $-0.0376^{* * *}$ & $-0.0389^{* * *}$ & $-0.0492^{* * *}$ & $-0.0488^{* * *}$ & $-0.0490^{* * *}$ & $-0.0633^{* * *}$ & $-0.0649^{* * *}$ & $-0.0696^{* * *}$ & $-0.0694^{* * *}$ & $-0.0695^{* * *}$ \\
\hline & $(-4.31)$ & $(-4.37)$ & $(-5.66)$ & $(-5.62)$ & $(-5.63)$ & $(-17.16)$ & $(-17.42)$ & $(-19.29)$ & $(-19.24)$ & $(-19.26)$ \\
\hline \multirow{2}{*}{ AUCHG } & $0.0427^{* * *}$ & $0.0457^{* * *}$ & $0.0473^{* * *}$ & $0.0479^{* * *}$ & $0.0473^{* * *}$ & $0.0600^{* * *}$ & $0.0593^{* * *}$ & $0.0599^{* * *}$ & $0.0598^{* * *}$ & $0.0601^{* * *}$ \\
\hline & -2.59 & -2.71 & -2.86 & -2.9 & -2.86 & -9.86 & -9.66 & -10.09 & -10.07 & -10.11 \\
\hline \multirow{2}{*}{ HIGHTECH } & -0.0006 & 0.0052 & 0.0025 & 0.0042 & 0.0043 & $-0.0141^{* * *}$ & $-0.0112^{* *}$ & $-0.0124^{* * *}$ & $-0.0105^{* *}$ & $-0.0121^{* * *}$ \\
\hline & $(-0.06)$ & -0.45 & -0.22 & -0.37 & -0.38 & $(-3.21)$ & $(-2.53)$ & $(-2.90)$ & $(-2.44)$ & $(-2.83)$ \\
\hline \multirow{2}{*}{ HIGHGROWTH } & $0.0199^{* *}$ & $0.0195^{* *}$ & 0.0136 & 0.0139 & 0.0148 & 0.0029 & 0.0039 & 0.0037 & 0.0035 & 0.0034 \\
\hline & -2.07 & -2.02 & -1.44 & -1.48 & -1.57 & -0.79 & -1.04 & -1.03 & -0.96 & -0.94 \\
\hline \multirow{2}{*}{ HIGHTLIT } & $-0.0423^{* * *}$ & $-0.0503^{* * *}$ & $-0.0411^{* * *}$ & $-0.0447^{* * *}$ & $-0.0434^{* * *}$ & $-0.0277^{* * *}$ & $-0.0304^{* * *}$ & $-0.0316^{* * *}$ & $-0.0329^{* * *}$ & $-0.0316^{* * *}$ \\
\hline & $(-3.61)$ & $(-4.18)$ & $(-3.55)$ & $(-3.83)$ & $(-3.73)$ & $(-6.03)$ & $(-6.54)$ & $(-7.03)$ & $(-7.31)$ & $(-7.02)$ \\
\hline \multirow{2}{*}{ BUSY } & 0.0009 & 0.0017 & 0.0026 & 0.0027 & 0.0032 & $-0.0073^{* *}$ & $-0.0059^{*}$ & $-0.0084^{* * *}$ & $-0.0079^{* *}$ & $-0.0081^{* * *}$ \\
\hline & -0.11 & -0.22 & -0.33 & -0.34 & -0.41 & $(-2.30)$ & $(-1.83)$ & $(-2.69)$ & $(-2.53)$ & $(-2.60)$ \\
\hline \multirow{2}{*}{ ABSACCR } & $0.2560^{* * *}$ & $0.2280^{* * *}$ & 0.0712 & 0.0651 & 0.0726 & $0.1580^{* * *}$ & $0.1720^{* * *}$ & 0.0414 & $0.0457^{*}$ & $0.0459^{*}$ \\
\hline & -3.72 & -3.23 & -1.01 & -0.92 & -1.03 & -5.97 & -6.43 & -1.59 & -1.75 & -1.76 \\
\hline \multirow{2}{*}{ CONSTANT } & $4.227^{* * *}$ & $4.192^{* * *}$ & $4.149^{* * *}$ & $4.138^{* * *}$ & $4.145^{* * *}$ & $4.261^{* * *}$ & $4.258^{* * *}$ & $4.160^{* * *}$ & $4.149^{* * *}$ & $4.158^{* * *}$ \\
\hline & -61.4 & -60 & -60.49 & -60.23 & -60.42 & -160.51 & -158.44 & -156.85 & -156.18 & -156.66 \\
\hline$N$ & 3985 & 3877 & 3751 & 3751 & 3751 & 29183 & 28703 & 27346 & 27346 & 27346 \\
\hline $\operatorname{adj} . R^{2}$ & 0.235 & 0.235 & 0.241 & 0.242 & 0.242 & 0.29 & 0.289 & 0.31 & 0.31 & 0.309 \\
\hline
\end{tabular}

$t$ statistics in parentheses, ${ }^{*} p<0.10,{ }^{* *} p<0.05,{ }^{* * *} p<0.01$ 
Table 5 Panel B Difference Tests (Coefficients)

\begin{tabular}{lcc} 
& \multicolumn{2}{c}{ Suspect } \\
\cline { 2 - 3 } REMCASH & Coeff. Est. & z-stat \\
\cline { 2 - 3 } REMDISC & 0.05 & 1.38 \\
REMPROD & 0.06 & $3.26^{* * *}$ \\
REM1 & 0.07 & $3.91^{* * *}$ \\
REM2 & 0.04 & $4.45^{* * *}$ \\
& 0.04 & $4.3^{* * *}$
\end{tabular}

\begin{tabular}{cc}
\multicolumn{2}{c}{ Non Suspect } \\
\hline Coeff. Est. & z-stat \\
\hline 0 & -0.49 \\
0.02 & $3.51^{* * *}$ \\
0.03 & $6.40^{* * *}$ \\
0.02 & $7.1 * * *$ \\
0.01 & $5.08^{* * *}$
\end{tabular}

\begin{tabular}{cc}
\multicolumn{2}{c}{ Difference } \\
\hline Coeff. Difference & Wald Chi-Square \\
\hline 0.05 & 2.05 \\
0.041 & $4.88^{* * *}$ \\
0.037 & $4.1^{* * *}$ \\
0.021 & $4.55^{* * *}$ \\
0.025 & $7.11^{* * *}$
\end{tabular}


Table 6 Accelerated vs Non-Accelerated (Subsample)

Panel A

\begin{tabular}{|c|c|c|c|c|c|c|c|c|c|c|}
\hline & $\begin{array}{c}\text { Accel- } \\
\text { erated } \\
1\end{array}$ & $\begin{array}{c}\text { Accel- } \\
\text { erated } \\
2 \\
\end{array}$ & $\begin{array}{c}\text { Accel- } \\
\text { erated } \\
3 \\
\end{array}$ & $\begin{array}{c}\text { Accel- } \\
\text { erated } \\
4 \\
\end{array}$ & $\begin{array}{c}\text { Accel- } \\
\text { erated } \\
5 \\
\end{array}$ & $\begin{array}{l}\text { Non- } \\
\text { Accel- } \\
\text { erated } \\
6 \\
\end{array}$ & $\begin{array}{l}\text { Non- } \\
\text { Accel- } \\
\text { erated } \\
7 \\
\end{array}$ & $\begin{array}{l}\text { Non- } \\
\text { Accel- } \\
\text { erated } \\
8 \\
\end{array}$ & $\begin{array}{l}\text { Non- } \\
\text { Accel- } \\
\text { erated } \\
9 \\
\end{array}$ & $\begin{array}{l}\text { Non- } \\
\text { Accel- } \\
\text { erated } \\
10 \\
\end{array}$ \\
\hline REM & $-0.0185^{*}$ & & & & & -0.0055 & & & & \\
\hline CASH & $(-1.82)$ & & & & & $(-1.08)$ & & & & \\
\hline REM & & $0.0686^{* * *}$ & & & & & $0.0122^{* *}$ & & & \\
\hline DISC & & -11.02 & & & & & -2.31 & & & \\
\hline REM & & & $0.0427^{* * *}$ & & & & & $0.0204^{* * *}$ & & \\
\hline PROD & & & -6.49 & & & & & -3.78 & & \\
\hline REM1 & & & & $\begin{array}{c}0.0353^{* * *} \\
-9.78\end{array}$ & & & & & $\begin{array}{c}0.0155^{* * *} \\
-4.85\end{array}$ & \\
\hline REM2 & & & & & $\begin{array}{c}0.0283^{* * *} \\
-8.49\end{array}$ & & & & & $\begin{array}{c}0.0078^{* * *} \\
-2.9\end{array}$ \\
\hline LGTA & $\begin{array}{c}-0.0814^{* * *} \\
(-49.02)\end{array}$ & $\begin{array}{c}-0.0835^{* * *} \\
(-49.16)\end{array}$ & $\begin{array}{c}-0.0806^{* * *} \\
(-47.66)\end{array}$ & $\begin{array}{c}-0.0824^{* * *} \\
(-48.33)\end{array}$ & $\begin{array}{c}-0.0811^{* * *} \\
(-47.94)\end{array}$ & $\begin{array}{c}-0.0156^{* * *} \\
(-5.90)\end{array}$ & $\begin{array}{c}-0.0157^{* * *} \\
(-5.86)\end{array}$ & $\begin{array}{c}-0.0265^{* * *} \\
(-9.90)\end{array}$ & $\begin{array}{c}-0.0271^{* * *} \\
(-10.11)\end{array}$ & $\begin{array}{c}-0.0259^{* * *} \\
(-9.71)\end{array}$ \\
\hline LGSEG & 0.0002 & -0.0015 & -0.0005 & -0.0012 & -0.0011 & $0.0159^{* * *}$ & $0.0147^{* * *}$ & $0.0148^{* * *}$ & $0.0144^{* * *}$ & $0.0148^{* * *}$ \\
\hline MENTS & -0.15 & $(-0.89)$ & $(-0.32)$ & $(-0.74)$ & $(-0.63)$ & -4.21 & -3.87 & -4.03 & -3.93 & -4.04 \\
\hline LGAUDIT & $0.0674^{* * *}$ & $0.0679^{* * *}$ & $0.0656^{* * *}$ & $0.0666^{* * *}$ & $0.0656^{* * *}$ & 0.0024 & 0.0040 & $0.0227^{* * *}$ & $0.0244^{* * *}$ & $0.0226^{* * *}$ \\
\hline $\mathrm{FEE}$ & -24.25 & -24.34 & -23.3 & -23.68 & -23.3 & -0.57 & -0.94 & -5.34 & -5.7 & -5.3 \\
\hline CR & $\begin{array}{c}-0.0042^{* * *} \\
(-5.40)\end{array}$ & $\begin{array}{c}-0.0055^{* * *} \\
(-6.91)\end{array}$ & $\begin{array}{c}-0.0051^{* * *} \\
(-6.35)\end{array}$ & $\begin{array}{c}-0.0054^{* * *} \\
(-6.77)\end{array}$ & $\begin{array}{c}-0.0055^{* * *} \\
(-6.82)\end{array}$ & $\begin{array}{c}-0.0038^{* * *} \\
(-2.63)\end{array}$ & $\begin{array}{c}-0.0038^{* * *} \\
(-2.64)\end{array}$ & $\begin{array}{c}-0.0037^{* * *} \\
(-2.65)\end{array}$ & $\begin{array}{c}-0.0038^{* * *} \\
(-2.70)\end{array}$ & $\begin{array}{c}-0.0038^{* * *} \\
(-2.69)\end{array}$ \\
\hline ROA & $\begin{array}{c}0.0769^{* * *} \\
-4.66\end{array}$ & $\begin{array}{c}0.0682^{* * *} \\
-5.06\end{array}$ & $\begin{array}{c}0.1190^{* * *} \\
-8.45\end{array}$ & $\begin{array}{c}0.1010^{* * *} \\
-7.5\end{array}$ & $\begin{array}{c}0.1260^{* * *} \\
-9.01\end{array}$ & $\begin{array}{c}-0.0026 \\
(-0.27)\end{array}$ & $\begin{array}{l}-0.0025 \\
(-0.29)\end{array}$ & $\begin{array}{c}0.0154^{*} \\
-1.79\end{array}$ & $\begin{array}{c}0.0093 \\
-1.12\end{array}$ & $\begin{array}{c}0.0159^{*} \\
-1.81\end{array}$ \\
\hline LEV & $\begin{array}{l}-0.0048 \\
(-0.68)\end{array}$ & $\begin{array}{c}-0.0080 \\
(-1.13)\end{array}$ & $\begin{array}{c}-0.0058 \\
(-0.81)\end{array}$ & $\begin{array}{c}-0.0059 \\
(-0.83)\end{array}$ & $\begin{array}{c}-0.0069 \\
(-0.96)\end{array}$ & $\begin{array}{c}0.0782^{* * *} \\
-7.48\end{array}$ & $\begin{array}{c}0.0751^{* * *} \\
-7.12\end{array}$ & $\begin{array}{c}0.0618^{* * *} \\
-5.99\end{array}$ & $\begin{array}{c}0.0608^{* * *} \\
-5.89\end{array}$ & $\begin{array}{c}0.0603^{* * *} \\
-5.84\end{array}$ \\
\hline $\begin{array}{l}\text { EAR } \\
\text { GROWTH }\end{array}$ & $\begin{array}{c}-0.0005 \\
(-1.49)\end{array}$ & $\begin{array}{c}-0.0004 \\
(-1.28)\end{array}$ & $\begin{array}{c}-0.0005 \\
(-1.53)\end{array}$ & $\begin{array}{c}-0.0005 \\
(-1.43)\end{array}$ & $\begin{array}{c}-0.0005 \\
(-1.52)\end{array}$ & $\begin{array}{c}-0.0004 \\
(-0.72)\end{array}$ & $\begin{array}{c}-0.0003 \\
(-0.57)\end{array}$ & $\begin{array}{c}-0.0008 \\
(-1.47)\end{array}$ & $\begin{array}{l}-0.0007 \\
(-1.42)\end{array}$ & $\begin{array}{c}-0.0007 \\
(-1.40)\end{array}$ \\
\hline FOROPS & $\begin{array}{c}-0.0299^{* * *} \\
(-8.56)\end{array}$ & $\begin{array}{c}-0.0295^{* * *} \\
(-8.36)\end{array}$ & $\begin{array}{c}-0.0293^{* * *} \\
(-8.20)\end{array}$ & $\begin{array}{c}-0.0289^{* * *} \\
(-8.09)\end{array}$ & $\begin{array}{c}-0.0286^{* * *} \\
(-8.01)\end{array}$ & $\begin{array}{c}-0.0013 \\
(-0.18)\end{array}$ & $\begin{array}{c}-0.0021 \\
(-0.30)\end{array}$ & $\begin{array}{c}-0.0016 \\
(-0.24)\end{array}$ & $\begin{array}{c}-0.0022 \\
(-0.33)\end{array}$ & $\begin{array}{c}-0.0020 \\
(-0.29)\end{array}$ \\
\hline
\end{tabular}


Table 6 Panel A Continued

\begin{tabular}{|c|c|c|c|c|c|c|c|c|c|c|}
\hline & 1 & 2 & 3 & 4 & 5 & 6 & 7 & 8 & 9 & 10 \\
\hline \multirow{2}{*}{ PENSION } & $-0.0132^{* * *}$ & $-0.0129^{* * *}$ & $-0.0122^{* * *}$ & $-0.0129^{* * *}$ & $-0.0128^{* * *}$ & -0.0152 & -0.0169 & $-0.0222^{*}$ & $-0.0229^{*}$ & $-0.0228^{*}$ \\
\hline & $(-3.11)$ & $(-2.99)$ & $(-2.82)$ & $(-2.98)$ & $(-2.96)$ & $(-1.21)$ & $(-1.33)$ & $(-1.81)$ & $(-1.86)$ & $(-1.86)$ \\
\hline \multirow{2}{*}{ GC } & $0.1190^{* * *}$ & $0.1170^{* * *}$ & $0.1150^{* * *}$ & $0.1160^{* * *}$ & $0.1140^{* * *}$ & $0.0781^{* * *}$ & $0.0766^{* * *}$ & $0.0960^{* * *}$ & $0.0945^{* * *}$ & $0.0957^{* * *}$ \\
\hline & -9.36 & -9.16 & -8.91 & -8.96 & -8.84 & -8.89 & -8.65 & -11.21 & -11.03 & -11.17 \\
\hline \multirow{2}{*}{ LOSS } & $0.0542^{* * *}$ & $0.0540^{* * *}$ & $0.0556^{* * *}$ & $0.0552^{* * *}$ & $0.0560^{* * *}$ & $0.0448^{* * *}$ & $0.0455^{* * *}$ & $0.0475^{* * *}$ & $0.0479^{* * *}$ & $0.0484^{* * *}$ \\
\hline & -13.26 & -13.2 & -13.39 & -13.32 & -13.5 & -7.23 & -7.3 & -7.88 & -7.96 & -8.05 \\
\hline \multirow{2}{*}{ EXITEM } & 0.0041 & 0.0007 & 0.0032 & 0.0018 & 0.0019 & $0.0285^{* * *}$ & $0.0264^{* * *}$ & $0.0306^{* * *}$ & $0.0292^{* * *}$ & $0.0303^{* * *}$ \\
\hline & -1.12 & -0.19 & -0.86 & -0.47 & -0.52 & -3.54 & -3.22 & -3.91 & -3.73 & -3.86 \\
\hline \multirow{2}{*}{$\mathrm{ACQ}$} & $-0.0101^{* * *}$ & $-0.0103^{* * *}$ & $-0.0100^{* * *}$ & $-0.00100^{* * *}$ & $-0.00100^{* * *}$ & 0.0129 & 0.0104 & 0.00515 & 0.0046 & 0.0049 \\
\hline & $(-2.83)$ & $(-2.86)$ & $(-2.73)$ & $(-2.68)$ & $(-2.68)$ & -1.35 & -1.07 & -0.54 & -0.48 & -0.52 \\
\hline \multirow{2}{*}{ BIG4 } & $-0.0490^{* * *}$ & $-0.0503^{* * *}$ & $-0.0510^{* * *}$ & $-0.0508^{* * *}$ & $-0.0510^{* * *}$ & $-0.0744^{* * *}$ & $-0.0764^{* * *}$ & $-0.1090^{* * *}$ & $-0.1090^{* * *}$ & $-0.1090^{* * *}$ \\
\hline & $(-15.40)$ & $(-15.67)$ & $(-15.73)$ & $(-15.68)$ & $(-15.73)$ & $(-8.46)$ & $(-8.61)$ & $(-12.27)$ & $(-12.28)$ & $(-12.26)$ \\
\hline \multirow{2}{*}{ AUCHG } & $0.0732^{* * *}$ & $0.0730^{* * *}$ & $0.0727^{* * *}$ & $0.0724^{* * *}$ & $0.0726^{* * *}$ & $0.0232^{* *}$ & $0.0237^{* *}$ & $0.0233^{* *}$ & $0.0229^{* *}$ & $0.0234^{* *}$ \\
\hline & -10.98 & -10.86 & -10.67 & -10.63 & -10.65 & -2.44 & -2.46 & -2.56 & -2.51 & -2.56 \\
\hline HIGH & $-0.0094^{* *}$ & -0.0006 & -0.0028 & 0.0003 & -0.0006 & -0.0120 & -0.0101 & $-0.0167^{* *}$ & $-0.0145^{*}$ & $-0.0164^{* *}$ \\
\hline TECH & $(-2.19)$ & $(-0.13)$ & $(-0.64)$ & -0.08 & $(-0.13)$ & $(-1.53)$ & $(-1.27)$ & $(-2.21)$ & $(-1.90)$ & $(-2.16)$ \\
\hline HIGH & $0.0089^{* *}$ & $0.0098^{* * *}$ & $0.0100^{* * *}$ & $0.0100^{* * *}$ & $0.0107^{* * *}$ & -0.0069 & -0.0056 & -0.0081 & -0.0081 & -0.0087 \\
\hline GROWTH & -2.4 & -2.64 & -2.67 & -2.67 & -2.84 & $(-1.08)$ & $(-0.88)$ & $(-1.30)$ & $(-1.30)$ & $(-1.40)$ \\
\hline \multirow{2}{*}{ HIGHTLIT } & $-0.0351^{* * *}$ & $-0.0430^{* * *}$ & $-0.0385^{* * *}$ & $-0.0417^{* * *}$ & $-0.0406^{* * *}$ & $-0.0185^{* *}$ & $-0.0200^{* *}$ & $-0.0225^{* * *}$ & $-0.0236^{* * *}$ & $-0.0222^{* * *}$ \\
\hline & $(-7.81)$ & $(-9.39)$ & $(-8.38)$ & $(-9.05)$ & $(-8.82)$ & $(-2.26)$ & $(-2.43)$ & $(-2.84)$ & $(-2.97)$ & $(-2.81)$ \\
\hline \multirow{2}{*}{ BUSY } & -0.0014 & 0.0014 & 0.0007 & 0.0009 & 0.0010 & -0.0075 & -0.0083 & $-0.0142^{* * *}$ & $-0.0137^{* * *}$ & $-0.0140^{* * *}$ \\
\hline & $(-0.45)$ & -0.44 & -0.21 & -0.27 & -0.32 & $(-1.38)$ & $(-1.51)$ & $(-2.69)$ & $(-2.61)$ & $(-2.66)$ \\
\hline ABS & 0.0332 & 0.0414 & 0.0428 & 0.0411 & $0.0490^{*}$ & $0.2580^{* * *}$ & $0.2670^{* * *}$ & 0.0515 & 0.0611 & 0.0565 \\
\hline ACCR & -1.27 & -1.57 & -1.61 & -1.55 & -1.84 & -5.5 & -5.64 & -1.11 & -1.32 & -1.22 \\
\hline \multirow{2}{*}{ CONS } & $3.771^{* * *}$ & $3.786^{* * *}$ & $3.792^{* * *}$ & $3.793^{* * *}$ & $3.799^{* * *}$ & $4.327^{* * *}$ & $4.312^{* * *}$ & $4.152^{* * *}$ & $4.134^{* * *}$ & $4.151^{* * *}$ \\
\hline & -125.02 & -124.98 & -123.75 & -123.96 & -123.97 & -99.14 & -97.05 & -93.82 & -92.78 & -93.54 \\
\hline$N$ & 20747 & 20332 & 20011 & 20011 & 20011 & 12421 & 12248 & 11086 & 11086 & 11086 \\
\hline $\operatorname{adj} . R^{2}$ & 0.213 & 0.214 & 0.212 & 0.214 & 0.213 & 0.098 & 0.098 & 0.128 & 0.128 & 0.127 \\
\hline
\end{tabular}

$t$ statistics in parentheses, ${ }^{*} p<0.10,{ }^{* *} p<0.05,{ }^{* * *} p<0.01$ 
Table 6 Panel B Difference Tests (Coefficients)

\begin{tabular}{lcc} 
& \multicolumn{2}{c}{ Accelerated } \\
\cline { 2 - 3 } & Coeff. Est. & Z-stat \\
\cline { 2 - 3 } REMCASH & -0.02 & -1.64 \\
REMDISC & 0.06 & $10.25^{* * *}$ \\
REMPROD & 0.04 & $6.46^{* * *}$ \\
REM1 & 0.03 & $9.31^{* * *}$ \\
REM2 & 0.02 & $7.72^{* * *}$
\end{tabular}

\begin{tabular}{cc}
\multicolumn{2}{c}{ Non-Accelerated } \\
\hline Coeff. Est. & Z-stat \\
\hline 0 & -0.99 \\
0.01 & $2.06^{* *}$ \\
0.02 & $3.36^{* * *}$ \\
0.01 & $4.22^{* * *}$ \\
0 & $2.51^{* *}$
\end{tabular}

\begin{tabular}{cc}
\multicolumn{2}{c}{ Difference } \\
\hline Coeff. & Wald Chi- \\
Difference & Square \\
\hline-0.02 & 1.07 \\
0.05 & $39.65^{* * *}$ \\
0.02 & $6.16^{* *}$ \\
0.02 & $14.13^{* * *}$ \\
0.02 & $18.40^{* * *}$
\end{tabular}


Table 7 REM and Audit Report Lags for Suspect Firms: Accelerated vs Non-Accelerated

\begin{tabular}{|c|c|c|c|c|c|c|c|c|c|c|}
\hline & $\begin{array}{c}\text { Suspect } \\
\text { Accel } \\
1 \\
\end{array}$ & $\begin{array}{c}\text { Suspect } \\
\text { Accel } \\
2 \\
\end{array}$ & $\begin{array}{c}\text { Suspect } \\
\text { Accel } \\
3 \\
\end{array}$ & $\begin{array}{c}\text { Suspect } \\
\text { Accel } \\
4 \\
\end{array}$ & $\begin{array}{c}\text { Suspect } \\
\text { Accel } \\
5 \\
\end{array}$ & $\begin{array}{c}\text { Suspect } \\
\text { Non Accel } \\
6\end{array}$ & $\begin{array}{c}\text { Suspect } \\
\text { Non Accel } \\
7 \\
\end{array}$ & $\begin{array}{c}\text { Suspect } \\
\text { Non Accel } \\
8 \\
\end{array}$ & $\begin{array}{c}\text { Suspect } \\
\text { Non Accel } \\
9 \\
\end{array}$ & $\begin{array}{c}\text { Suspect } \\
\text { Non Accel } \\
10 \\
\end{array}$ \\
\hline REM & -0.0227 & & & & & -0.00582 & & & & \\
\hline CASH & $(-0.57)$ & & & & & $(-1.13)$ & & & & \\
\hline REM & & $0.0604^{* * *}$ & & & & & $0.0107^{* *}$ & & & \\
\hline DISC & & -3.02 & & & & & -1.99 & & & \\
\hline REM & & & 0.0342 & & & & & $0.0191^{* * *}$ & & \\
\hline PROD & & & -1.6 & & & & & -3.49 & & \\
\hline \multirow{2}{*}{ REM1 } & & & & $0.0293^{* * *}$ & & & & & $0.0144^{* * *}$ & \\
\hline & & & & -2.61 & & & & & -4.44 & \\
\hline \multirow{2}{*}{ REM2 } & & & & & $0.0229^{* *}$ & & & & & $0.00676^{* *}$ \\
\hline & & & & & -2.22 & & & & & -2.49 \\
\hline LGTA & $\begin{array}{c}-0.0739^{* * *} \\
(-17.66)\end{array}$ & $\begin{array}{c}-0.0747^{* * *} \\
(-17.16)\end{array}$ & $\begin{array}{c}-0.0727^{* * *} \\
(-16.80)\end{array}$ & $\begin{array}{c}-0.0740^{* * *} \\
(-16.93)\end{array}$ & $\begin{array}{c}-0.0732^{* * *} \\
(-16.88)\end{array}$ & $\begin{array}{c}-0.0144^{* * *} \\
(-5.16)\end{array}$ & $\begin{array}{c}-0.0143^{* * *} \\
(-5.09)\end{array}$ & $\begin{array}{c}-0.0253^{* * *} \\
(-8.98)\end{array}$ & $\begin{array}{c}-0.0258^{* * *} \\
(-9.15)\end{array}$ & $\begin{array}{c}-0.0246^{* * *} \\
(-8.78)\end{array}$ \\
\hline LGSEG & -0.0046 & -0.0051 & -0.0047 & -0.0051 & -0.0049 & $0.0162^{* * *}$ & $0.0155^{* * *}$ & $0.0165^{* * *}$ & $0.0161^{* * *}$ & $0.0165^{* * *}$ \\
\hline MENTS & $(-1.18)$ & $(-1.28)$ & $(-1.15)$ & $(-1.26)$ & $(-1.21)$ & -4.06 & -3.85 & -4.24 & -4.16 & -4.26 \\
\hline LGAUDIT & $0.0502^{* * *}$ & $0.0501^{* * *}$ & $0.0488^{* * *}$ & $0.0499^{* * *}$ & $0.0490^{* * *}$ & 0.0005 & 0.0019 & $0.0203^{* * *}$ & $0.0220^{* * *}$ & $0.0201^{* * *}$ \\
\hline FEE & -7.39 & -7.3 & -7.06 & -7.2 & -7.09 & -0.12 & -0.42 & -4.6 & -4.93 & -4.54 \\
\hline CR & $\begin{array}{c}-0.0009 \\
(-0.47)\end{array}$ & $\begin{array}{c}-0.0024 \\
(-1.24)\end{array}$ & $\begin{array}{c}-0.0023 \\
(-1.13)\end{array}$ & $\begin{array}{c}-0.0025 \\
(-1.23)\end{array}$ & $\begin{array}{c}-0.0024 \\
(-1.21)\end{array}$ & $\begin{array}{c}-0.0046^{* * *} \\
(-3.00)\end{array}$ & $\begin{array}{c}-0.0047^{* * *} \\
(-3.05)\end{array}$ & $\begin{array}{c}-0.0044^{* * *} \\
(-2.95)\end{array}$ & $\begin{array}{c}-0.0044^{* * *} \\
(-2.97)\end{array}$ & $\begin{array}{c}-0.0044^{* * *} \\
(-2.97)\end{array}$ \\
\hline ROA & $\begin{array}{c}-0.4570^{* * *} \\
(-4.24)\end{array}$ & $\begin{array}{c}-0.4500^{* * *} \\
(-4.52)\end{array}$ & $\begin{array}{c}-0.4060^{* * *} \\
(-3.93)\end{array}$ & $\begin{array}{c}-0.4200^{* * *} \\
(-4.15)\end{array}$ & $\begin{array}{c}-0.3980^{* * *} \\
(-3.88)\end{array}$ & $\begin{array}{c}-0.0032 \\
(-0.32)\end{array}$ & $\begin{array}{c}-0.0026 \\
(-0.29)\end{array}$ & $\begin{array}{c}0.0149^{*} \\
-1.7\end{array}$ & $\begin{array}{c}0.0092 \\
-1.08\end{array}$ & $\begin{array}{c}0.0148^{*} \\
-1.66\end{array}$ \\
\hline LEV & $\begin{array}{c}0.0005 \\
-0.02\end{array}$ & $\begin{array}{c}-0.0071 \\
(-0.35)\end{array}$ & $\begin{array}{c}-0.0073 \\
(-0.36)\end{array}$ & $\begin{array}{c}-0.0080 \\
(-0.40)\end{array}$ & $\begin{array}{c}-0.0084 \\
(-0.42)\end{array}$ & $\begin{array}{c}0.0751^{* * *} \\
-6.88\end{array}$ & $\begin{array}{c}0.0717^{* * *} \\
-6.52\end{array}$ & $\begin{array}{c}0.0611^{* * *} \\
-5.68\end{array}$ & $\begin{array}{c}0.0602^{* * *} \\
-5.6\end{array}$ & $\begin{array}{c}0.0597^{* * *} \\
-5.55\end{array}$ \\
\hline $\begin{array}{l}\text { EAR } \\
\text { GROWTH }\end{array}$ & $\begin{array}{c}-0.0047 \\
(-1.49)\end{array}$ & $\begin{array}{c}-0.0050 \\
(-1.58)\end{array}$ & $\begin{array}{c}-0.0053^{*} \\
(-1.68)\end{array}$ & $\begin{array}{c}-0.0054^{*} \\
(-1.70)\end{array}$ & $\begin{array}{c}-0.0054^{*} \\
(-1.71)\end{array}$ & $\begin{array}{c}-0.0004 \\
(-0.65)\end{array}$ & $\begin{array}{c}-0.0003 \\
(-0.52)\end{array}$ & $\begin{array}{l}-0.0007 \\
(-1.35)\end{array}$ & $\begin{array}{c}-0.0007 \\
(-1.30)\end{array}$ & $\begin{array}{c}-0.0007 \\
(-1.29)\end{array}$ \\
\hline FOROPS & $\begin{array}{c}-0.0473^{* * *} \\
(-5.33)\end{array}$ & $\begin{array}{c}-0.0479^{* * *} \\
(-5.29)\end{array}$ & $\begin{array}{c}-0.0498^{* * *} \\
(-5.41)\end{array}$ & $\begin{array}{c}-0.0492^{* * *} \\
(-5.35)\end{array}$ & $\begin{array}{c}-0.0494^{* * *} \\
(-5.37)\end{array}$ & $\begin{array}{c}-0.00333 \\
(-0.46)\end{array}$ & $\begin{array}{c}-0.00341 \\
(-0.46)\end{array}$ & $\begin{array}{c}-0.00355 \\
(-0.50)\end{array}$ & $\begin{array}{c}-0.00409 \\
(-0.57)\end{array}$ & $\begin{array}{c}-0.00391 \\
(-0.55)\end{array}$ \\
\hline
\end{tabular}




\section{Table 7 Continued}

\begin{tabular}{|c|c|c|c|c|c|c|c|c|c|c|}
\hline 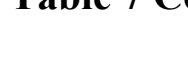 & 1 & 2 & 3 & 4 & 5 & 6 & 7 & 8 & 9 & 10 \\
\hline \multirow{2}{*}{ PENSION } & -0.0019 & -0.0012 & -0.0009 & -0.0015 & -0.0013 & -0.0081 & -0.0116 & -0.0167 & -0.0172 & -0.0172 \\
\hline & $(-0.20)$ & $(-0.12)$ & $(-0.09)$ & $(-0.15)$ & $(-0.13)$ & $(-0.59)$ & $(-0.85)$ & $(-1.26)$ & $(-1.30)$ & $(-1.29)$ \\
\hline \multirow{2}{*}{ GC } & 0.0855 & 0.0758 & 0.0830 & 0.0792 & 0.0802 & $0.0794^{* * *}$ & $0.0782^{* * *}$ & $0.0963^{* * *}$ & $0.0949^{* * *}$ & $0.0962^{* * *}$ \\
\hline & -1.23 & -1.09 & -1.18 & -1.13 & -1.14 & -8.87 & -8.65 & -11.01 & -10.85 & -10.99 \\
\hline \multirow{2}{*}{ LOSS } & -0.0179 & -0.0147 & -0.0175 & -0.0162 & -0.0166 & $0.0483^{* * *}$ & $0.0486^{* * *}$ & $0.0506^{* * *}$ & $0.0509^{* * *}$ & $0.0515^{* * *}$ \\
\hline & $(-1.03)$ & $(-0.84)$ & $(-0.96)$ & $(-0.89)$ & $(-0.92)$ & -7.38 & -7.39 & -7.95 & -8 & -8.1 \\
\hline \multirow{2}{*}{ EXITEM } & -0.00211 & -0.0032 & -0.0016 & -0.0026 & -0.0023 & $0.0282^{* * *}$ & $0.0256^{* * *}$ & $0.0290^{* * *}$ & $0.0277^{* * *}$ & $0.0288^{* * *}$ \\
\hline & $(-0.23)$ & $(-0.34)$ & $(-0.17)$ & $(-0.28)$ & $(-0.24)$ & -3.35 & -3 & -3.53 & -3.37 & -3.5 \\
\hline \multirow{2}{*}{$\mathrm{ACQ}$} & $-0.0183^{* *}$ & $-0.0216^{* *}$ & $-0.0197^{* *}$ & $-0.0199^{* *}$ & $-0.0197^{* *}$ & 0.0125 & 0.0112 & 0.0067 & 0.0061 & 0.0065 \\
\hline & $(-2.19)$ & $(-2.54)$ & $(-2.29)$ & $(-2.31)$ & $(-2.29)$ & -1.24 & -1.1 & -0.67 & -0.61 & -0.65 \\
\hline \multirow{2}{*}{ BIG4 } & $-0.0306^{* * *}$ & $-0.0332^{* * *}$ & $-0.0336^{* * *}$ & $-0.0335^{* * *}$ & $-0.0337^{* * *}$ & $-0.0755^{* * *}$ & $-0.0774^{* * *}$ & $-0.1050^{* * *}$ & $-0.1060^{* * *}$ & $-0.1050^{* * *}$ \\
\hline & $(-3.78)$ & $(-4.03)$ & $(-4.02)$ & $(-4.01)$ & $(-4.03)$ & $(-8.14)$ & $(-8.30)$ & $(-11.27)$ & $(-11.29)$ & $(-11.26)$ \\
\hline \multirow{2}{*}{ AUCHG } & $0.0497^{* * *}$ & $0.0526^{* * *}$ & $0.0526^{* * *}$ & $0.0528^{* * *}$ & $0.0528^{* * *}$ & $0.0239^{* *}$ & $0.0238^{* *}$ & $0.0237^{* *}$ & $0.0233^{* *}$ & $0.0238^{* *}$ \\
\hline & -2.73 & -2.82 & -2.77 & -2.78 & -2.78 & -2.4 & -2.36 & -2.48 & -2.44 & -2.49 \\
\hline HIGH & -0.0153 & -0.0086 & -0.0104 & -0.0083 & -0.0087 & $-0.0144^{*}$ & -0.0129 & $-0.0195^{* *}$ & $-0.0173^{* *}$ & $-0.0193^{* *}$ \\
\hline TECH & $(-1.36)$ & $(-0.76)$ & $(-0.90)$ & $(-0.72)$ & $(-0.76)$ & $(-1.77)$ & $(-1.57)$ & $(-2.48)$ & $(-2.19)$ & $(-2.45)$ \\
\hline HIGH & $0.0190^{* *}$ & $0.0188^{* *}$ & $0.0178^{*}$ & $0.0181^{*}$ & $0.0187^{*}$ & -0.0082 & -0.0072 & -0.0085 & -0.0085 & -0.0092 \\
\hline GROWTH & -2.03 & -2 & -1.87 & -1.9 & -1.95 & $(-1.24)$ & $(-1.08)$ & $(-1.31)$ & $(-1.31)$ & $(-1.42)$ \\
\hline \multirow{2}{*}{ HIGHLIT } & $-0.0238^{* *}$ & $-0.0302^{* *}$ & $-0.0253^{* *}$ & $-0.0287^{* *}$ & $-0.0272^{* *}$ & -0.0137 & $-0.0151^{*}$ & $-0.0184^{* *}$ & $-0.0194^{* *}$ & $-0.0181^{* *}$ \\
\hline & $(-2.08)$ & $(-2.54)$ & $(-2.15)$ & $(-2.41)$ & $(-2.30)$ & $(-1.62)$ & $(-1.77)$ & $(-2.24)$ & $(-2.34)$ & $(-2.19)$ \\
\hline \multirow{2}{*}{ BUSY } & 0.0039 & 0.0072 & 0.0075 & 0.0077 & 0.0080 & -0.0076 & -0.0084 & $-0.0144^{* * *}$ & $-0.0139^{* *}$ & $-0.0142^{* * *}$ \\
\hline & -0.49 & -0.89 & -0.92 & -0.95 & -0.99 & $(-1.34)$ & $(-1.46)$ & $(-2.61)$ & $(-2.53)$ & $(-2.58)$ \\
\hline $\mathrm{ABS}$ & 0.0497 & 0.0405 & 0.0603 & 0.0527 & 0.0603 & $0.2330^{* * *}$ & $0.2450^{* * *}$ & 0.0407 & 0.0501 & 0.0456 \\
\hline ACCR & -0.71 & -0.56 & -0.82 & -0.72 & -0.82 & -4.72 & -4.91 & -0.84 & -1.03 & -0.94 \\
\hline \multirow{2}{*}{ CONS } & $3.988^{* * *}$ & $4.004^{* * *}$ & $4.005^{* * *}$ & $4.002^{* * *}$ & $4.007^{* * *}$ & $4.349^{* * *}$ & $4.335^{* * *}$ & $4.176^{* * *}$ & $4.159^{* * *}$ & $4.176^{* * *}$ \\
\hline & -54.68 & -54.38 & -53.8 & -53.8 & -53.85 & -95.88 & -93.95 & -90.72 & -89.74 & -90.47 \\
\hline$N$ & 2994 & 2913 & 2864 & 2864 & 2864 & 11430 & 11284 & 10199 & 10199 & 10199 \\
\hline adj. $R^{2}$ & 0.203 & 0.201 & 0.2 & 0.201 & 0.2 & 0.1 & 0.1 & 0.13 & 0.13 & 0.129 \\
\hline
\end{tabular}

$t$ statistics in parentheses, ${ }^{*} p<0.10,{ }^{* *} p<0.05,{ }^{* * *} p<0.01$ 
Table 8 Short and Long Audit Report Lag

\begin{tabular}{|c|c|c|c|c|c|c|c|c|c|c|}
\hline & $\begin{array}{l}\text { Short } \\
\text { REM } \\
\text { CASH }\end{array}$ & $\begin{array}{l}\text { Short } \\
\text { REM } \\
\text { DISC }\end{array}$ & $\begin{array}{c}\text { Short } \\
\text { REM } \\
\text { PROD }\end{array}$ & $\begin{array}{l}\text { Short } \\
\text { REM1 }\end{array}$ & $\begin{array}{l}\text { Short } \\
\text { REM2 }\end{array}$ & $\begin{array}{l}\text { Long } \\
\text { REM } \\
\text { CASH }\end{array}$ & $\begin{array}{l}\text { Long } \\
\text { REM } \\
\text { DISC } \\
\end{array}$ & $\begin{array}{c}\text { Long } \\
\text { REM } \\
\text { PROD }\end{array}$ & $\begin{array}{l}\text { Long } \\
\text { REM1 }\end{array}$ & $\begin{array}{l}\text { Long } \\
\text { REM2 }\end{array}$ \\
\hline LAG & 0.0098 & -0.0407 & -0.0238 & -0.0661 & -0.054 & -0.0007 & -0.0003 & $-0.0089^{* *}$ & $-0.0144^{* *}$ & $-0.0156^{* *}$ \\
\hline DUMMY & -0.36 & $(-1.35)$ & $(-0.81)$ & $(-1.30)$ & $(-0.92)$ & $(-0.20)$ & $(-0.06)$ & $(-2.31)$ & $(-2.17)$ & $(-2.03)$ \\
\hline LGTA & $\begin{array}{c}-0.0281^{* * *} \\
(-14.36)\end{array}$ & $\begin{array}{c}0.0592^{* * *} \\
-27.69\end{array}$ & $\begin{array}{c}0.0353^{* * *} \\
-17.05\end{array}$ & $\begin{array}{c}0.0964^{* * *} \\
-26.94\end{array}$ & $\begin{array}{c}0.0656^{* * *} \\
-15.83\end{array}$ & $\begin{array}{c}-0.0281^{* * *} \\
(-14.35)\end{array}$ & $\begin{array}{c}0.0591^{* * *} \\
-27.66\end{array}$ & $\begin{array}{c}0.0353^{* * *} \\
-17.09\end{array}$ & $\begin{array}{c}0.0964^{* * *} \\
-26.96\end{array}$ & $\begin{array}{c}0.0657^{* * *} \\
-15.85\end{array}$ \\
\hline LGSEG & -0.0012 & $0.0285^{* * *}$ & $0.0192^{* * *}$ & $0.0473^{* * *}$ & $0.0479^{* * *}$ & -0.0012 & $0.0285^{* * *}$ & $0.0191^{* * *}$ & $0.0473^{* * *}$ & $0.0478^{* * *}$ \\
\hline MENTS & $(-0.71)$ & -11.54 & -8.19 & -11.69 & -10.21 & $(-0.72)$ & -11.56 & -8.17 & -11.68 & -10.19 \\
\hline LGAUDIT & $0.0233^{* * *}$ & $-0.0726^{* * *}$ & $-0.0321^{* * *}$ & $-0.1090^{* * *}$ & $-0.0808^{* * *}$ & $0.0232^{* * *}$ & $-0.0724^{* * *}$ & $-0.0319^{* * *}$ & $-0.1090^{* * *}$ & $-0.0804^{* * *}$ \\
\hline FEE & -7.31 & $(-20.99)$ & $(-9.55)$ & $(-18.80)$ & $(-11.98)$ & -7.31 & $(-20.95)$ & $(-9.49)$ & $(-18.73)$ & $(-11.92)$ \\
\hline $\mathrm{CR}$ & $0.0084^{* * *}$ & $0.0083^{* * *}$ & $0.0045^{* * *}$ & $0.0132^{* * *}$ & $0.0205^{* * *}$ & $0.0084^{* * *}$ & $0.0083^{* * *}$ & $0.0049^{* * *}$ & $0.0132^{* * *}$ & $0.0204^{* * *}$ \\
\hline & -8.48 & -7.66 & -4.75 & -7.36 & -9.82 & -8.48 & -7.65 & -4.71 & -7.32 & -9.78 \\
\hline $\mathrm{ROA}$ & $\begin{array}{l}-0.9720^{* * *} \\
(-115.89)\end{array}$ & $\begin{array}{c}0.2740^{* * *} \\
-30.1\end{array}$ & $\begin{array}{c}-0.3860^{* * *} \\
(-43.30)\end{array}$ & $\begin{array}{c}-0.1170^{* * *} \\
(-7.59)\end{array}$ & $\begin{array}{c}-1.0830^{* * *} \\
(-60.63)\end{array}$ & $\begin{array}{l}-0.9720^{* * *} \\
(-115.89)\end{array}$ & $\begin{array}{c}0.2740^{* * *} \\
-30.1\end{array}$ & $\begin{array}{c}-0.3860^{* * *} \\
(-43.31)\end{array}$ & $\begin{array}{c}-0.1170^{* * *} \\
(-7.59)\end{array}$ & $\begin{array}{c}-1.0830^{* * *} \\
(-60.64)\end{array}$ \\
\hline LEV & $\begin{array}{c}0.0327^{* * *} \\
-4.08\end{array}$ & $\begin{array}{c}0.0223^{* *} \\
-2.56\end{array}$ & $\begin{array}{c}-0.0368^{* * *} \\
(-4.38)\end{array}$ & $\begin{array}{c}-0.0081 \\
(-0.56)\end{array}$ & $\begin{array}{c}0.0315^{*} \\
-1.87\end{array}$ & $\begin{array}{c}0.0326^{* * *} \\
-4.06\end{array}$ & $\begin{array}{c}0.0224^{* *} \\
-2.56\end{array}$ & $\begin{array}{c}-0.0375^{* * *} \\
(-4.46)\end{array}$ & $\begin{array}{c}-0.0092 \\
(-0.63)\end{array}$ & $\begin{array}{c}0.0303^{*} \\
-1.8\end{array}$ \\
\hline EAR & $0.0007^{*}$ & $-0.0012^{* * *}$ & $0.0015^{* * *}$ & 0.0004 & 0.0012 & $0.0007^{*}$ & $-0.0012^{* * *}$ & $0.0014^{* * *}$ & 0.0004 & 0.0012 \\
\hline GROWTH & -1.66 & $(-2.69)$ & -3.39 & -0.49 & -1.4 & -1.66 & $(-2.69)$ & -3.38 & -0.47 & -1.38 \\
\hline FOROPS & $\begin{array}{c}-0.0295^{* * *} \\
(-6.48)\end{array}$ & $\begin{array}{c}0.0061 \\
-1.23\end{array}$ & $\begin{array}{c}-0.0352^{* * *} \\
(-7.43)\end{array}$ & $\begin{array}{c}-0.0262^{* * *} \\
(-3.20)\end{array}$ & $\begin{array}{c}-0.0564^{* * *} \\
(-5.94)\end{array}$ & $\begin{array}{c}-0.0295^{* * *} \\
(-6.47)\end{array}$ & $\begin{array}{c}0.0061 \\
-1.22\end{array}$ & $\begin{array}{c}-0.0351^{* * *} \\
(-7.42)\end{array}$ & $\begin{array}{c}-0.0261^{* * *} \\
(-3.19)\end{array}$ & $\begin{array}{c}-0.0563^{* * *} \\
(-5.93)\end{array}$ \\
\hline PENSION & $\begin{array}{c}0.0155^{* *} \\
-2.48\end{array}$ & $\begin{array}{c}0.0276^{* * *} \\
-4.07\end{array}$ & $\begin{array}{c}0.0197^{* * *} \\
-3.07\end{array}$ & $\begin{array}{c}0.0456^{* * *} \\
-4.12\end{array}$ & $\begin{array}{c}0.0608^{* * *} \\
-4.74\end{array}$ & $\begin{array}{c}0.0155^{\text {** }} \\
-2.49\end{array}$ & $\begin{array}{c}0.0276^{* * *} \\
-4.07\end{array}$ & $\begin{array}{c}0.0199^{* * *} \\
-3.1\end{array}$ & $\begin{array}{c}0.0459^{* * *} \\
-4.14\end{array}$ & $\begin{array}{c}0.0611^{* * *} \\
-4.76\end{array}$ \\
\hline GC & $\begin{array}{c}0.0213^{* *} \\
-2.44\end{array}$ & $\begin{array}{c}0.1240^{* * *} \\
-13.11\end{array}$ & $\begin{array}{c}0.0084 \\
-0.91\end{array}$ & $\begin{array}{c}0.1250^{* * *} \\
-7.83\end{array}$ & $\begin{array}{c}0.1350^{* * *} \\
-7.3\end{array}$ & $\begin{array}{c}0.0213^{* *} \\
-2.43\end{array}$ & $\begin{array}{c}0.1240^{* * *} \\
-13.1\end{array}$ & $\begin{array}{c}0.0076 \\
-0.83\end{array}$ & $\begin{array}{c}0.1230^{* * *} \\
-7.75\end{array}$ & $\begin{array}{c}0.1330^{* * *} \\
-7.23\end{array}$ \\
\hline LOSS & $\begin{array}{c}-0.0365^{* * *} \\
(-8.00)\end{array}$ & $\begin{array}{c}-0.0253^{* * *} \\
(-5.11)\end{array}$ & $\begin{array}{c}0.0349^{* * *} \\
-7.38\end{array}$ & $\begin{array}{c}0.0143^{*} \\
-1.75\end{array}$ & $\begin{array}{c}-0.0256^{* * *} \\
(-2.70)\end{array}$ & $\begin{array}{c}-0.0365^{* * *} \\
(-8.00)\end{array}$ & $\begin{array}{c}-0.0253^{* * *} \\
(-5.10)\end{array}$ & $\begin{array}{c}0.0347^{* * *} \\
-7.34\end{array}$ & $\begin{array}{c}0.0140^{*} \\
-1.71\end{array}$ & $\begin{array}{c}-0.0259^{* * *} \\
(-2.73)\end{array}$ \\
\hline
\end{tabular}


Table 8 Continued

\begin{tabular}{|c|c|c|c|c|c|c|c|c|c|c|}
\hline \multirow{2}{*}{ EXITEM } & 0.0074 & $0.0656^{* * *}$ & $0.0270^{* * *}$ & $0.0914^{* * *}$ & $0.0989^{* * *}$ & 0.0074 & $0.0657^{* * *}$ & $0.0270^{* * *}$ & $0.0914^{* * *}$ & $0.0990^{* * *}$ \\
\hline & -1.49 & -12.08 & -5.24 & -10.26 & -9.58 & -1.49 & -12.09 & -5.25 & -10.27 & -9.59 \\
\hline \multirow{2}{*}{ ACQ } & 0.0030 & 0.0041 & -0.0026 & 0.0030 & 0.0021 & 0.0030 & 0.0040 & -0.0024 & 0.0029 & 0.0024 \\
\hline & -0.58 & -0.73 & $(-0.48)$ & -0.28 & -0.2 & -0.58 & -0.72 & $(-0.45)$ & -0.31 & -0.22 \\
\hline \multirow{2}{*}{ BIG4 } & 0.0039 & $-0.0140^{* * *}$ & 0.0004 & -0.0089 & -0.0051 & 0.0039 & $-0.0142^{* * *}$ & 0.0000 & -0.0096 & -0.0057 \\
\hline & -0.85 & $(-2.80)$ & -0.08 & $(-1.09)$ & $(-0.53)$ & -0.86 & $(-2.85)$ & -0.01 & $(-1.17)$ & $(-0.60)$ \\
\hline \multirow{2}{*}{ AUCHG } & 0.0005 & 0.0131 & $0.0166^{* *}$ & $0.0293^{* *}$ & $0.0273^{*}$ & 0.0005 & 0.0131 & $0.0162^{* *}$ & $0.0287^{* *}$ & $0.0266^{*}$ \\
\hline & -0.06 & -1.57 & -2.09 & -2.14 & -1.72 & -0.06 & -1.56 & -2.04 & -2.09 & -1.67 \\
\hline HIGH & -0.0061 & $-0.1350^{* * *}$ & $-0.0812^{* * *}$ & $-0.2110^{* * *}$ & $-0.2140^{* * *}$ & -0.0061 & $-0.1350^{* * *}$ & $-0.0812^{* * *}$ & $-0.2110^{* * *}$ & $-0.2140^{* * *}$ \\
\hline $\mathrm{TECH}$ & $(-1.10)$ & $(-22.63)$ & $(-14.37)$ & $(-21.59)$ & $(-18.87)$ & $(-1.10)$ & $(-22.64)$ & $(-14.38)$ & $(-21.61)$ & $(-18.88)$ \\
\hline HIGH & $-0.0297^{* * *}$ & $-0.0132^{* * *}$ & $-0.0415^{* * *}$ & $-0.0519^{* * *}$ & $-0.0813^{* * *}$ & $-0.0297^{* * *}$ & $-0.0133^{* * *}$ & $-0.0418^{* * *}$ & $-0.0525^{* * *}$ & $-0.0819^{* * *}$ \\
\hline GROWTH & $(-6.43)$ & $(-2.64)$ & $(-8.66)$ & $(-6.27)$ & $(-8.46)$ & $(-6.43)$ & $(-2.65)$ & $(-8.72)$ & $(-6.34)$ & $(-8.52)$ \\
\hline $\mathrm{HIGH}$ & 0.0094 & $0.1050^{* * *}$ & $0.0774^{* * *}$ & $0.1840^{* * *}$ & $0.1880^{* * *}$ & 0.0094 & $0.1050^{* * *}$ & $0.0774^{* * *}$ & $0.1840^{* * *}$ & $0.1880^{* * *}$ \\
\hline LIT & -1.63 & -16.81 & -13.07 & -17.92 & -15.87 & -1.64 & -16.8 & -13.07 & -17.92 & -15.87 \\
\hline \multirow{2}{*}{ BUSY } & 0.0046 & $-0.0219^{* * *}$ & 0.0044 & $-0.0150^{* *}$ & -0.0089 & 0.0045 & $-0.0217^{* * *}$ & 0.0048 & $-0.0142^{* *}$ & -0.0080 \\
\hline & -1.15 & $(-5.09)$ & -1.06 & $(-2.12)$ & $(-1.08)$ & -1.14 & $(-5.05)$ & -1.18 & $(-2.00)$ & $(-0.97)$ \\
\hline ABS & -0.0535 & $-0.2240^{* * *}$ & 0.0384 & $-0.1130^{*}$ & $-0.2200^{* * *}$ & -0.0535 & $-0.2240^{* * *}$ & 0.0366 & $-0.1160^{*}$ & $-0.2240^{* * *}$ \\
\hline $\mathrm{ACCR}$ & $(-1.62)$ & $(-6.20)$ & -1.11 & $(-1.88)$ & $(-3.18)$ & $(-1.62)$ & $(-6.21)$ & -1.06 & $(-1.94)$ & $(-3.23)$ \\
\hline \multirow{2}{*}{ CONS } & $-0.154^{* * *}$ & $0.546^{* * *}$ & $0.187^{* * *}$ & $0.770^{* * *}$ & $0.562^{* * *}$ & $-0.154^{* * *}$ & $0.544^{* * *}$ & $0.189^{* * *}$ & $0.771^{* * *}$ & $0.565^{* * *}$ \\
\hline & $(-4.64)$ & -15.09 & -5.34 & -12.68 & -7.99 & $(-4.62)$ & -15.04 & -5.39 & -12.71 & -8.03 \\
\hline$N$ & 33168 & 32580 & 31097 & 31097 & 31097 & 33168 & 32580 & 31097 & 31097 & 31097 \\
\hline $\operatorname{adj} . R^{2}$ & 0.515 & 0.166 & 0.11 & 0.062 & 0.204 & 0.515 & 0.166 & 0.11 & 0.062 & 0.204 \\
\hline
\end{tabular}

$t$ statistics in parentheses

${ }^{*} p<0.10,{ }^{* *} p<0.05,{ }^{* * *} p<0.01$ 


\section{ESSAY 3: REAL EARNINGS MANAGEMENT AND FUTURE PERFORMANCE}

\section{Motivation}

Emerging research on real earnings management [REM] has expressed the concern that firms deviating from normal business practices may endure a negative impact on future cash flows and performance. Not all studies have, however, found a negative impact of REM on future performance. As a consequence, a new stream of research is emerging that examines whether actions that would mechanically be identified as REM are truly earnings management, or are, simply efficient business activities. I further this stream of inquiry by identifying factors: restructurings; and expectations of future sales growth, that can be useful in making a distinction between earnings management and "just business."

The main objective of financial reporting is to provide information about a company's performance. The Financial Accounting Standard Board's [FASB] Statement of Financial Accounting Concept No. 1 defines earnings as an important component in assessing companies' performance. This is because earnings are used as a summary measure of firm performance (Dechow 1994) that incorporates the activities of a firm over specific periods of time.

The traditional view of accounting information is that it plays an informativeness role for external evaluators (Ronen 1979; Gjesdal 1989; Dye 1988). Consistent with this view, a number of studies show that accounting earnings are used by capital markets in

pricing debt and equity (Ball and Brown 1968; Bernard and Thomas 1990; Ou and Penman 1989). Because accounting numbers reflect performance, they also serve as a 
basis for the contractual arrangements of the firm, and because they are mutually observable, they play an important role in the contractual arrangements of executive compensation. This role, however, creates incentives for managers to manage earnings in order to increase their compensation (Watts and Zimmerman 1986).

According to Healy and Wahlen (1989) earnings management can be classified into two categories: accruals management and real earnings management. The former involves generally accepted accounting principles [GAAP], and occurs when managers manage reported earnings by using the discretion allowed under GAAP. The latter occurs when managers take actions that change the timing or structure of actual business activities.

The prevailing conjecture is that earnings management is costly to firms and shareholders, and several studies have focused on the economic consequences of accruals management. Xie (2001) for example, studies accruals management and long window equity returns. He finds that securities markets overprice earnings that are the result of manager's discretionary accruals. Consistent with this evidence, Sloan (1996) offers the conjecture that the lower persistence of earnings performance that results from the accrual component of earnings, may be due to the earnings management. Similarly Bartov, Givoly and Hayn (2002) show that the future performance of firms that manage accruals to meet analysts' earnings forecasts is inferior to that of firms that do not engage in accruals management.

Real earnings management has received considerable attention since Graham, Harvey and Rajgopal (2005) reported that $80 \%$ of U.S. executives surveyed were willing to reduce expenditures on $\mathrm{R} \& \mathrm{D}$, advertising, and maintenance in order to meet earnings 
benchmarks. Their finding is significant in that it suggests that managers in the U.S. may be willing to sacrifice the future performance of their companies in order to meet current period financial reporting targets.

After SOX, managers have reduced the use of accruals management and increased the use of REM (Cohen, Dey and Lys 2008). This trade off has also been attributed to the higher levels of auditor and regulator scrutiny (Zang 2012). Furthermore, this phenomenon has affected the auditor-client relationship. Kim and Park (2014) find, for example, that firms with high levels of REM are associated with a higher likelihood of auditor resignation.

Emerging research on real earnings management has also expressed the concern that firms manipulating their operations to manage earnings, and thus deviating from normal business practices, may endure a negative impact on future cash flows and performance. As a consequence real earnings management may be costly to shareholders since it may reduce firm value (Ewert and Wagenhofer 2005; Ronen and Yaari 2008; Badertscher 2011). Roychowdhury (2006) also suggests that real earnings management has negative consequences for future cash flows, and evidence indicates that markets see through cash flow manipulation and factor that into an increased cost of capital (Kim and Sohn 2013).

Long-term performance may, for example, be negatively impacted by: temporary price discounts or more lenient credit terms that lower margins on future sales; reductions in valuable investments in research and development and SG\&A activities; and/or by increasing investments in unneeded inventories via over-production. If this conjecture is 
correct, then these negative long-term prospects should be incorporated into investor expectations.

Not all studies have, however, found a negative impact of REM on future performance. Gunny (2010) for example, suggests that managers may engage in REM to convey information about future growth prospects. She finds increased ROA following REM activities that allowed firms to meet earnings targets. Therefore, it is possible that only managers who are confident about the prospects for improved future performance will engage in REM.

Similarly, various activities (e.g., reductions in discretionary expenses following a restructuring), an activity that would be identified as REM, could result in real improvements in firm performance. Cready, Lopez and Sisneros (2012) note: "Take, for example, the case of a firm that undertakes a restructuring of operations. If the restructuring includes a workforce reduction and plant closing, then the firm may realize future efficiency gains from reduced payroll expenses and operating expenses associated with running the plant" (page 1166). They go on to write that "operating cash flows are less susceptible to temporal manipulation," and their evidence suggests that the increases in earnings they document "are more likely to be the result of real improvements" (page 1194). Similarly, firms may overproduce not to manage earnings, but in expectation of future sales growth (Thomas and Zang 2002). In other words, what may mechanically appear to be REM, may in fact be just business.

As a consequence, a new stream of research is emerging that examines whether actions that would mechanically be identified as REM are truly earnings management, or are, simply efficient business activities. Vorst (2015), for example, identifies a 
circumstance - the reversal of abnormal reductions in discretionary expense - that facilitates financial statement users in distinguishing between REM and efficient managerial actions. I further this stream of inquiry by identifying additional factors that can be useful in making this distinction.

\section{Prior Literature}

\section{Consequences of REM}

A stream of research has focused on the economic consequences of REM. This research has examined the opportunism-based REM theory where managers engage in suboptimal levels of real activities in order to meet a performance target. A recent paper by Kothari, Mizik and Roychowdhury (2016), extends the study by Cohen and Zarowin (2010) by examining the opacity of earnings management. The study examines postseasoned equity offering [SEO] returns and the role of accruals versus real activities in inducing SEO overvaluation. The authors report a significantly negative future return when accruals management is used simultaneously with $R \& D$ or SG\&A reduction to generate high earnings during an SEO. This finding suggests that investors cannot detect earnings management when real activities are the basis of that management.

Kim and Sohn (2013), investigate the influence of REM on firms' cost of capital. Their study documents a positive association between the cost of equity and REM. Using the average of three implied costs of equity, Beta, Size (log of market capitalization) and the Book-to-Market ratio, they find that stock markets penalize firms that engage in REM activities by imposing a higher cost of capital. This link between REM and the cost of equity relies on the argument that when REM deteriorates reporting quality, it increases the noise in future cash flows, which in turn increases the expected cost of capital. 
An increase on the cost of equity is not the only economic consequence of REM. REM may also have an impact on firms' credit and bond ratings. Using the bond yield spread and the bond rating of firms that issued new bonds during 1993-2009, Ge and Kim (2014), examine the effect of REM on the bond market. Their results suggest that bondholders perceive REM as a credit risk, because bondholders tend to focus on firms' ability to generate future cash flows. The deviation from optimal operations thus negatively affects the quality of the accounting information and the bondholders' forecasts of future cash flows. This results in higher risk premiums.

The impact of REM on stock prices has also been studied. Francis, Hasan and Li (2014) find that the less transparent a firm is, the larger the amount of bad news information it can hide. When, however, the capital markets observe the hidden negative information the stock price experiences a crash. The authors find a strong positive association between REM and the likelihood of a stock price crash in the next period.

In analyzing firms that adopted a compensation clawback provision, Chan, Chen, Chen and $\mathrm{Yu}$ (2015) find that firms with increased REM exhibit a higher ROA in the year of the increased REM but subsequent years are characterized by declines in ROA. This is consistent with Gunny's (2010) finding that firms that just meet earnings benchmarks by engaging in REM have significantly higher subsequent industry-adjusted ROA than firms that do not. Based on this result, she suggests that REM may be a mechanism firms use to signal future performance to the capital markets. Chan et al. (2015) suggest, however, that the increased ROA may be short-lived. Zhao, Chen, Zhang and Davis (2012) find, for example, that when firms fail to meet benchmark targets, REM is negatively 
associated with future performance, while REM coincident with meeting benchmarks is positively associated with future performance.

\section{Restructuring Charges}

A corporate restructuring is defined as a change of the business strategy or structure to improve a firm's future operations. Traditionally restructuring charges include costs such as the cost of laying-off/terminating employees, the cost of eliminating product lines, the cost to consolidate or relocate operations, losses on disposal of assets and losses relating to impairment. According to Atiase, Platt and Tse (2004) an operational restructuring is a common corporate reaction to poor performance. Thus, they examine whether firm performance improves after a restructuring. Their results reveal a positive association between restructuring charges and changes in operating income. Their findings are, however, mixed regarding cash from operations. Cready et al. (2012) show, however, that corporate restructurings should result in improved firm performance and that this should be reflected in operating cash flows.

In 2002 the Financial Accounting Standard Board (FASB) issued changes to SFAS 146, which modified the way companies account for restructuring costs. Lee (2014) predicts that the new requirement (to recognize restructuring costs when incurred) will result in smaller and more frequent charges. These smaller charges will, therefore, have a smaller effect on future earnings. That research highlights the notion that normal charges are more likely to improve firm performance, because they result in fundamental improvements.

Based on the above, I hypothesize that REM is not always "earnings management" in a negative sense. What may be thought to be REM can be "just 
business." Thus, I predict that firms that are identified as engaging in REM subsequent to a restructuring will have better financial performance. My first hypothesis (in alternative form) is thus:

H1: Firms that engage in REM subsequent to a restructuring will exhibit improved operating performance while those that engage in REM absent a restructuring will not.

\section{Sales Growth}

Prior research documents that managers choose to overproduce in order to manipulate reported earnings. Firms could overproduce opportunistically to meet current period demand, and therefore allocate a portion of current period fixed costs from cost of goods sold to inventory. Roychowdhury (2006) finds that managers have incentives to over-produce in order to influence their earnings and avoid losses. Furthermore, inventory buildups convey a strong negative signal to investors, since they indicate the presence of slow-moving products that may have to be written off in the future (Lev and Thiagaranjan 1993). On the other hand, overproduction may indicate good news because managers expect sales to increase in the future. According to Jiambalvo, Noreen and Shevlin (1997), "managers may increase the percent of production added to inventory in anticipation of an increase in sales. Such behavior is clearly not opportunistic" (p 73). Overall, however, prior research does not clearly explain whether earnings management or general business management is the cause of changes in inventory.

Lev and Thiagaranjan (1993) in examining the role of fundamentals in security valuation, analyze 12 fundamentals that provide signals to investors about the quality of a firm's earnings. They find a negative association between stock returns and the inventory 
signal. That is, a disproportionate increase in inventory is a negative signal to the stock market because it suggests difficulties in generating sales.

The negative effect of overproduction on firm value has also been observed for U.S. auto manufacturers. Bruggen, Krishnan and Sedatole (2011) find that automotive firms that over-produce subsequently incur an increase in the cost of customer incentives and advertising expenditures. The results of their field interviews indicate that the inventory buildup deteriorates the brand image of the firm.

Similar to Roychowdhury (2006), Young, Peng, Chien and Tsai (2014) examined a sample of U.S manufacturing companies for the period 2003 to 2008, and find that after the adoption of SFAS No. 151 overproduction is exacerbated for firms that lack accrual management flexibility but have pressure to meet or beat earnings benchmarks. This study, furthermore, shows that overproduction is expensive because it diminishes economic income and firm value in the long-term.

Firms' fixed cost structures provide a more complete explanation on how overproduction results in higher accounting performance. Gupta, Pevzner and Seethamraju (2010), investigate the relation between fixed costs and performance. Their evidence reveals a significant association between overproduction and contemporaneous return on assets for firms with higher fixed costs and with incentives to overproduce. Their results indicate that the failure to adjust production after a decrease in demand (a delayed reaction) is not the reason for overproduction.

Alternatively Jiambalvo et al. (1997), in exploring the change in the percent of production added to the inventory, find that it may not be an indicator of managers 
behaving opportunistically. Instead, they find that it is an indicator that managers expect future growth in sales.

When managers face incentives to meet earnings threshold they are likely to reduce resources, in order to meet the earnings target. According to Kama and Weiss (2013) when sales drop, managers respond by cutting costs more aggressively when they face incentive targets. The authors investigate the effect of incentives to meet earnings targets on firm cost structure. Focusing on operating costs (i.e., the costs of providing goods/services and the cost of marketing and distribution), the authors find that without incentives to avoid losses the costs are sticky. When, however, managers have pressure to meet earning benchmarks the costs become less sticky.

The consequences of cutting resources may affect the future performance of the firm since firms may incur extra costs in the future in order to replace the resources that were cut before. For example, managers incur dismissal costs during the post-dismissal adjustment process and then later incur training costs when new employees are hired. Anderson, Banker and Janakiraman (2003) indicate that in addition to the training costs, firms face organizational costs such as loss of morale and erosion of human capital.

Similarly, firms may overproduce to shift fixed costs to inventory. They may also overproduce, however, because they anticipate future cost increases. According to Anderson, Banker, Huang and Janakiraman (2007) the SG\&A cost ratio is a signal of future earnings changes. An increase in this ratio may indicate that resources are being used less efficiently, while a decrease in the ratio may show that managers have better control over costs. Typically this signal applies during revenue-increasing periods, because an increase in business activities requires managers to add more resources to 
meet demand. The SG\&A ratio therefore may provide evidence of the managers' efficiency in controlling costs when the ratio declines. This traditional view is not true, however, in all circumstances. When revenue declines, a company's cost structure affects manager's decisions to maintain resources. An increase in the SG\&A cost ratio may thus be caused by managers' decisions to maintain slack resources without adjustment, and may reflect manager's expectations regarding future performance.

Based on the above, and the conjecture that REM may be "just business", I predict that firms that engage in REM and, in parallel, experience sales growth will have better financial performance. My second hypothesis (in alternative form) is thus:

H2: Firms that are identified as engaging in REM while experiencing growth in future sales will exhibit improved operating performance while those that engage in REM absent a growth in sales will not.

\section{Research Method}

To measure real earnings management, I rely on two of the proxies of Roychowdhury (2006): abnormal discretionary expenses; and abnormal production costs. In order to measure these variables, it is necessary to generate the normal levels of discretionary expenses [DX], and production costs [PC].

The residuals from the following models serve as the measures of REM: abnormal discretionary expenses [REMDISC]; and abnormal production costs [REMPROD]. To obtain the residuals, I run the following cross sectional regression for each real management activity. 
Discretionary expenses:

$\frac{\operatorname{DX}_{t}}{\operatorname{ASSETS}_{t-1}}=\alpha_{0} \frac{1}{\operatorname{ASSETS}_{t-1}}+\alpha_{1} \frac{\operatorname{SALES}_{t-1}}{\operatorname{ASSETS}_{t-1}}+\varepsilon_{t}$

Where DX is discretionary expense measured as the sum of advertising expense, R\&D, and selling, general, and administrative expenses, ASSETS is total assets, and SALES is net sales.

Production costs:

$$
\begin{aligned}
\frac{\mathrm{PC}_{t}}{\operatorname{ASSETS}_{t-1}}= & \alpha_{0} \frac{1}{\operatorname{ASSETS}_{t-1}}+\alpha_{1} \frac{\operatorname{SALES}_{t}}{\operatorname{ASSETS}_{t-1}}+\alpha_{2} \frac{\Delta \operatorname{SALES}_{t}}{\operatorname{ASSETS}_{t-1}}+\alpha_{3} \frac{\Delta \operatorname{SALES}_{t-1}}{\operatorname{ASSETS}_{t-1}} \\
& +\varepsilon_{t}
\end{aligned}
$$

Where PC is the sum of the COGS and change in inventory, $\triangle$ SALES is change in sales from time $\mathrm{t}-1$ to $\mathrm{t}$, and the other variables are as defined above.

The first question of interest is whether firms that are identified as engaging in REM coincident with a restructuring, have improved their operating practices while those that engage in REM absent a restructuring have not. This is because the restructuring may have a long-term positive impact on performance, as compared to REM driven by shortterm earnings objectives. Thus I examine whether REM has an effect on the future performance of firms, after controlling for restructurings.

I employ ROA, future stock returns and firm's industry-adjusted cash flows from operating activities as measures of future financial performance. The dependent variables are: one, two and three years ahead values. My test model is:

Future Performance $=\beta_{0}+\beta_{1}$ REMDISC $+\beta_{2}$ RESTRUC $+\beta_{3}$ REMDISC $x$ RESTRUC $+\beta_{4}$ REMDISC $x$ BENCHMARK $+\beta{ }_{5}$ REMDISC $x$ RESTRUC $x$ 
BENCHMARK $+\beta_{6}$ LGTA $+\beta_{7}$ MTB + Year $\&$ Industry Fixed Effects +

$\varepsilon$

where Future Performance is: 1) return on assets, and 2) annual stock returns; RESTRUC is an indicator variable equal to 1 if the firm had restructuring expense in the year. All indicator variables not equal to 1 are set equal to 0 . BENCHMARK is either MEET or MEETBEAT where MEET is an indicator variable equal to 1 if net income divided by beginning total assets is greater than or equal to zero but less than 0.01 and MEETBEAT is an indicator variable equal to 1 if net income is greater than zero and greater than the prior fiscal year's net income.

My second question of interest is whether overproduction is representative of REM, or whether it may represent 1) anticipated future sales growth, 2) anticipated future cost increases, or 3) both of these. For these tests, I employ future sales growth [FSGROW] and return on sales [ROS] as measures of future performance. My test model is:

Future Performance $=\beta_{0}+\beta_{1}$ REMROD $+\beta_{2}$ SGROW $+\beta_{3}$ REMPROD $\mathrm{x}$

$$
\begin{aligned}
& \text { SGROW }+\beta_{4} \text { BENCHMARK }+\beta_{5} \text { REMPROD x BENCHMARK }+ \\
& \beta_{6} \text { REMPROD x BENCHMARK x SGROW }+\beta_{7} \text { MTB }+\beta_{8} \text { LGTA }+ \\
& \beta_{9} \text { ITO }+\beta_{10} \text { ICOGS }+\beta_{11} \text { REMPROD x ICOGS }+\beta_{12} \text { INVTA }+ \\
& \text { Year } \& \text { Industry Fixed Effects }+\varepsilon
\end{aligned}
$$

Where FSGROW is the change in sales for the fiscal year at time $t+1$; SGROW is an indicator variable equal to 1 if current year sales growth is positive (year t-1 to t); ITO is inventory turnover; ICOGS is an indicator variable equal to 1 if the change in cost of 
goods sold as a percentage of revenues increases from time t- 1 to t; INVTA is total inventory as a percentage of average total assets; and all other variables are as defined above. All indicator variables not equal to 1 are set equal to 0 .

\section{Sample Selection}

Data were collected from Compustat for the 1988 through 2014 period. I chose 1988 as the beginning year because it was the first year for which statement of cash flows information was available. After deleting firms in the financial services industry, my sample is comprised of 11,895 unique firms that met my data requirements. Table 1 presents descriptive statistics for my sample. The mean (-.03) and interquartile range (.05 to 0.08 ) of ROA is stable across the $t+1$ through $t+3$ periods. RET is similarly stable (mean of 0.01 to 0.02 , and interquartile range of -0.39 to 0.08 ). FSGROW has a mean of 0.02 , a median value of 0.08 , and an interquartile range of -0.03 to 0.20 . ROS has a mean of -0.08 , a median of 0.03 and an interquartile range of -0.06 to 0.08 . The mean REMDISC is 0.08 with an interquartile range of -0.10 to 0.14 . Similarly, the mean of REMPROD is 0 with an interquartile range of -0.10 to 0.12 .

There are 4,063 firm years where sample firms had small positive earnings [MEET] but when I expand the criteria to include all those whose earnings exceeded those of the prior year [MEETBEAT] I get 27,690 firm years. There are 11,073 instances of restructuring charges and 71,276 where the rate of increase in sales is positive from t-1 to t. In 52,731 instances the cost of goods sold as a percentage of revenues increased from time $\mathrm{t}-1$ to $\mathrm{t}$. 


\section{Results}

\section{Return on Assets}

The results for my return on assets models are presented in Table $2 .^{1}$ The tests where MEET represents my suspect firms are presented in Panel A. The coefficients on REMDISC in this model are negative ( $p$-values $\leq 0.01)$. This is true for all three of the future periods. Similarly, the coefficients on RESTRUC are negative ( $p$-values $\leq 0.01$ ). The coefficients on the interaction of REMDISC and RESTRUC are, however, positive for periods $t+1$ and $t+2$. Taken together, these results support the general conjecture, that current period reductions in discretionary expense and restructurings are associated with poor future performance, but when a restructuring is coupled with cuts in discretionary expenses the impact on future performance is positive. I also find that while MEET is negatively associated with one-year ahead ROA, the interaction of MEET and REMDISC has a positive, but declining, association with future ROA.

The results for my tests when I expand the suspect firms to include all those without losses who beat prior year's earnings, MEETBEAT, are presented in Panel B. The results for these models are qualitatively identical to those reported in Panel A, with the notable exception of the significance of the coefficients on MEETBEAT. Where the coefficients on MEET were significant only in time $t+1$, the coefficients on MEETBEAT are positive (significant at the $p$-values $\leq 0.01$ level) in all three future periods. It is worth noting that low book-to-market ratios suggest that market participants have higher expectations of future growth.

\footnotetext{
${ }^{1}$ Fixed effects are not presented in the tables.
} 
Consistent with Francis, Hanna, and Vincent (1996) these results show that restructuring charges convey information about the future performance. Table 2 Panel A and Panel B, provide evidence of the effect of special items and REM on future performance. The coefficients on the interaction of REMDISC and RESTRUC suggest that restructuring charges in conjunction of real activity actions tend to be followed by an increase in Return on Assets. This phenomena, is described by Atiase et al. (2004) as indicative of an increase in operating efficiency leading to higher profits. Furthermore, the results also indicate that REM in conjunction with beating benchmarks provides a signal of expected improvements in future performance (Gunny 2010).

To some extent, these results clarify the idea that the reporting of restructuring charges in conjunction with managers' decisions to cut discretionary expenses, is not necessary opportunistic behavior even though it does represent a departure from normal operations. Rather than misleading investors (earnings management) it is signal of management taking action to change and improve the firm's situation.

\section{Stock Returns}

The results for my stock returns models are presented in Table 3. Panel A presents the results where MEET represents my suspect firms and Panel B presents the results where suspect firms are indicated by MEETBEAT. In both models, the coefficient on REMDISC is negative ( $p$-values $\leq 0.01$ ). In Panel A, restructuring is shown to be weakly, negatively associated with stock returns in year $\mathrm{t}+1$ and the interaction of REMDISC and RESTRUC is positively associated with stock returns in years $\mathrm{t}+1, \mathrm{t}+2$ and $\mathrm{t}+3$ ( $p$-values $\leq 0.05,0.01$ and 0.10 respectively). The coefficient on the interaction of REMDISC and MEET is significantly positive in year $t+1(p$-values $\leq 0.05)$ while the coefficients on the 
three-way interaction of REMDISC, RESTRUC and MEET are not significantly different from zero. Again, these results indicate that the reductions in discretionary expense that are associated with restructurings have a positive influence on future performance - in this case on future stock returns.

The results when MEETBEAT represents my suspect firms are consistent with those discussed above for MEET. Of importance, however, is that the coefficients on MEETBEAT are significantly positive in all periods ( $p$-values $\leq 0.01,0.05$, and 0.01 for years $t+1$ through $t+3$ respectively). The coefficient on the interaction of REMDISC and MEETBEAT is positive $(p$-values $\leq 0.05)$ at time $\mathrm{t}+1$. The coefficients on the three-way interactions are not significantly different from zero.

The results of these tests show that firms that reported restructuring charges (an example of special items) and engaged in discretionary expense reductions, reduced current period income but increased future income. This finding is consistent with what Burgstahler, Jiambalvo and Shevlin (2002) describe. Therefore, what prior research on real earnings management has indentified as improvements in reported performance driven by managers opportunistic behavior, may instead, be a response to serious financial issues in an attempt to help the company recover.

\section{Future Sales Growth}

The results for my future sales growth (and future return-on-sales) models are presented in Table 4. The coefficients on REMPROD are negative and significant in both the MEET (Panel A) and MEETBEAT (Panel B) models ( $p$-values $\leq 0.05$ and 0.01 respectively). This suggests that overproduction may be the result of errors in predicting demand, or that it may be indicative of REM. The coefficients on SGROW are positive 
( $p$-values $\leq 0.01)$. This indicates that current year sales growth is highly, positively associated with future period's sales growth. Contrary to the results for REMPROD by itself, however, the coefficients on the interaction of REMPROD with SGROW are significantly positive ( $p$-values $\leq 0.01)$. Thus when current period sales are increasing, over production is associated with sales increases in future periods. This suggests that when sales are increasing, overproduction is not REM, but instead is done in anticipation of increased future sales. The coefficients on MEET and MEETBEAT are both positive (MEET marginally so at $p$-values $\leq 0.10$ ). This result is consistent with the notion that growth in sales will lead to growth in income. The coefficients on the interaction of MEET or MEETBEAT, with REMPROD are negative. This suggests that overproduction to meet earnings benchmarks is indicative of declines in future sales. The coefficients on the three-way interaction are not statistically different from zero.

These results suggest that SGROWTH in conjunction with PROD provides positive information about future earnings during periods in which managers overproduce. This is a signal of operating efficiency. Therefore, an increase in sales coupled with an increase in production, are informative about managers expectations of future firm performance.

\section{Future Cost of Goods Sold}

With respect to my measures for cost-of-goods sold (ITO and ICOGS), the coefficients are significantly negative ( $p$-values $\leq 0.01)$. The coefficients on the interaction of ICOGS and REMPROD are, however, positive ( $p$-values $\leq 0.01$ ). I interpret this as indicating that overproduction when the cost of production is increasing, may be a cost minimization strategy in that over-production in the current period delays 
the impact of anticipated future cost increases. This strategy is, therefore, indicative of managers using internal information about the administration of the firm's costs to maximize future performance. I conclude from these tests that over-production is not indicative of REM solely when it is coupled with earnings that meet or beat benchmarks. Rather it is indicative of REM when over-production and meet or beat, are coupled with declining sales growth.

\section{Return on Sales}

The coefficients on REMPROD when ROS is the dependent variable are, as I would expect, significantly positive ( $p$-values $\leq 0.01$ ), as are the coefficients on SGROW, MEET and MEETBEAT. As is the case for the FSGROW models, the coefficients on the interaction of MEET and MEETBEAT with REMPROD are significantly negative ( $p$ values $\leq 0.01)$. The coefficients on the three-way interaction of REMPROD, SGROW and MEET (MEETBEAT) are, however, significantly positive ( $p$-values $\leq 0.05$ and 0.10 respectively). This indicates that when sales are growing, the incidence of overproduction and meeting earnings benchmarks may be indicative of improved future performance rather than REM. The coefficient on the interaction of REMPROD with ICOGS is significant at the $p \leq 0.05$ level in the MEETBEAT model, but is not significantly different from zero in the MEET model.

\section{Summary}

In light of Vorst's (2015) findings that particular incentives, and other factors such as reputation, violation of debt covenants and compensation contracts have long term consequences, this paper contributes by adding restructuring charges and sales growth as operating environment factors that capture distinctions between real earnings 
management and decisions that are "just business." The evidence suggests that restructuring charges accompanied by REM, are indicative of managerial efforts to improve the long-term profitability. Furthermore, I find that future sales growth is associated with changes in sales and overproduction, and that a departure from the normal levels of production coupled with positive growth in sales is evidence of mangers using resources more efficiently, not a signal of earnings management. In contrast, I find that overproduction coupled with a decrease in sales is indicative of earnings management.

In summary, I test whether business activites that are indicative of REM, may instead be indicative of improved operating performance. I find that when I control for restructurings, reductions in discretionary expenses that would ordinarly be indicative of REM are instead associated with improved future ROA and secutity returns. I further find that when I control for future sales growth, overproduction is also associated with improved ROS as it is with future increases in cost of goods sold. Together, these results may explain the contradictory results presented in prior research with respect to the imapct of REM on future performance - that is, some of what has been identified as REM in prior studies may, in fact, be "just business."

\section{List of References}

Anderson, M., R. Banker, and S. Janakiraman. 2003. Are selling general, and administrative cost sticky?. Journal of Accounting Research 41 (1): 47-63.

. R. Banker, R. Huang, and S. Janakiraman. 2007. Cost behavior and fundamental analysis of SG\&A costs. Journal of Accounting, Auditing \& Finance 22 (1): 1-28.

Atiase R., D. Platt, and S. Tse. 2004. Operational Restructuring Charges and PostRestructuring Performance. Contemporary Accounting Research 21(3): 493-522. 
Badertscher, B. 2011. Overvaluation and the choice of alternative earnings management mechanism. The Accounting Review 86 (5): 1491-1518.

Ball, R., and P. Brown. 1968. An empirical evaluation of accounting income numbers. Journal of Accounting Research 6 (2): 159-178.

Bartov, E., D. Givoly, and C. Hayn. 2002. The rewards to meeting or beating earnings expectations. Journal of Accounting and Economics 33: 173-2004.

Bernard, V., and J. Thomas. 1990. Evidence that stock prices do not fully reflect the implications of current earnings for future earnings. Journal of Accounting and Economics 13: 305-340.

Bruggen, A., R. Krishnan, and K. Sedatole. 2011. Drivers and consequences of shortterm production decisions: evidence from the auto industry. Contemporary Accounting Research 28 (1): 83-123.

Burgstahler, D, J. Jiambalvo, and T. Shevlin. 2002. Do stock prices fully reflect the implications of special item for future earnings? Journal of Accounting Research 40 (3): 586-612.

Chan, L., K. Chen, T. Chen, and Y. Yu. 2015. Substitution between real and accrualsbased earnings management after voluntary adoption of compensation clawback provisions. The Accounting Review 90 (1) :147-174.

Cohen, D., A. Dey, and T. Lys. 2008. Real and accrual-based earnings management in the pre- and post-Sarbanes-Oxley periods. The Accounting Review 83 (3): 757787.

.2010. Accrual based and real earnings management activities around seasoned equity offerings. Journal of Accounting and Economics 50: 2-19.

Cready, W., T. Lopez, and C. Sisneros. 2012. Negative Special Items and Future Earnings: Expense Transfer or Real Improvements? The Accounting Review 87 (4): 1165-95.

Dechow, P. 1994. Accounting earnings and cash flows as measures of firm performance. The role of accounting accruals. Journal of Accounting and Economics 18: 3-42.

Dye, R. 1988. Earnings management in an overlapping generations model. Journal of Accounting Research 26 (2): 195-235.

Ewert, R., and A. Wagenhofer. 2005. Economic effect of tightening accounting standards to restrict earnings management. The Accounting Review 80 (4): 1101-1124. 
Francis, B., I. Hasan, and L. Li. 2014. Abnormal real operations, real earnings management, and subsequent crashes in stock prices. Review of Quantitative Finance and Accounting 46 (2): 217-260.

Francis, J., J. Hanna, and L. Vincent. 1996. Causes and effects of discretionary asset write-offs. Journal of Accounting Research 34 (Supplement):117-34

Ge, W., and J. Kim. 2014. Real earnings management and the cost of new corporate bonds. Journal of Business Research 67: 641-647.

Gjesdal, F. 1989. Piecewise linear incentive schemes. En S. Honkapohja, Information and Incentives in Organizations (Ch. 2). Blackwell, UK.

Graham, J., C. Harvey, and S. Rajgopal. 2005. The economic implications of corporate financial reporting. Journal of Accounting and Economics 40: 3-73.

Gunny, K. 2010. The relation between earnings management using real activities manipulation and future performance: evidence from meeting earnings benchmark. Contemporary Accounting Research 27 (1): 855-888.

Gupta, M., M. Pevzner, and C. Seethamraju. 2010. The implications of absorption cost accounting and production decisions for future firm performance and valuation. Contemporary Accounting Research 27 (3): 889-922.

Healey, P., and J. Wahlen. 1999. A review of the earnings mamangement literature and its implication for standar setting. Accounting Horizons 13 (4): 365-383.

Jiambalvo, J., E. Noreen, and T. Shevlin. 1997. Incremental information content of the change in the percent of production added to inventory. Contemporary Accounting Research 14 (1): 69-97.

Kama, I., and D. Weiss. 2013. Do earnings targets and managerial incentives affect sticky costs? Journal of Accounting Research 51 (1): 201-224.

Kim, J. and M. Park. 2014. Real activities manipulation and auditors client retention decisions. The Accounting Review 89 (1): 367-401.

. and B. Sohn. 2013. Real earnings management and cost of capital. Journal of Accounting Public Policy 32 (2): 518-543.

Kothari, S., N. Mizik, and S. Roychowdhury. 2016. Managing for the moment: the role of earnings management via real activities versus accruals in SEO valuation. The Accounting Review 91 (2): 559-586.

Lee, Y. 2014. An examination of restructuring charges surrounding the implementation of SFAS 146. Review of Accounting Studies 19 (2): 539-572. 
Lev, B., and R. Thiagaranjan. 1993. Fundamental Information Analysis. Journal of Accounting Research 31 (2): 190-215.

Ou, J., and S. Penman. 1989. Financial statement analysis and the prediction of stock return. Journal of Accounting and Economics, 11 (November): 295-330.

Ronen, J. 1979. The dual role of accounting: A financial economic perspective. En J. L. Bicksler, Handbook of Financial Economics (pages. 415-454). North-Holland, Amsterdam.

Ronen, J., and V. Yaari. 2008. Earnings management: Emerging insights in theory, practice and research. New York: Springer Science.

Roychowdhury, S. 2006. Earnings management through real activities manipulation. Journal of Accounting and Economics 42: 335-370.

Sloan, R. 1996. Do stock prices fully reflect information in accruals and cash flows about future earnings? The Accounting Review 71:(3) 289-315.

Thomas, J., and H. Zhang. 2002. Inventory changes and future returns. Review of Accounting Studies 7: 163-187.

Vorst, P. 2015. Real earnings management and long-term operating performance: the role of reversals in discretionary investments cuts. The Accounting Review, in-press http://dx.doi.org/10.2308/accr-51281.

Watts, R., and J. Zimmerman. 1986. Positive accounting theory, Prentice Hall, Englewood Cliffs, NJ.

Xie, H. 2001. The mispricing of abnormal accruals. The Accounting Review 76 (3): $357-$ 373.

Young, C-S., C-W. Peng, C-C. Chien and L-C. Tsai. 2014. Does SFAS No. 151 trigger more overproduction? Journal of Management Accounting Research 26 (1): 121143.

Zang, A. 2012. Evidence on the Trade-Off between Real Activities Manipulation and accrual-Based Earnings Management. The Accounting Review 87 (2): 675-703.

Zhao, Y., K. Chen, Y. Zhang, and M. Davis. 2012. Takeover protection and managerial myopia: Evidence from real earnings management. Journal Accounting Public Policy 31: 109-135. 


\section{Table 1 Descriptive Statistics}

\begin{tabular}{|c|c|c|c|c|c|}
\hline Variable & Mean & S.D. & $\underline{0.25}$ & Median & $\underline{0.75}$ \\
\hline $\mathrm{ROA} \mathrm{t}+1$ & -0.03 & 0.30 & -0.05 & 0.03 & 0.08 \\
\hline $\mathrm{ROA} \mathrm{t}+2$ & -0.03 & 0.28 & -0.05 & 0.03 & 0.08 \\
\hline ROA t+3 & -0.03 & 0.28 & -0.05 & 0.03 & 0.08 \\
\hline RET t to $\mathrm{t}+1$ & 0.01 & 0.15 & -0.39 & 0.00 & 0.08 \\
\hline RET $\mathrm{t}+1$ to $\mathrm{t}+2$ & 0.01 & 0.15 & -0.38 & 0.01 & 0.08 \\
\hline $\operatorname{RET} \mathrm{t}+2$ to $\mathrm{t}+3$ & 0.02 & 0.15 & -0.37 & 0.01 & 0.08 \\
\hline FSGROW & 0.02 & 0.52 & -0.03 & 0.08 & 0.20 \\
\hline ROS t+1 & -0.08 & 0.31 & -0.06 & 0.03 & 0.08 \\
\hline REMDISC & 0.08 & 0.41 & -0.10 & 0.00 & 0.14 \\
\hline RESTRUC & 0.11 & 0.31 & 0.00 & 0.00 & 0.00 \\
\hline SIZE & 5.08 & 2.22 & 3.48 & 4.93 & 6.57 \\
\hline $\mathrm{BM}$ & 0.65 & 0.75 & 0.27 & 0.50 & 0.84 \\
\hline REMPROD & 0.00 & 0.27 & -0.1 & 0.00 & 0.12 \\
\hline MB & 2.96 & 4.78 & 1.11 & 1.90 & 3.40 \\
\hline INVTA & 0.04 & 0.14 & 0.00 & 0.01 & 0.03 \\
\hline \multirow[t]{2}{*}{ ITO } & 16.29 & 39.27 & 3.00 & 5.01 & 10.31 \\
\hline & $\underline{\mathrm{n}}$ & & & & \\
\hline MEET & 4063 & & & & \\
\hline MEETBEAT & 27690 & & & & \\
\hline RESTRUC & 11073 & & & & \\
\hline SGROW & 71276 & & & & \\
\hline ICOGS & 52731 & & & & \\
\hline
\end{tabular}


Table 2 Regressions of Abnormal Discretionary Expense on Return on Assets Panel A - MEET earnings benchmark

\begin{tabular}{|c|c|c|c|}
\hline & $\mathrm{ROA} \mathrm{t+1}$ & $\mathrm{ROA} \mathrm{t}+2$ & $\mathrm{ROA} \mathrm{t}+3$ \\
\hline \multirow[t]{2}{*}{ REMDISC } & $-0.143^{* * *}$ & $-0.115^{* * *}$ & $-0.0932^{* * *}$ \\
\hline & $(-59.19)$ & $(-46.74)$ & $(-35.25)$ \\
\hline \multirow[t]{2}{*}{ RESTRUC } & $-0.0372^{* * *}$ & $-0.0284^{* * *}$ & $-0.0241^{* * *}$ \\
\hline & $(-11.62)$ & $(-8.66)$ & $(-6.74)$ \\
\hline \multirow[t]{2}{*}{ REMDISC * RESTRUC } & $0.0394^{* * *}$ & $0.0412^{* * *}$ & 0.0187 \\
\hline & (3.39) & $(3.41)$ & $(1.37)$ \\
\hline \multirow[t]{2}{*}{ MEET } & $-0.0116^{* *}$ & -0.00540 & -0.00439 \\
\hline & $(-2.56)$ & $(-1.19)$ & $(-0.91)$ \\
\hline \multirow[t]{2}{*}{ REMDISC * MEET } & $0.183^{* * *}$ & $0.157^{* * *}$ & $0.136^{* * *}$ \\
\hline & $(24.17)$ & $(20.78)$ & $(16.99)$ \\
\hline \multirow[t]{2}{*}{ REMDISC * RESTRUC * MEET } & 0.0125 & -0.00165 & 0.0100 \\
\hline & $(0.50)$ & $(-0.07)$ & $(0.37)$ \\
\hline \multirow[t]{2}{*}{ SIZE } & $0.0350^{* * *}$ & $0.0347^{* * *}$ & $0.0342^{* * *}$ \\
\hline & $(75.40)$ & $(75.37)$ & $(70.36)$ \\
\hline \multirow[t]{2}{*}{$\mathrm{BM}$} & -0.00113 & 0.00121 & $0.00296^{* *}$ \\
\hline & $(-0.90)$ & $(0.94)$ & $(2.14)$ \\
\hline \multirow[t]{2}{*}{ _cons } & $-0.298^{* * *}$ & $-0.232^{* * *}$ & $-0.229^{* * *}$ \\
\hline & $(-24.44)$ & $(-12.95)$ & $(-12.18)$ \\
\hline$N$ & 95552 & 86180 & 77508 \\
\hline $\operatorname{adj} . R^{2}$ & 0.139 & 0.132 & 0.117 \\
\hline
\end{tabular}

$t$ statistics in parentheses

${ }^{*} p<0.10,{ }^{* *} p<0.05,{ }^{* * *} p<0.01$ 
Table 2 Continued

Panel B - MEETBEAT earnings benchmark

\begin{tabular}{|c|c|c|c|}
\hline & ROA t+1 & $\mathrm{ROA} \mathrm{t}+2$ & $\mathrm{ROA} \mathrm{t}+3$ \\
\hline \multirow[t]{2}{*}{ REMDISC } & $-0.140^{* * *}$ & $-0.111^{* * *}$ & $-0.0899^{* * *}$ \\
\hline & $(-57.79)$ & $(-45.44)$ & $(-34.05)$ \\
\hline \multirow[t]{2}{*}{ RESTRUC } & $-0.0342^{* * *}$ & $-0.0254^{* * *}$ & $-0.0211^{* * *}$ \\
\hline & $(-10.70)$ & $(-7.76)$ & $(-5.93)$ \\
\hline \multirow[t]{2}{*}{ REMDISC * RESTRUC } & $0.0385^{* * *}$ & $0.0396^{* * *}$ & 0.0162 \\
\hline & $(3.32)$ & $(3.29)$ & $(1.19)$ \\
\hline \multirow[t]{2}{*}{ MEETBEAT } & $0.0511^{* * *}$ & $0.0476^{* * *}$ & $0.0454^{* * *}$ \\
\hline & $(24.90)$ & $(23.27)$ & $(21.00)$ \\
\hline \multirow[t]{2}{*}{ REMDISC $*$ MEETBEAT } & $0.180^{* * *}$ & $0.154^{* * *}$ & $0.134^{* * *}$ \\
\hline & $(23.81)$ & $(20.47)$ & $(16.79)$ \\
\hline \multirow[t]{2}{*}{ REMDISC * RESTRUC * MEETBEAT } & 0.0221 & 0.00814 & 0.0191 \\
\hline & $(0.89)$ & $(0.33)$ & $(0.71)$ \\
\hline \multirow[t]{2}{*}{ SIZE } & $0.0326^{* * *}$ & $0.0326^{* * *}$ & $0.0321^{* * *}$ \\
\hline & $(69.10)$ & $(69.53)$ & $(65.04)$ \\
\hline \multirow[t]{2}{*}{$\mathrm{BM}$} & $-0.00240^{*}$ & 0.0000572 & 0.00180 \\
\hline & $(-1.92)$ & $(0.04)$ & $(1.31)$ \\
\hline \multirow[t]{2}{*}{ Cons } & $-0.300^{* * *}$ & $-0.237^{* * *}$ & $-0.231^{* * *}$ \\
\hline & $(-24.74)$ & $(-13.26)$ & $(-12.32)$ \\
\hline$N$ & 95552 & 86180 & 77508 \\
\hline $\operatorname{adj} . R^{2}$ & 0.145 & 0.137 & 0.122 \\
\hline
\end{tabular}

$t$ statistics in parentheses

${ }^{*} p<0.10,{ }^{* *} p<0.05,{ }^{* * *} p<0.01$ 
Table 3 Regressions of Abnormal Discretionary Expense on Annual Stock Returns Panel A - MEET earnings benchmark

\begin{tabular}{|c|c|c|c|}
\hline & RET $\mathrm{t}$ to $\mathrm{t}+1$ & RET $\mathrm{t}+1$ to $\mathrm{t}+2$ & RET $\mathrm{t}+2$ to $\mathrm{t}+3$ \\
\hline \multirow[t]{2}{*}{ REMDISC } & $-0.0077^{* * *}$ & $-0.0079^{* * *}$ & $0.0062^{* * *}$ \\
\hline & $(-6.59)$ & $(-6.28)$ & $(-4.64)$ \\
\hline \multirow[t]{2}{*}{ RESTRUC } & $-0.0030 *$ & -0.0010 & 0.0018 \\
\hline & $(-1.95)$ & $(-0.60)$ & $(1.06)$ \\
\hline \multirow[t]{2}{*}{ REMDISC * RESTRUC } & $0.0143^{* *}$ & $0.0189^{* * *}$ & $0.0125^{*}$ \\
\hline & $(2.53)$ & $(3.00)$ & $(1.79)$ \\
\hline \multirow[t]{2}{*}{ MEET } & 0.0011 & -0.0029 & 0.0025 \\
\hline & $(0.52)$ & $(-1.32)$ & $(1.10)$ \\
\hline \multirow[t]{2}{*}{ REMDISC * MEET } & $0.0077^{* *}$ & 0.0037 & 0.0005 \\
\hline & $(2.18)$ & $(1.00)$ & $(0.14)$ \\
\hline \multirow[t]{2}{*}{ REMDISC * RESTRUC * MEET } & -0.0125 & 0.0066 & 0.0081 \\
\hline & $(-1.08)$ & $(0.54)$ & $(0.64)$ \\
\hline \multirow[t]{2}{*}{ SIZE } & $0.0059^{* * *}$ & $0.0059^{* * *}$ & $0.0055^{* * *}$ \\
\hline & $(27.03)$ & $(25.87)$ & $(23.55)$ \\
\hline \multirow[t]{2}{*}{$\mathrm{BM}$} & $-0.0046^{* * *}$ & $0.0017^{* *}$ & $0.0015^{* *}$ \\
\hline & $(-7.41)$ & $(2.49)$ & $(2.11)$ \\
\hline \multirow[t]{2}{*}{ Cons } & -0.0065 & $-0.0170^{*}$ & $-0.0264^{* * *}$ \\
\hline & $(-0.78)$ & $(-1.71)$ & $(-4.34)$ \\
\hline$N$ & 86557 & 76126 & 67156 \\
\hline $\operatorname{adj} . R^{2}$ & 0.044 & 0.047 & 0.046 \\
\hline
\end{tabular}

$t$ statistics in parentheses

${ }^{*} p<0.10,{ }^{* *} p<0.05,{ }^{* * *} p<0.01$ 
Table 3 Continued

Panel B - MEETBEAT earnings benchmark

\begin{tabular}{|c|c|c|c|}
\hline & RET $t$ to $\mathrm{t}+1$ & RET $t+1$ to $t+2$ & RET $t+2$ to $t+3$ \\
\hline \multirow[t]{2}{*}{ REMDISC } & $-0.0074^{* * *}$ & $-0.0077^{* * *}$ & $-0.0059^{* * *}$ \\
\hline & $(-6.29)$ & $(-6.09)$ & $(-4.47)$ \\
\hline \multirow[t]{2}{*}{ RESTRUC } & $-0.0028^{*}$ & -0.0009 & 0.0020 \\
\hline & $(-1.81)$ & $(-0.53)$ & $(1.15)$ \\
\hline \multirow[t]{2}{*}{ REMDISC * RESTRUC } & $0.0141^{* *}$ & $0.0187^{* * *}$ & $0.0123^{*}$ \\
\hline & $(2.49)$ & $(2.98)$ & $(1.76)$ \\
\hline \multirow[t]{2}{*}{ MEETBEAT } & $0.0041^{* * *}$ & $0.0024^{* *}$ & $0.0029^{* * *}$ \\
\hline & $(4.30)$ & $(2.37)$ & $(2.84)$ \\
\hline \multirow[t]{2}{*}{ DISEXP $*$ MEETBEAT } & $0.0076^{* *}$ & 0.0037 & 0.0005 \\
\hline & $(2.15)$ & $(1.02)$ & $(0.13)$ \\
\hline \multirow[t]{2}{*}{ REMDISC * RESTRUC * MEETBEAT } & -0.0117 & 0.0072 & 0.0086 \\
\hline & $(-1.01)$ & $(0.59)$ & $(0.68)$ \\
\hline \multirow[t]{2}{*}{ SIZE } & $0.0057^{* * *}$ & $0.0058^{* * *}$ & $0.0054^{* * *}$ \\
\hline & $(25.79)$ & $(24.97)$ & $(22.71)$ \\
\hline \multirow[t]{2}{*}{$\mathrm{BM}$} & $-0.0047^{* * *}$ & $0.0015^{* *}$ & $0.0015^{* *}$ \\
\hline & $(-7.55)$ & $(2.25)$ & $(2.14)$ \\
\hline \multirow[t]{2}{*}{ Cons } & -0.0070 & $-0.0175^{*}$ & $-0.0268^{* * *}$ \\
\hline & $(-0.85)$ & $(-1.76)$ & $(-4.40)$ \\
\hline$N$ & 86557 & 76126 & 67156 \\
\hline $\operatorname{adj} . R^{2}$ & 0.045 & 0.047 & 0.046 \\
\hline
\end{tabular}

$t$ statistics in parentheses

${ }^{*} p<0.10,{ }^{* *} p<0.05,{ }^{* * *} p<0.01$ 
Table 4 Regression of Over-Production on Year-Ahead Sales Growth and Return on Sales

\begin{tabular}{|c|c|c|c|c|}
\hline \multirow{3}{*}{ REMPROD } & FSGROW & FSGROW & $\operatorname{ROS~t+1}$ & $\operatorname{ROS} \mathrm{t}+1$ \\
\hline & $-0.0404^{* *}$ & $-0.0532^{* * *}$ & $0.369^{* * *}$ & $0.3904^{* * *}$ \\
\hline & $(-2.56)$ & $(-3.19)$ & $(26.28)$ & $(25.48)$ \\
\hline \multirow[t]{2}{*}{ SGROW } & $0.129^{* * *}$ & $0.129^{* * *}$ & $0.0950^{* * *}$ & $0.0935^{* * *}$ \\
\hline & $(32.36)$ & $(32.31)$ & $(30.71)$ & $(30.51)$ \\
\hline \multirow{2}{*}{$\begin{array}{l}\text { REMPROD } * \\
\text { SGROW }\end{array}$} & $0.0637^{* * *}$ & $0.0790^{* * *}$ & $-0.107^{* * *}$ & $-0.1018^{* * *}$ \\
\hline & $(4.10)$ & $(4.73)$ & $(-7.74)$ & $(-6.63)$ \\
\hline \multirow[t]{2}{*}{ MEET } & 0.0125 & & $0.0314^{* * *}$ & \\
\hline & $(1.38)$ & & $(4.63)$ & \\
\hline \multirow{4}{*}{$\begin{array}{l}\text { REMPROD } \\
\text { MEET } \\
\text { REMPROD * } \\
\text { SGROW * } \\
\text { MEET }\end{array}$} & $-0.151^{* *}$ & & $-0.400^{* * *}$ & \\
\hline & $(-2.08)$ & & $(-6.84)$ & \\
\hline & 0.0576 & & $0.147^{* *}$ & \\
\hline & $(0.66)$ & & $(2.11)$ & \\
\hline \multirow[t]{2}{*}{$\mathrm{MB}$} & $0.0042^{* * *}$ & $0.0044^{* * *}$ & $-0.0085^{* * *}$ & $-0.0078^{* * *}$ \\
\hline & $(11.86)$ & $(12.24)$ & $(-27.43)$ & $(-25.47)$ \\
\hline \multirow[t]{2}{*}{ SIZE } & $0.0171^{* * *}$ & $0.0154^{* * *}$ & $0.0448^{* * *}$ & $0.0401^{* * *}$ \\
\hline & $(21.90)$ & $(19.15)$ & $(59.57)$ & $(52.94)$ \\
\hline \multirow[t]{2}{*}{ ITO } & $-0.0002^{* * *}$ & $-0.0002^{* * *}$ & $-0.0003^{* * *}$ & $-0.0003^{* * *}$ \\
\hline & $(-4.22)$ & $(-4.12)$ & $(-9.68)$ & $(-9.09)$ \\
\hline \multirow[t]{2}{*}{ ICOGS } & $-0.0134^{* * *}$ & $-0.0182^{* * *}$ & $-0.0150^{* * *}$ & $-0.0283^{* * *}$ \\
\hline & $(-3.70)$ & $(-4.98)$ & $(-5.46)$ & $(-10.03)$ \\
\hline \multirow{2}{*}{$\begin{array}{l}\text { REMPROD * } \\
\text { ICOGS }\end{array}$} & $0.0383^{* * *}$ & $0.0420^{* * *}$ & 0.00268 & $0.0228^{* *}$ \\
\hline & $(2.93)$ & $(3.19)$ & $(0.25)$ & $(2.10)$ \\
\hline \multirow[t]{2}{*}{ MEETBEAT } & & $0.0397^{* * *}$ & & $0.1055^{* * *}$ \\
\hline & & $(9.49)$ & & $(34.22)$ \\
\hline \multirow{2}{*}{$\begin{array}{l}\text { REMPROD } * \\
\text { MEETBEAT }\end{array}$} & & 0.0033 & & $-0.2832^{* * *}$ \\
\hline & & $(0.10)$ & & $(-10.24)$ \\
\hline \multirow{2}{*}{$\begin{array}{l}\text { REMPROD * } \\
\text { SGROW * } \\
\text { MEETBEAT }\end{array}$} & & -0.0397 & & $0.0613^{*}$ \\
\hline & & $(-1.11)$ & & $(1.95)$ \\
\hline \multirow[t]{2}{*}{ INVTA } & & & $-0.3960^{* * *}$ & $-0.3868^{* * *}$ \\
\hline & & & $(-22.63)$ & $(-22.28)$ \\
\hline \multirow[t]{2}{*}{ cons } & $-0.105^{* * *}$ & $-0.107^{* * *}$ & $-0.373^{* * *}$ & $-0.377^{* * *}$ \\
\hline & $(-3.38)$ & $(-3.46)$ & $(-13.47)$ & $(-13.77)$ \\
\hline$N$ & 91222 & 91222 & 91222 & 91222 \\
\hline adj. $R^{2}$ & 0.039 & 0.040 & 0.169 & 0.184 \\
\hline
\end{tabular}

$t$ statistics in parentheses

${ }^{*} p<0.10,{ }^{* *} p<0.05,{ }^{* * *} p<0.01$ 
VITA

\section{ANGEL ARTURO PACHECO PAREDES}

Born, Puebla, México

2004-2009

Bachelor of Business Administration

Instituto Tecnológico de México

México City, México

2004-2010

Bachelor of Public Accounting and Financial Strategy

Instituto Tecnológico de México

México City, México

2009-2011

Master of Accounting

Florida International University

Miami, Florida

2009-2011

Master of Accounting

Instituto Tecnológico de México

México City, México

2012-2016

Doctoral Candidate

Florida International University

Miami, Florida

\section{PUBLICATIONS AND PRESENTATIONS}

Pacheco, A. and C. Wheatley. 2014. Accruals and Real Earnings Management in the Oil and Gas Industry. Oil, Gas \& Energy Quarterly 63(2): 187-198.

Pacheco, A. and C. Wheatley. August, 2014. The Influence of Culture on Real Earnings Management. Paper presented at the meeting of the American Accounting Association Annual Meeting, Atlanta, Georgia.

Pacheco, A. and C. Wheatley. October, 2014. The Influence of Culture on Real Earnings Management. Paper presented at the meeting of the Academy of International Business Southeast Meeting, Miami, Florida.

Pacheco, A. and C. Wheatley. February, 2015. The Influence of Culture on Real Earnings Management. Paper presented at the meeting of the American Accounting Association International Accounting Section, Palm Springs, California.

Pacheco, A. and C. Wheatley. 2016. The Influence of Culture on Real Earnings Management. International Journal of Emerging Markets. Forthcoming. 